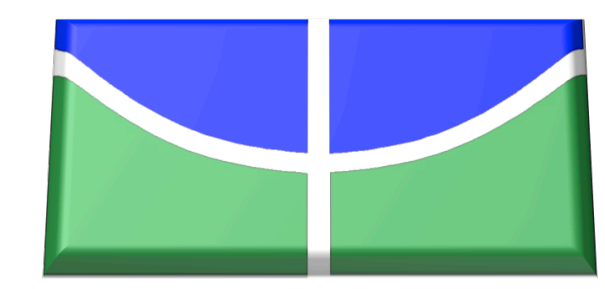

UNIVERSIDADE DE BRASÍLIA - UNB

INSTITUTO DE LETRAS - IL

DEPARTAMENTO DE LÍNGUAS ESTRANGEIRAS E TRADUÇÃO - LET

PROGRAMA DE PÓS-GRADUAÇÃO EM LINGUÍSTICA APLICADA - PPGLA

CURSOS E (PER)CURSOS:

ASPECTOS HISTÓRICOS E POLÍTICOS DO ENSINO DE PLE NA AMÉRICA CENTRAL

FIDEL ARMANDO CAÑAS CHÁVEZ

DISSERTAÇÃO DE MESTRADO EM LINGUÍSTICA APLICADA

BRASÍLIA - DF

FEVEREIRO/2016 


\section{REFERÊNCIA BIBLIOGRÁFICA E CATALOGAÇÃO}

CAÑAS CHÁVEZ, Fidel Armando. Cursos e (per)cursos: aspectos históricos e políticos do ensino de PLE na América Central. Departamento de Línguas Estrangeiras e Tradução, Universidade de Brasília, 2016. Dissertação de mestrado.

FICHA CATALOGRÁFICA ELABORADA PELA BIBLIOTECA CENTRAL DA UNIVERSIDADE DE BRASÍLIA. ACERVO

Documento formal, autorizando reprodução desta dissertação de mestrado para empréstimo ou comercialização, exclusivamente para fins acadêmicos, foi passado pelo autor à universidade de Brasília e acha-se arquivado na secretaria do programa. $\mathrm{O}$ autor reserva para si os outros direitos autorais, de publicação. Nenhuma parte desta dissertação de mestrado pode ser reproduzida sem a autorização por escrito do autor. Citações são estimuladas, desde que citada a fonte.

Cañas Chávez, Fidel Armando

CCC235 Cursos e (per)cursos: aspectos históricos e

cc políticos do ensino de PLE na América Central / Fidel

Armando Cañas Chávez ; orientador Lúcia Maria

Barbosa. -- Brasília, 2016.

$132 \mathrm{p}$.

Dissertação (Mestrado - Mestrado em Linguística Aplicada) -- Universidade de Brasília, 2016.

1. Políticas Linguísticas . 2. História do Ensino de Línguas . 3. Português como Língua Estrangeira (PLE). 4. Difusão da Língua Portuguesa no Exterior. 5. Formação de Professores de PLE. I. Barbosa, Lúcia Maria, orient. II. Título. 
CURSOS E (PER)CURSOS:

\section{ASPECTOS HISTÓRICOS E POLÍTICOS DO ENSINO DE PLE NA AMÉRICA CENTRAL}

Dissertação apresentada ao Departamento de Línguas Estrangeiras e Tradução da Universidade de Brasília, como requisito parcial à obtenção do titulo de mestre em Linguística Aplicada.

Área de concentração: Ensino e Aprendizagem de Língua Estrangeira.

Orientadora: profa ${ }^{\mathrm{a}}$ Dra ${ }^{\mathrm{a}}$. Lúcia Maria de Assunção Barbosa 


\title{
CURSOS E (PER)CURSOS: \\ ASPECTOS HISTÓRICOS E POLÍTICOS DO ENSINO DE PLE NA AMÉRICA CENTRAL
}

\begin{abstract}
Dissertação de mestrado apresentada ao programa de Pós-Graduação em Linguística Aplicada da Universidade de Brasília, como requisito parcial à obtenção do título de Mestre em Linguística Aplicada.
\end{abstract}

\section{APROVADA POR}

Prof $^{\mathrm{a}}$. Dr ${ }^{\mathrm{a}}$. Lúcia Maria de Assunção Barbosa - Universidade de Brasília (UnB) (Orientadora)

Prof $^{\mathrm{a}}$. Dr ${ }^{\mathrm{a}}$. Denise de Paula Martins de Abreu-e-Lima - Universidade Federal de São Carlos (UFSCar)/Ministério da Educação (MEC)

(Examinadora externa)

Prof $^{\mathrm{a}}$. Dr ${ }^{\mathrm{a}}$. Janaína Soares Alves - Universidade de Brasília (UnB)

(Examinadora interna)

Prof $^{\mathrm{a}}$. Dr ${ }^{\mathrm{a}}$. Joselita Júnia Viegas Vidotti - Universidade de Brasília (UnB)

(Examinadora suplente)

Brasília, 11 de fevereiro de 2016 
Um homem precisa viajar. Por sua conta, não por meio de histórias, imagens, livros ou TV. Precisa viajar por si, com seus olhos e pés, para entender o que é seu. Para um dia plantar as suas próprias árvores e dar-lhes valor. Conhecer o frio para desfrutar o calor. E o oposto. Sentir a distância e o desabrigo para estar bem sob o próprio teto. Um homem precisa viajar para lugares que não conhece para quebrar essa arrogância que nos faz ver o mundo como o imaginamos, e não simplesmente como é ou pode ser; que nos faz professores e doutores do que não vimos, quando deveríamos ser alunos, e simplesmente ir e ver.

Amyr Klink, Mar sem fim 


\section{AGRADECIMENTOS}

Concluir o mestrado foi um sonho que começou em El Salvador há mais de um quinquênio. O panorama via-se difícil, mas aconteceu. Todavia, nunca poderei dizer que a conclusão desse sonho foi produto do meu esforço unicamente. Rendo, portanto, meus agradecimentos a todos os que contribuíram para que aquilo que um dia parecia inatingível fosse cristalizado em uma experiência que hei de guardar por toda a minha vida:

A Deus, por me permitir alcançar o que antes se vislumbrava inalcançável.

A minha mãe, Reina Esther Chávez de Cañas, minha guerreira e principal referência de luta, amor, esforço e superação. Obrigado pelo privilégio de ser chamado seu filho e por me ensinar tanto com o exemplo.

A meu pai, Fidel Cañas, às minhas irmãs: Carolina Cañas, Reina Cañas e Esther Cañas, obrigado por cada prece, por cada gesto de carinho e por me incentivarem a correr atrás do meu sonho e por sonharem junto a mim.

A minha amiga e primeira professora de português: Juliana Soto Galindo, por acender a chama da língua portuguesa, "paixão que me chamou ardentemente", no dizer de Clarice Lispector. Agora entendo que um professor de uma língua estrangeira tem a capacidade, no seu exercício profissional, de mudar o rumo da vida de um aprendente.

A Fátima Galindo de Soto, diretora do Centro Cultural Brasil-El Salvador, por ver em mim um potencial professor de uma língua com a qual não nasci, mas com a qual desejo viver; por ser como uma mãe, pelos conselhos, pelo profundo amor demonstrado e pelas conversas que me incentivaram a vir ao Brasil. Obrigado por acreditar em mim, mais do que eu o faço.

A Fidelquino Nascimento, Daniele Silva e Letícia Souza, por serem a primeiras pessoas que me receberam no Brasil.

A Márcia Andrade, por ter sido como uma mãe quando recém cheguei ao Brasil, e pela compaixão e carinho demonstrados até hoje.

A Lousimar Duarte e Célia Rabelo, por terem me acolhido no seu lar durante quase um ano, dando um gosto muito especial de família à minha estada no Brasil.

A Verónica Andrea González, por ser um exemplo de perseverança, luta, e humanidade. Obrigado pelas conversas acadêmicas esclarecedoras e pelos momentos descontraídos. Gracias por ser una hermana para mí. Receba meus agradecimentos e profunda admiração.

Ao pessoal da secretaria do PGLA: Eliane Simão, pela gentileza, carinho e por me incentivar a tentar o mestrado em Brasília, experiência que marcou minha vida para sempre. Cristina Massae, Luna Morena, Rafael Miranda, Nina Canaã, Thiago Pereira e Daniel Arcanjo, agradeço pela amabilidade, amizade e presteza que sempre os caracterizaram. Meu muito obrigado a vocês.

Ao pessoal do Núcleo de Ensino e Pesquisa em Português para Estrangeiros (NEPPE): Verônica Vinecký, Alice Cidade, Ananji Costa, Daniel Freitas, Luan Neves, Erica Flávia, 
Camila Macedo, Fernanda Fachina: agradeço-lhes por me fazerem sentir parte de vocês e pelo privilégio de aprender e me abeberar de vocês.

As pessoas e colegas incríveis que conheci durante os dois anos do mestrado: Ana Gabateli, Isabel Teixeira, Gabriel Nascimento dos Santos, Bernd Renner, Chayanne Sousa, Cristiane Vaz, Ingrid Sinimbu, Ana Lúcia Alouche, Mirelle Amaral, Tatiane Ribeiro: obrigado por ultrapassarem o conceito da amizade e serem pessoas que sempre admirarei e terei como grandes referências acadêmicas e pessoais.

A meus amados amigos em El Salvador: Andi Flores Ayala, Isis Sol Candeias, Jenny Gutiérrez, Ivette Ramírez, Saraí Casco-Díaz, Alejandro Arce, Mauricio Trejo, Keren Marroquín, Ana Lucía Hernández, muito obrigado por cada palavra de ânimo à distância e por me ajudarem a vencer os medos e acreditarem em mim. ;Muchas gracias!

Aos professores da UnB: José Carlos Paes de Almeida Filho, Júnia Vidotti, Augusto Moura Filho, Enrique Huelva Unterbäumen, Dioney Moreira Gomes, por serem exemplos fiéis de profissionalismo, seriedade e ética. Recebam meus agradecimentos.

As professoras da banca examinadora: Prof ${ }^{\mathrm{a}}$. Dr ${ }^{\mathrm{a}}$. Denise de Paula Martins de Abreu-e-Lima, Prof $^{a}$. Dr ${ }^{\mathrm{a}}$. Janaína Soares Alves e Prof ${ }^{\mathrm{a}}$. Dr ${ }^{\mathrm{a}}$. Joselita Júnia Viegas Vidotti, agradeço-lhes por terem aceitado o convite de escutar o que temos a dizer.

A Coordenação de Aperfeiçoamento de Pessoal de Nível Superior (CAPES) pela concessão da bolsa de estudos que me permitiu dedicação exclusiva ao mestrado.

Ao pessoal do Centro Cultural Brasil-El Salvador (CCBES), do Centro Cultural BrasilNicarágua (CCBN), e da Fundação de Cultura, Difusão e Centro de Estudos Brasileiros da Costa Rica (FCDEB), por terem aberto as suas portas e terem dedicado seu tempo para as entrevistas e informações que deram origem a este trabalho.

A Clélio Rosa Lino, pelo grande e imensurável apoio e por ser um modelo importante para as pessoas que estão à sua volta. Obrigado por acreditar em mim e me impulsionar a ser melhor a cada dia.

E, de forma muito especial, agradeço profundamente à minha orientadora e grande referência profissional: Lúcia Maria de Assunção Barbosa. Palavras faltariam para the agradecer por cada gesto e cada palavra de ânimo durante esses dois anos. Agradeço-lhe por se mostrar como uma mulher forte, carinhosa, sábia e por me permitir caminhar ao seu lado e aprender tanto sobre a profissão, sobre a academia e, mais importante, sobre a vida. Rendo meus agradecimentos sinceros, também, à família Barbosa. ¡Gracias a la vida, que (nos) ha dado tanto!

Às mulheres que um dia disseram "sim" à vida e decidiram deixar o Brasil e se transformaram, pelos desígnios da vida, em professoras de português para estrangeiros. Acredito que esse destino honroso estava escrito previamente para adornar mais a vida de vocês.

Recebei esta singela homenagem com genuína deferência que hoje, e sempre, render-vos-ei.

Fidel Armando Cañas Chávez 


\section{RESUMO}

A presente dissertação encontra-se epistemologicamente no campo da Linguística Aplicada ao Ensino de Línguas Estrangeiras, na área de concentração de Formação de Aprendizes e alunos. Metodologicamente, trata-se de um Estudo de Caso coletivo que abrangeu três instituições de ensino de português como língua estrangeira de três países América Central. Essas instituições tiveram ou têm um vínculo direto com o governo brasileiro. Duas delas ainda estão vinculadas à representação diplomática do país em que se encontram e outra foi privatizada no ano 1994. Para realizar a pesquisa, fizemos uma pesquisa in loco com uma permanência em campo de três meses. Estabelecemos contato com mais de 22 pessoas entre professores, administrativos, diretores das instituições nos países referidos. Assim, o corpus da presente pesquisa compõe-se, principalmente, de documentos históricos oficiais brasileiros e 985,25 minutos de entrevistas. Dentre os objetivos da presente dissertação estão: conhecer as ações institucionalizadas do governo brasileiro que têm relação com a promoção linguístico-cultural no exterior, mais especificamente nos países visitados. Em segundo lugar, descrever os traços históricos e atuais do ensino de PLE nesses locais; e, finalmente, analisar quais foram as iniciativas oficiais de formação docente e conhecer qual é a avaliação dos professores e, a partir da análise, oferecer insumos de criação de programas de formação docente para professores de PLE no exterior. Sentimos a necessidade de fazer esta pesquisa para começar a contribuir com as pesquisas históricas e políticas no campo da linguística aplicada, e mostrar criticamente o contexto de ensino de PLE além-fronteiras. Assim sendo, a presente pesquisa enquadra-se na metodologia de viés qualitativo (LÜDKE \& ANDRÉ, 1986; DENZIN \& LINCOLN, 1994, 2006; MOURA FILHO 2005, 2010; CHIZOTTI, 2006), com a postura epistemológica interpretativista (SCHWANDT, 2006). Assim, propusemo-nos a realizar uma pesquisa interdisciplinar. Em primeiro lugar, retomamos o modelo OGEL proposto por Almeida Filho $(1993,2007)$ que afirma que há cinco forças que condicionam o ensino de línguas, dentre elas, a história e as políticas. Nesse sentido, quisemos compreender a história como insumo de entendimento do contexto atual e de ação no presente (HOWATT, 2004; FARGE, 2011; GAY, 1990; BLOCH, 2001; NIETZSCHE, 2005) uma história que se apresenta como um contínuo fluxo, um presente expandido que mantém o interesse acesso do pesquisador (PEREIRA, 2009 e PEREIRA \& MATA, 2012). Por outro lado, consideramos as políticas como grandes ações institucionalizadas que tem influência sobre o status das línguas, no que se refere à sua difusão e promoção. (CALVET, 1996). Assim, os resultados mostram que há pontos positivos na política e nas decisões do Itamaraty, órgão governamental encarregado das relações que o Brasil mantém com o exterior; no entanto, na hora de avaliar o ensino de PLE e a formação docente, vemos que há pontos que pode(riam) ser fortalecidos. Assim, faz-se necessária a criação de uma política que contemple o impacto da difusão da língua e a profissionalização dos docentes em serviço. Apresentamos, também, uma avaliação da formação até agora recebida e insumos para o planejamento de formação de professores de PLE no exterior, partindo do perfil do grupo pesquisado.

Palavras-chave: Políticas linguísticas; História do ensino de línguas; Português como Língua estrangeira, Difusão da língua portuguesa no exterior; Formação de professores de PLE 


\section{RESUMEN}

Este trabajo se ubica epistemológicamente en el campo de la Lingüística Aplicada a la Enseñanza de Lenguas Extranjeras en el área de concentración: Aprendiz Formación y estudiantes. Metodológicamente, se trata de un estudio de caso colectivo. Para tal, fuimos a tres instituciones educativas de portugués como lengua extranjera en tres países centroamericanos. Dos de ellas todavía están vinculadas a la representación diplomática del país. La tercera se privatizó en 1994. Para llevar a cabo la investigación, se realizaron entrevistas en esos países. Establecimos contacto con más de 22 personas, entre profesores, administrativos, directores de las instituciones de esos países. De esta manera, el corpus de esta investigación consiste principalmente en documentos históricos oficiales brasileños y 985.25 minutos de entrevistas en profundidad. Entre los objetivos de esta disertación están: conocer las acciones institucionalizadas del gobierno brasileño que se relacionan con la promoción lingüística y cultural en el extranjero. En segundo lugar, describir las características históricas y actuales de la enseñanza PLE en estos países visitados; y, finalmente, analizar cuáles fueron las iniciativas oficiales de formación de maestros y saben lo que es la evaluación de los docentes y, a partir del análisis, proporcionan insumos para crear programas de formación docente para maestros PLE en el extranjero. Sentimos la necesidad de hacer esta disertación para empezar a contribuir a la investigación histórica y política en el campo de la lingüística aplicada, y mostrando críticamente contexto de enseñanza PLE afuera de las fronteras. Por lo tanto, el presente estudio es parte de la metodología cualitativa (LÜDKE y ANDRÉ, 1986; DENZIN y LINCOLN, 1994, 2006; MOURA FILHO 2005, 2010; CHIZOTTI, 2006), con la postura epistemológica interpretativa (Schwandt, 2006). Nos propusimos a realizar una investigación interdisciplinaria. En primer lugar, retomamos el modelo OGEL propuesto por Almeida Filho $(1993,2007)$, que establece que hay cinco fuerzas que determinan la enseñanza de idiomas, entre ellos, la historia y la política. En este sentido, hemos querido entender la historia como un aporte a la comprensión del contexto actual (Howatt, 2004; FARGE, 2011; GAY, 1990; BLOCH, 2001; NIETZSCHE, 2005), una historia que se presenta como un continuo, un presente ampliado. (PEREIRA, 2009 y PEREIRA Y MATA, 2012). Por otro lado, consideramos que las políticas como las grandes acciones institucionalizadas que tienen influencia en la situación de las lenguas, con respecto a su difusión y promoción. (Calvet, 1996). Por lo tanto, los resultados muestran que hay puntos positivos en la política y las decisiones del Ministerio de Relaciones Exteriores, organismo gubernamental encargado de las relaciones que Brasil mantiene con el exterior; sin embargo, en la evaluación de la enseñanza de formación PLE, vemos que hay puntos que podrían fortalecerse. Por lo tanto, es necesario crear una política que aborde el impacto durador de la difusión de la lengua y la profesionalización de los docentes en servicio. Presentamos, también, una evaluación de la formación que hasta el momento han recibido los professores, así como insumos para la planificación de los profesores de formación PLE en el extranjero, partiendo del perfil de grupo de estudio.

Palabras clave: Políticas Lingüísticas; Historia de la enseñanza de idiomas; Portugués como Lengua Extranjera; Difusión de la lengua portuguesa en el extranjero; Formación de profesores de PLE 


\begin{abstract}
This work is epistemologically in the field of Applied Linguistics to the Teaching of Foreign Languages in the concentration area Apprentice and studens Training. Methodologically, it is a collective Case Study that covered three Portuguese educational institutions as a foreign language in three Central American countries. These institutions had or have a direct link with the Brazilian government. Two of them are still linked to the diplomatic representation of the country and the other one and was privatized in 1994. To do this research, we conducted a survey in three months. We made contact with more than 22 people including teachers, administrative, directors of the institutions in those institutions. Thus, the corpus of this research consists mainly of Brazilian official historical documents and 985.25 minutes of interviews. Among the goals of this thesis are: to know the institutionalized Brazilian government's actions that are related to linguistic and cultural promotion abroad. Second, describe the historical and current features of PLE teaching in these countries visited; and finally analyze what were the official initiatives of teacher training and know what is the assessment of teachers and, from the analysis, provide inputs to create teacher training programs for PLE teachers abroad. We feel the need to do this research to start contributing to the historical and political research in the field of applied linguistics, and critically showing PLE teaching context across borders. Therefore, the present study is part of the qualitative bias methodology (LÜDKE \& ANDRÉ, 1986; DENZIN \& LINCOLN, 1994, 2006; Moura Filho 2005, 2010; CHIZOTTI, 2006), with interpretive epistemological stance (Schwandt, 2006). So we set out to conduct an interdisciplinary research. First, we resumed the OGEL model proposed by Almeida Filho $(1993,2007)$ which states that there are five forces that determine the teaching of languages, among them, the history and policies. In this sense, we wanted to understand history as an input to understanding the current context and action in this (Howatt, 2004; FARGE, 2011; GAY, 1990; BLOCH, 2001; NIETZSCHE, 2005) a story that presents itself as a continuous stream, an expanded gift that keeps interest Access researcher (PEREIRA, 2009 and PEREIRA \& MATA, 2012). On the other hand, we consider policies such as large institutionalized actions that have influence on the status of languages, with respect to its dissemination and promotion. (CALVET, 1996). Thus, the results show that there are positive points in the policy and decisions of the Itamaraty, in charge of relations that Brazil maintains with other countries; however, when evaluating teaching PLE and teacher training, we see that there are points that should be strengthened. Thus, it is necessary to create a policy which addresses the impact of the spread of the language and the professionalization of teachers in service. In this paper, also, we offer a feedback of the training received so far and inputs for planning training PLE teachers abroad, starting from this specific study group profile.
\end{abstract}

Keywords: Language policies; History of language teaching; Portuguese as a Foreign Language; Diffusion of the Portuguese language; PLE teacher training 


\section{LISTA DE IMAGENS}

Imagem 1 Políticas de ensino de LE no conceito de PL p. 35 


\section{LISTA DE TABELAS}

Tabela 1 Produções acadêmicas sobre políticas linguísticas $\quad$ p. 21

Tabela 2 Ações institucionalizadas do governo brasileiro para a promoção e p. 65 linguístico-cultural do Brasil

$\begin{array}{llll}\text { Tabela } 3 \text { Instituições oficiais de difusão linguístico-cultural nos países visitados } & \text { p. } 68\end{array}$

Tabela 4 Perfil dos professores de PLE em El Salvador p.73

$\begin{array}{lll}\text { Tabela } 5 \text { Perfil dos professores de PLE na Nicarágua } & \text { p. } 73\end{array}$

Tabela 6 Avaliação do PROFIC 1 (México DF, México) p. 80

Tabela 7 Avaliação do PROFIC 2 (Manágua, Nicarágua) p. 82

Tabela 8 Avaliação do PROFIC 3 (San Salvador, El Salvador) p. 83

Tabela 9 PEC-G selecionados América Latina e Caribe 2000 a $2015 \quad$ p. 94

Tabela 10 PEC-PG selecionados América Latina e Caribe 2000 a $2013 \quad$ p. 94

Tabela 11 Propostas de formação docente CCBES e CCBN p. 100 


\section{LISTA DE GRÁFICOS}

Gráfico 1 Número de Centros Culturais Brasileiros por continente

p. 69

Gráfico 2 Perfil profissional dos professores de ple nos países visitados

p. 74

Gráfico 3 Inscrições homologadas Celpe-Bras 2009-2015

p. 89

Gráfico 4 Alunos PLE inscritos no primeiro período letivo 2015: CCBES,

p. 90

CCBN, FCDEB 


\section{LISTA DE ABREVIATURAS E SIGLAS}

AELin

CCBES

CCBN

CCBs

CEBs

Celpe-Bras

DC

DPLP

FCDEB

ICs

INEP

MRE

OGEL

PEC-G

PEC-PG

PL

PLE

PROFIC

RBEx

SIPLE

UES

UNICAMP

UNICAP

IsF

PsF
Aprendizagem e Ensino de Línguas Estrangeiras

Centro Cultural Brasil-El Salvador

Centro Cultural Brasil-Nicarágua

Centros Culturais Brasileiros

Centros de Estudos Brasileiros

Certificado de Proficiência em Língua Portuguesa para Estrangeiros

Departamento Cultural do Itamaraty

Divisão de Promoção da Língua Portuguesa

Fundação de Cultura, Difusão e Centro de Estudos Brasileiros da Costa Rica

Institutos Culturais

Instituto Nacional de Estudos e Pesquisas Educacionais Anísio Teixeira

Ministério das Relações Exteriores do Brasil

Operação Global de Ensino de Línguas

Programa de Estudante Convênio de Graduação

Programa de Estudante Convênio de Pós-Graduação

Políticas Linguísticas

Português como Língua Estrangeira

Formação Intensiva Continuada para Professores de Português Língua Estrangeira

Rede Brasileira de Ensino do Exterior

Sociedade Internacional de Português Língua Estrangeira

Universidad Nacional de El Salvador

Universidade Estadual de Campinas

Universidade Católica de Pernambuco

Idioma sem Fronteiras

Português sem Fronteiras 


\section{SUMÁRIO}

1. Introdução 16

$\begin{array}{ll}\text { 1.1. Primeiros passos no percurso e justificativa } & 16\end{array}$

$\begin{array}{ll}\text { 1.2. Objetivos } & 17\end{array}$

$\begin{array}{ll}\text { 1.3. Perguntas de pesquisa } & 18\end{array}$

$\begin{array}{ll}\text { 1.4. Delimitação da pesquisa e estrutura da dissertação } & 18\end{array}$

2. Fundamentação Teórica 19

2.1. O exercício multifacetado do ensino de línguas estrangeiras 20

2.2. O plano das forças $\quad 23$

2.3. A pesquisa histórica na Linguística Aplicada 26

$\begin{array}{ll}\text { 2.3.1. A história: debates e recortes } & 28\end{array}$

2.3.2. História do Tempo Presente 31

2.3.3. O presente: uma possível conceitualização $\quad 33$

2.3.4. Memória e/é história $\quad 34$

2.4. As políticas linguísticas: definição e áreas de ação 35

2.4.1. Políticas linguísticas e políticas de ensino de línguas 36

2.4.2. Soft Power ou DC 41

3. Referencial metodológico 43

3.1. Da inerente necessidade de tomar para si o conhecimento 43

3.2. Pesquisa quantitativa e qualitativa 44

3.3. Estudo de Caso como metodologia de pesquisa 46

3.3.1. Estudo de caso: análise documental 46

3.4. Alguns pressupostos sobre pesquisa histórica 48

3.5. Instrumentos de coleta de registros, tipologia das entrevistas e análise de dados

3.5.1. Entrevistas $\quad 52$

3.5.2. Observação participante 53

3.6. Análise de dados $\quad 54$

3.7. Aspectos éticos da pesquisa $\quad 55$

3.8. Apresentação dos participantes da pesquisa $\quad 56$

4. Análise de registros 60

4.1. A difusão da língua portuguesa brasileira no mundo: um recorte histórico 66

4.2. Perfil dos professores de português na América Central 76

4.3. Formação recebida pelo corpo docente $\quad 80$

4.4. Celpe-Bras e PEC-G/PEC-PG 91

4.5. O alcance dos centros de ensino de PLE nos países visitados 98

$\begin{array}{ll}\text { 4.6. Conclusões Parciais } & 102\end{array}$

5. Considerações finais 107

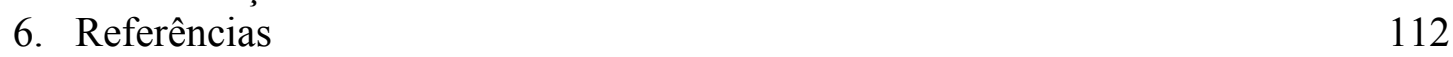

7. Apêndices 119

$\begin{array}{lr}\text { 8. Anexos } & 122\end{array}$ 


\section{INTRODUÇÃO}

\subsection{Primeiros passos no percurso e justificativa}

O Brasil tem dimensões continentais e a língua portuguesa tem alcance mundial. $\mathrm{O}$ lugar do português no espaço das línguas vem sendo discutido nos últimos anos. Silva (1990, p. 18) asseverou na sua pesquisa que a língua portuguesa está no sétimo lugar dentre as línguas mais faladas. O site especializado de pesquisa de línguas Ethnologue publicou no ano 2009 que, mesmo sendo falada por uma parte relativamente pequena da população mundial (apenas 3,1\%), "o português é a quinta língua mais falada no mundo como materna, atrás do chinês, do espanhol, do inglês e do árabe, nessa ordem”. (DA SILVA, 2013, p. 53).

Recentemente, Oliveira (2013, p. 55), afirma que a língua ocupa oficialmente 10,7 milhões de $\mathrm{km}^{2}$ e está presente na América, Europa e Ásia e possui de 221 a 245 milhões de falantes como primeira ou como segunda língua em variados níveis de proficiência. $\mathrm{Na}$ internet, o português alcançou recentemente a cifra de 87 milhões de usuários, passando a ser, em 2010, a quinta língua mais usada na rede (à frente do japonês) número que, segundo o autor, cresce com velocidade moderada.

A posição da língua portuguesa no cenário linguístico atual faz com que haja pessoas interessadas em aprendê-la, estudá-la e nela circular socialmente para propósitos diversos. $\mathrm{O}$ Brasil e Portugal tiveram consciência disso, uma vez que criaram instituições especializadas em difundir a sua língua e cultura. O Brasil, nesse sentido, conta com mais de 75 anos de história de diplomacia cultural por meio da difusão da língua e da cultura brasileira, objetivada em 24 Centros Culturais Brasileiros, 5 Núcleos de Estudos Brasileiros, 40 leitores ativos, 58 postos aplicadores do Exame Celpe-Bras no exterior, e cujo número de avaliados desde a sua primeira aplicação até o ano passado ultrapassa os 14 mil. Ademais, graças aos Programas Estudante Convênio de Graduação e Pós-Graduação, o Brasil conseguiu formar 1939 alunos em cursos de graduação nos últimos 15 anos e 1625 alunos de pós-graduação nos últimos 13 anos ${ }^{1}$.

Apesar de ter essa destacada presença no cenário mundial, Bagno e Carvalho (2015, p. 23) afirmam que o trabalho de difusão linguístico-cultural do Brasil no exterior é tímido, se

\footnotetext{
${ }^{1} \mathrm{O}$ total de alunos vindos unicamente América Latina. O número de alunos total encontra-se no site da Divisão de Temas Educacionais.
} 
comparado aos esforços realizados por Portugal. Dados do Instituto Camões ${ }^{2}$ do ano 2015, informam que o referido instituto está presente em 84 países, tem 19 Centros Culturais Portugueses, 69 Centros de Língua Portuguesa, 47 leitores ativos e mais de 800 professores vinculados a redes de ensino privada e particular ao redor do mundo. Os autores supracitados afirmam, ainda, que é necessário que haja políticas claras de difusão e reconhecimento da importância do português brasileiro e da relevância de uma formação de profissionais do ensino.

Assim, baseados nesses argumentos, os autores acenderam a chama que deu origem a esta pesquisa. Após a minha formatura em comunicação social, fui chamado para dar aulas de português no Centro Cultural Brasil-El Salvador. Durante o exercício docente, questionava o fato de não haver cursos de formação docente. A diretora da instituição dizia-me que os cursos de formação não eram tão frequentes, e que devíamos esperar a aprovação deles.

Ao crescer um vínculo cada dia mais forte entre mim e a língua portuguesa, decidi deixar o meu país e percorrer $5147 \mathrm{~km}$, para me aprofundar nos estudos especializados de pós-graduação no Brasil na área da Linguística Aplicada. Depois de vir e cursar a disciplina Aquisição de Segunda Língua, na condição de aluno especial, decidi pesquisar sobre a realidade do ensino de português como língua estrangeira no meu país, e quis abranger para outros países vizinhos. Decidi fazê-lo pois, ao encontrar literatura especializada na área, percebi que a bibliografia a respeito do ensino de português como língua estrangeira fora do Brasil afirmava que os docentes "que nem sequer buscavam especialização na área de ensino de Português como Língua Estrangeira”. (FERREIRA, 1996).

Eis a gênese do presente trabalho que tentou abranger $201,635 \mathrm{~km}^{2}$ localizados no coração das Américas, mais especificamente, em três países da América Central: El Salvador, a Nicarágua e a Costa Rica, países pequenos se comparados ao Brasil mas com uma ampla e rica história. Para se ter uma ideia, a área delimitada cabe 42 vezes no Brasil e é um pouco menor que o estado de São Paulo.

Assim, a presente dissertação se propõe a mostrar os cursos e percursos do ensino de PLE nos países mencionados baseados em processos históricos e políticos. A escolha do título se deve a vários motivos: primeiro, porque pretendemos esboçar historicamente quais foram as origens e processos do ensino da língua portuguesa, dos professores, das instituições e da institucionalização da difusão linguístico-cultural do Brasil; segundo, o dicionário on-line Priberam, define a palavra curso como "movimento em determinada direção, evolução", e

2 Disponível em: <http://www.instituto-camoes.pt/quem-somos/root/sobre-nos/quem-somos> Acesso em 10/01/2016. 
percurso como "caminho, giro". Assim sendo, o título justifica-se pois pretendemos ver qual é o rumo do ensino de PLE no local visitado e qual foi seu trajeto. Em terceiro lugar, conceitos como evolução, rumo, caminho, despertam em nós emoções, nostalgia, sonhos e esperanças.

\subsection{Objetivos}

Esta pesquisa tem como objetivo esboçar a história do ensino de PLE nos países visitados e, também, conhecer as iniciativas institucionalizadas oficiais do governo brasileiro que têm relação com a promoção e difusão linguístico-cultural no exterior. Nesse trajeto, os objetivos foram sintetizados em dois (02), os quais nortearão a presente dissertação:

1. Conhecer as ações institucionalizadas do governo brasileiro que têm relação com a promoção da língua e cultura brasileira (em perspectiva histórica), mais especificamente na América Central.

2. Analisar as iniciativas oficiais, em uma das frentes de uma política para o PLE, a saber, a da formação docente, conhecer a avaliação dos professores e, a partir da análise, oferecer insumos de criação de programas de formação docente para professores de PLE na região visitada na América Central.

\subsection{Perguntas de pesquisa}

Em consonância com os objetivos anteriores, quisemos construir perguntas que pudessem nos auxiliar na análise e compreensão do fenômeno a ser estudado. Assim sendo, no caminho da construção da dissertação que visa a analisar processos históricos e políticos do ensino de PLE na Costa Rica, em El Salvador e na Nicarágua, buscamos responder às seguintes perguntas:

1. Quais são as ações institucionalizadas do governo brasileiro que guardam relação com a promoção linguístico-cultural na América Central?

2. No tocante a essas políticas para a região, quais são os traços históricos e atuais do ensino de PLE nos três países visitados: El Salvador, Nicarágua e Costa Rica? 
3. Quais as iniciativas oficiais de formação docente e qual a avaliação dos professores dos centros visitados? Quais são as necessidades de formação docente dos professores de PLE nos países visitados?

\subsection{Delimitação da pesquisa e estrutura da dissertação}

A presente dissertação é uma primeira tentativa de esboçar historicamente o processo de ensino de PLE em três países da América Central, tendo como ponto de partida as políticas de difusão linguístico-culturais que o Brasil mantém com esses países. Assim, em um primero momento parto epistemologicamente da grande área da Linguística Aplicada, com o modelo da Operação Global de Ensino de Línguas, OGEL, proposto por Almeida Filho (1993), que afirma ser a visão de conjunto do mundo das ideias sobre aprender e ensinar línguas fruto da influência de grandes forças condicionantes: a história, as políticas, a tradição da prática, a teoria relevante e um código de ética. Este trabalho pretende focar em duas das forças mencionadas, a saber: a história e as políticas. Almeida Filho (op. cit.) afirma que o nome "força" vem da capacidade de condicionar, uma dimensão que pode influenciar todo o processo global de aprender e ensinar línguas através da abordagem, conceito que será definido no capítulo teórico.

Assim, buscamos teorização que pudesse dar suporte a nossa pesquisa. No caso da história, entendemo-la como um processo contínuo, que permite criar laços entre o passado e o presente e questionar, tendo a capacidade de alumbrar a condição atual por meio do conhecimento dos processos que previamente ocorreram. (HOWATT, 2004; NIETZSCHE, 2005; PEREIRA, 2009)

No tocante às políticas, sistematizamo-las como ações do Estado ${ }^{3}$ que têm relação direta com alterações da forma ou do status que as línguas possuem em um determinado contexto, seja para difundi-las ou para seu ensino. (CALVET, 1996; VIDOTTI, 2012; DINIZ, 2012; DE CASTRO, 2013; DA SILVA, 2013). Assim, no capítulo teórico, evidenciar-se-á que um componente dessa política de status, no dizer de Calvet (1996), é a formação de professores. Dado o exposto, mostramos quais foram as iniciativas de formação docente

\footnotetext{
${ }^{3}$ Costumeiramente, e quiçá por semiose, enxergamos políticas como ações do Estado, grandes interlocuções oficiais, mas temos igualmente políticas institucionais, que independem dos governos. Essa é, a nosso ver, uma vertente profícua que precisa ser explorada em futuras pesquisas. Todavia, em se tratando de uma investigação que pretende abrir a discussão de ações bilateirais entre governos, no tocante às políticas de difusão linguísticocultural, focaremos o conceito 'política' no viés de Calvet (1996).
} 
oficiais para os professores de PLE na região pesquisada, assim como uma avaliação dos cursos por parte dos profissionais de ensino dos países visitados.

Finalizamos a presente pesquisa com uma sistematização de propostas de formação sugeridas pelos próprios professores, que são os que estão cumprindo a função de diplomatas culturais, no sentido de Moutinho e Almeida Filho (2015) em contextos nos quais o docente é o elo entre o Brasil e os aprendentes daquele país estrangeiro.

Assim, a presente dissertação divide-se em 5 capítulos. No primeiro, apresentamos um panorama geral do português no mundo, as razões que motivaram a realização da presente pesquisa, os objetivos e perguntas de investigação que a nortearam. No segundo, apresentamos os pressupostos teóricos que embasaram e deram insumos de análise. No terceiro capítulo apresentamos uma síntese do percurso teórico-metodológico para, no capítulo seguinte, apresentar a discussão de dados colhidos in loco. Foram mais de três meses de permanência em campo e mais de 16 horas de entrevistas. Por último, apresentamos as considerações finais no capítulo 5, assim como contribuições, limitações e novos caminhos de pesquisa que a presente dissertação pode(ria) gerar. 


\section{FUNDAMENTAÇÃO TEÓRICA}

No capítulo anterior, foram discutidos os primeiros traços da pesquisa: o tema, a relevância, a justificativa, as perguntas norteadoras e os objetivos da presente dissertação, assim como a sua estrutura. Neste capítulo, apresentamos o embasamento teórico que dará suporte à investigação sobre os traços históricos de ensino de línguas nos países pesquisados e a sua relação com as políticas de ensino do Brasil no que diz respeito à difusão da língua portuguesa além-fronteiras, assim como uma avaliação do ensino PLE nesses países da América Central.

\subsection{O exercício multifacetado do ensino de línguas estrangeiras}

Ferreira (1996) esboçou as condições do ensino de português fora do Brasil nos Centros Culturais Brasileiros ${ }^{4}$ (CCBs). A autora observou que a condição comumente encontrada é a de professores sem formação específica na área maior da linguagem, que nem sequer buscam especialização na área de ensino de Português como Língua Estrangeira. Mais recentemente, autores como Diniz (2012) e De Castro (2013) encontram que há, ainda, lacunas nesse quesito.

Embora o âmago desta dissertação esteja no parágrafo supracitado, como veremos no capítulo de análise de dados, hipotetizamos que a falta de formação especializada dos docentes dos 24 CCBs espalhados pelo mundo, e outras condições atuais, possa provir do esforço de teorização no campo do Ensino de Línguas incluída na área da Linguística Aplicada.

Iniciamos, então, com uma premissa fundante: o processo de aprender e de ensinar uma língua estrangeira (LE) é multifacetado, denso e complexo e possui, a priori, três planos: plano das forças, das ideias e das materialidades (ALMEIDA FILHO, 2010, p. 17-24). Exporei, a seguir, os dois últimos, a fim de focar, posteriormente, no plano das forças, que é o grande eixo teórico da presente pesquisa.

\footnotetext{
${ }^{4}$ Instituições diretamente subordinadas ao Chefe da Missão Diplomática ou repartição consular do Brasil em cada país, constituindo o principal instrumento de execução da política cultural brasileira no exterior.

${ }^{5}$ Esses planos compõem a grande Operação Global de Ensino de Línguas (OGEL), modelo teórico proposto por Almeida Filho (1993). (Vide ANEXO A).
} 
Toda prática em sala de aula é regida pelas concepções que professores e alunos têm sobre o que é ensinar e aprender. Esses conceitos, nem sempre harmônicos, entram em tensão durante o exercício docente in loco e fora dele (VIANA, 1997). Tais concepções nem sempre surgem de uma reflexão vinda de uma teoria relevante ou de processos de formação de primeiros e segundos agentes ${ }^{6}$, mas, sim, de tradições sobre o que é, ou como deve(ria) ser o ensino.

Aprendentes, por outro lado, nutrem concepções sobre como aprender, herdadas da tradição sobre como concebem seu papel no processo de ensino-aprendizagem. Assim sendo, concluímos com as palavras de Almeida Filho (2007, p. 48) que "há uma história de ensinar em cada sociedade, firmemente enraizada em valores compartilhados". À maneira de exemplo, vê-se uma influência de longo alcance da cultura gramatical no Brasil (LUFT, 1984; GERMAIN, 1993; ALMEIDA FILHO, 2011) e da gramática combinada com o confucionismo na China (TING, 1987) no tocante ao ensino de línguas.

Esse conjunto de ideias, suposições e crenças sobre a prática do ensinar e aprender (no nosso caso, línguas estrangeiras) é o que Almeida Filho (1997) define como abordagem, baseado nas teorias de autores como Anthony (1963) e Richards \& Rodgers (1982). Almeida Filho afirma que abordagem é uma filosofia de trabalho, um conjunto de pressupostos explicitados, princípios estabilizados ou mesmo crenças intuitivas quanto a natureza da linguagem humana, de uma língua estrangeira em particular, de aprender e de ensinar línguas, da sala de aula de línguas e de papéis de aluno e de professor de outra língua.

Vale salientar que cada agente do processo de ensino possui uma abordagem e elas entrarão em tensão (ALMEIDA FILHO, 2010). Por exemplo, em uma dada situação real de ensino, um professor que não quisesse ensinar só gramática na escola poderia encontrar a cobrança dos alunos que "pensam que só assim é possível aprender uma língua, pela gramática explícita" ou dos colegas mais antigos, ou dos diretores da instituição educativa que acreditam na gramática, e só nela, como resposta ao ensino de línguas estrangeiras bemsucedido.

O mesmo autor estabelece a abordagem de ensino de um professor como "uma filosofia de ensinar, a uma verdadeira força potencial" que orienta todo o processo de ensino de uma língua estrangeira. Para fins de sistematização, Viana (1997) afirma que, considerando que a abordagem é um elemento crucial para as decisões quanto ao

\footnotetext{
${ }^{6}$ Para Almeida Filho (2011, p. 23), há agentes envolvidos no processo de ensino-aprendizagem de línguas (Aprendentes, $1^{\circ}$ agentes; Professores, $2^{\circ}$ agentes; Instituições, governo, pais de família, parentes, sociedade, sistema educacional, $3^{\circ}$ agentes).
} 
planejamento, ter-se-ão duas diretrizes definindo planejamentos: gramatical ou comunicativo. Fala-se, por conseguinte, em duas macro-abordagens: gramatical (com ênfase no ensino das regras do código linguístico e metalinguagem) e a comunicativa (cuja ênfase é o intercâmbio de sentidos e experiências relevantes/reais para o aprendente). A abordagem, portanto, funciona no plano intangível das ideias, mas comanda o plano tangível do processo de ensinoaprendizagem, este é o das materialidades, que definiremos a seguir.

Baseado na visão que o professor tiver sobre ensinar/aprender/língua estrangeira, assim será o desempenho que vai evidenciar na sala de aula. Para Almeida Filho (2010, p. 23) há quatro materialidades ou concretudes no exercício profissional dos docentes de LE; a saber, o planejamento, a seleção e elaboração de material didático, as experiências em sala de aula e as avaliações. Ou seja, dependendo da abordagem do professor, cada uma dessas materialidades terá influência direta no exercício docente: por exemplo, uma abordagem gramatical pressupõe planejamento com foco na gramática, uma seleção de material gramatical, experiências em sala de aula que tenham como objetivo a prática do código linguístico e, finalmente, avaliações que busquem aferir conhecimentos de metalinguagem.

Assim sendo, a abordagem provém da energia da motivação para ensinar, opera com "matéria-prima" de conhecimentos explícitos e implícitos e se desempenha no ensinar em níveis distintos de competências. Seguindo a proposta teórica de Almeida Filho, Santos (2008, p. 4-5) reafirma pelo menos cinco competências básicas do professor que se desenvolvem durante o período da sua formação e experiência profissional, e são responsáveis pela configuração da sua abordagem, a saber:

\begin{abstract}
1) a competência implícita é a mais básica de todas, e resulta de um conjunto de crenças, intuições e experiências adquiridas pelo professor, e sempre entra em ação na falta de outra; 2) a competência linguístico-comunicativa se refere à capacidade de usar satisfatoriamente a língua que pretende ensinar e, aliada à competência implícita, permite ao professor que se inicie na carreira; 3) a competência teórica é construída a partir do contato do professor com as teorias correntes na área do ensino/aprendizagem de línguas; 4) a competência aplicada consiste na vivência dos conceitos teóricos no dia a dia de sala de aula; 5) a competência-meta corresponde à consciência do professor acerca do seu papel profissional, político e controlador da sua trajetória de crescimento. (SANTOS, 2008, p. 4-5).
\end{abstract}

Estas competências, que têm relação teórica com os aportes de Perrenoud (2000), podem ser desenvolvidas pelo professor através da análise de abordagem e do seu engajamento em atividades de aperfeiçoamento teórico ${ }^{7}$. Acreditamos que se faz necessário

\footnotetext{
${ }^{7}$ Para uma leitura mais aprofundada a respeito, vide ALMEIDA FILHO, J. C. P. de (Org.) O Professor de Língua Estrangeira em Formação. Campinas: Pontes Editores, 2009.
} 
conhecer as distintas competências para, depois, dar um melhor panorama da situação dos profissionais do ensino de PLE nos países visitados na América Central.

\subsection{O plano das forças externas que incidem sobre a abordagem}

Apesar de a abordagem ser a força motriz do processo de ensino dos professores, há forças de fora que intervêm na construção da filosofia de ensino dos professores. Para Almeida Filho (2014), há cinco forças/dimensões/fatores que influenciam/condicionam a abordagem e, por conseguinte, todo o processo de ensino-aprendizagem de línguas, a saber:

1. História do Ensino de Línguas (vivenciada e/ou estudada)

2. Tradição: crenças, memória e intuições que fazem a prática.

3. Teoria adequada para os processos de ensinar e aprender (teoria com T maiúsculo, proveniente da comunidade científica da área e encontrável em revistas, congressos, publicações, etc.).

4. Código de ética que eleva a qualidade das relações na profissão.

5. Políticas de Ensino (estímulo a certas ações e condições do trabalho profissional nas escolas e instituições. Pode ser local, nacional e regional).

No âmbito da Linguística Aplicada, essas forças, fundamentais para a nossa compreensão do processo de ensino e aprendizagem de línguas, estão começando a mostrar sinais de interesse de pesquisadores e teóricos consolidados na nossa área acadêmica. A maneira de exemplo, destacamos, na força da Teoria, o trabalho de Freitas (2013) no Programa de Pós-Graduação em Linguística Aplicada da Universidade de Brasília (PGLA/UnB), seminal em sua natureza, ao apresentar uma meta-análise dos estudos de pesquisadores brasileiros sobre o construto de abordagem.

A autora afirma que a agenda acadêmica brasileira possui uma "fertilidade admirável nessa linha de pesquisa no país desde o final dos anos 80 do século XX”. (FREITAS, 2013, p. 75). A pesquisadora chama a atenção para o fato de que a teoria, segundo ela, substancial e relevante, deve chegar aos professores em serviço e em formação para que possa suprir as necessidades que a prática profissional demanda.

Por outro lado, no que diz respeito ao Código de ética, o trabalho de Barbosa (2014) no círculo de pesquisa aplicada da $\mathrm{UnB}$, pode ser considerado como um primeiro grande passo nas pesquisas relacionadas a essa força, pois gerou a primeira tentativa significativa de criação de um código de normas, direitos e deveres dos professores de línguas. Em palavras da autora, é uma investigação: 
Voltada para o aperfeiçoamento profissional de professores de línguas. Facultou inicialmente a análise de códigos de éticas existentes em outras profissões, bem como as tentativas de criação de um código de ética para professores de modo geral, (a dissertação) avaliou a importância de um código de ética para o enriquecimento e valorização profissional, levantou insumos para a formulação de uma minuta de código de ética para os professores da Área de Ensino e Aprendizagem de Línguas filiada à Linguística Aplicada". (BARBOSA, 2014, p. x).

No que concerne às Políticas linguísticas, constatamos que corre neste momento um crescimento notável na produção acadêmica desde os anos 80. Assim sendo, De Castro (2013, p. 20) afirma que mais de $80 \%$ das teses e dissertações foram defendidas desde 2008 , "o que reforça a relevância do tema no Brasil", em palavras do autor. O autor chama a atenção para o fato de que este tipo de produção acadêmica era até recentemente registrada ainda que exiguamente, na região sul e em São Paulo, o que mostra

\begin{abstract}
uma concentração regional na exploração do assunto, certamente devido a fatores históricos (grande contingente de imigrantes nesta região desde os séculos XIX e $\mathrm{XX}$ ) e geográficos (grande proximidade com países como Argentina, Paraguai e Uruguai). Talvez também por esta última razão, três dessas pesquisas se dediquem ao espanhol, duas ao inglês, uma ao italiano, quatro às línguas estrangeiras modernas em geral e somente uma ao PLE: a tese "Política Linguística do Estado brasileiro na contemporaneidade: A institucionalização de mecanismos de promoção da língua nacional no exterior", de Diniz (2012) defendida no Instituto de Estudos da Linguagem (IEL), da Universidade Estadual de Campinas (UNICAMP). Encontrei ainda as dissertações de mestrado de Diniz (2008) intitulada "Mercado de Línguas: A instrumentalização brasileira do português língua estrangeira" e de Ferreira (1996) intitulada "O Processo de Ensino/Aprendizagem do Português Língua Estrangeira no contexto do MERCOSUL”, ambas com dados de interesse para a questão das politicas para o ensino/aprendizagem da língua". (DE CASTRO, 2013, p. 20)
\end{abstract}

Segundo o autor, só três dissertações abordam o tema de políticas de ensino de PLE, o que é evidência da urgência de mais pesquisas sobre o assunto. Por tanto, contando com o trabalho de De Castro (2013) e este que relato nesta dissertação totalizam cinco produções de teses/dissertações sobre o tema supracitado ${ }^{8}$.

Apresento, a seguir, uma tabela resumo feita por De Castro (2013, p.132) das dissertações produzidas no que diz respeito às políticas de ensino de LE feitas no Brasil. E acrescentamos, no final, a dissertação por ele defendida.

TABELA 1: Produções acadêmicas sobre políticas linguísticas

\begin{tabular}{|l|c|c|}
\hline \multicolumn{1}{|c|}{ Título da Dissertação ou Tese } & Nome do(a) Autor(a) & Local e ano de defesa \\
\hline $\begin{array}{l}\text { Construção multicultural: } \\
\text { Reflexões sobre políticas } \\
\text { alternativas para o ensino de língua }\end{array}$ & Kátia Costa dos Santos & USP (SP), 2002 \\
\hline
\end{tabular}

\footnotetext{
${ }^{8}$ No Programa de Pós-Graduação em Aplicada da UnB há três trabalhos em andamento.
} 


\begin{tabular}{|c|c|c|}
\hline estrangeira (tese) & & \\
\hline $\begin{array}{l}\text { Políticas de ensino de línguas } \\
\text { estrangeiras em escolas públicas do } \\
\text { estado de São Paulo (dissertação) }\end{array}$ & Ênio de Oliveira & UNICAMP (SP), 2003 \\
\hline $\begin{array}{l}\text { Política linguística implícita na } \\
\text { virada do século XXI - O } \\
\text { Programa Nacional do Livro } \\
\text { Didático (dissertação) }\end{array}$ & Tayana de Alencar Tormena & $\begin{array}{c}\text { Universidade de Caxias do } \\
\text { Sul (RS), } 2008\end{array}$ \\
\hline $\begin{array}{l}\text { Políticas e práticas linguísticas: um } \\
\text { estudo sobre o ensino do espanhol } \\
\text { em contexto multilíngue no Paraná } \\
\text { (doutorado) }\end{array}$ & Cibele Krause Lemke & USP (SP), 2010 \\
\hline $\begin{array}{l}\text { Políticas de línguas estrangeiras na } \\
\text { educação básica: Brasil e Argentina } \\
\text { entre avanços, percalços (tese) }\end{array}$ & Maria Silvia Cristofoli & UFRGS (RS), 2010 \\
\hline $\begin{array}{l}\text { As vozes de uma política de ensino } \\
\text { de L.E.M. na educação básica do } \\
\text { estado do PR (dissertação) }\end{array}$ & Jonathas de Paula Chaguri & $\begin{array}{l}\text { Universidade Estadual de } \\
\text { Maringá (PR), } 2010\end{array}$ \\
\hline $\begin{array}{l}\text { Política linguística e ensino de } \\
\text { línguas no SCMB: Enunciados } \\
\text { sobre a implantação do espanhol } \\
\text { anterior à lei 11.161/05 } \\
\text { (dissertação) }\end{array}$ & Lucélio Jantuta & $\begin{array}{l}\text { Universidade Federal de } \\
\text { Santa Maria (RS), } 2010\end{array}$ \\
\hline $\begin{array}{l}\text { Políticas e planejamento do ensino } \\
\text { médio (integrado ao técnico) e da } \\
\text { língua estrangeira (inglês): na } \\
\text { mira(gem) da politecnia e da } \\
\text { integração (tese) }\end{array}$ & Daniella de Souza Bezerra & USP (SP), 2012 \\
\hline $\begin{array}{l}\text { Políticas linguísticas para o ensino } \\
\text { de língua estrangeira no Brasil do } \\
\text { século XIX, com ênfase na língua } \\
\text { inglesa (tese) }\end{array}$ & Joselita Júnia Viegas Vidotti & USP (SP), 2012 \\
\hline $\begin{array}{l}\text { Política linguística do Estado } \\
\text { brasileiro na contemporaneidade: a } \\
\text { institucionalização de mecanismos } \\
\text { de promoção da língua nacional no } \\
\text { exterior (tese) }\end{array}$ & $\begin{array}{c}\text { Leandro Rodrigues Alves } \\
\text { Diniz }\end{array}$ & UNICAMP (SP), 2012 \\
\hline $\begin{array}{l}\text { História do futuro: Diagnóstico e } \\
\text { perspectivas de políticas públicas } \\
\text { para o ensino/aprendizagem de } \\
\text { PLE-PL2 no Brasil do século XXI }\end{array}$ & Francisco Tomé de Castro Neto & UnB (DF), 2013 \\
\hline $\begin{array}{llr}\text { O } & \text { Processo } & \text { de } \\
\text { Ensino/Aprendizagem } & \text { de } \\
\text { Português Língua/Estrangeira } & \text { no } \\
\text { contexto do } & \text { Mercosul. (Uma } \\
\text { análise da } & \text { abordagem } & \text { e } \\
\text { metodologia). } & & \end{array}$ & Itacira Araújo Ferreira & UNICAMP (Campinas, SP), 1996 \\
\hline
\end{tabular}

Fonte: De Castro (2013) adaptação nossa.

Após destacarmos parte da produção que há no Brasil no que tange às políticas, sinalizamos a importância de mais produções acadêmicas nas universidades brasileiras sobre história, políticas, e ética, que são as forças externas que condicionam a abordagem e, por conseguinte, toda a operação global de ensino de línguas e, por conseguinte, de PLE, que é o foco da nossa pesquisa. 
Conforme já exposto partindo do título desta dissertação, focalizaremos em duas das forças mencionadas: a saber, a História e as Políticas. Sistematizaremos o referencial teórico de cada força mencionada. Como premissa inicial, concordamos com Schmidt (2006, p. 95) que assevera que o termo teorizar vem da filosofia grega, mais especificamente da filosofia platônica e aristotélica, e cujo significado originou-se de: "ver", "colocar em perspectiva" e "ser espectador partindo de um ponto". A seguir, então, traçamos o percurso da nossa perspectiva baseando-nos no que já foi dito a respeito da história do ensino de línguas e das políticas linguísticas, transitando na nossa área da Linguística Aplicada e abeberando-nos de teorias vindas das ciências sociais, como a história, o que fez o nosso estudo de natureza interdisciplinar.

\subsection{A pesquisa histórica na Linguística Aplicada}

Para Alencar (2009) por meio da história somos capazes de interpretar velhos episódios para descobrir, explorar e projetar novos sentidos que possam produzir perspectivas e atitudes que sejam relevantes na nossa formação e atuação. A autora diz que a história diz muito sobre a nossa identidade, crenças e também sobre o modo como justificamos nossa prática profissional. Portanto, para Alencar (2009), “o ensino de línguas é visto e resolvido em vários momentos da nossa história". Somado às conclusões da autora, Almeida Filho (s/d, p. 2) declara que não há por que dissociar a história geral do Brasil com a história do ensino de línguas: "o conhecimento da história geral do Brasil é favorável ao estudo de história do ensino de línguas do país", afirma o autor.

Por outro lado, cabe o questionamento se a História do Ensino de Línguas tem alguma relação com o nosso objeto de estudo como linguistas aplicados: a Aprendizagem e Ensino de Línguas Estrangeiras (Doravante AELin). Para Almeida Filho (s/d p, 3), sim. Segundo o teórico, a primeira é uma subárea de estudos da segunda. Lima \& Bertoletti (s/d, p.2), preocupados com o anterior exposto, veem uma necessidade preeminente na pesquisa histórica no ensino de línguas. Para os autores, no bojo das pesquisas educacionais de fundo histórico, tem crescido o interesse, nos últimos anos, por um campo de estudos que pretende investigar as mudanças ocorridas, numa determinada área do saber. Trata-se de um conjunto de conhecimentos que, vinculados à escola, propiciam novas relações de saber por meio das ações dos seus agentes principais: professores e alunos.

No que concerne às pesquisas feitas no Brasil sobre a história do ensino de línguas, destacamos os trabalhos significativos de Alexis (2008), que abordou a história do ensino de 
Português Língua Estrangeira na Costa de Marfim, Oliveira (2006) e Vidotti (2012) que trabalharam sobre o ensino de língua inglesa no século XIX e Batista (2014), que tentou abranger o ensino de Português como Língua Materna (PL1) desde os 1500 até os dias atuais.

Os autores supracitados estabelecem que a produção científica sobre a história do ensino de línguas evidencia que tudo o que contemporaneamente permeia o fazer pedagógico tem raízes históricas. Todos chegam à conclusão que, na atualidade, existe uma demanda proeminente e clara pela pesquisa de ensino de línguas de cunho histórico. Retomo o argumento dos autores como uma justificativa fundante da pesquisa por mim desenvolvida.

Há autores que ressaltam um certo descaso na pesquisa histórica no campo da Linguística Aplicada. Por exemplo, Lima \& Bertoletti (s/d, p. 3) afirmam que há uma destruição que impõe a toda sociedade atual e, especialmente, a quem se propõe ao estudo da pesquisa histórica. "O combate ao esquecimento e a promoção da preservação da memória coletiva é tarefa que compete ao historiador". Os argumentos dos autores são similares aos de Hobsbawm (1995, p. 13), ao afirmar que:

\begin{abstract}
A destruição do passado, ou melhor, dos mecanismos que vinculam a nossa experiência pessoal à das gerações passadas, é um dos fenômenos mais característicos e lúgubres do final do século XX. Quase todos os jovens de hoje crescem em uma espécie de presente contínuo, sem qualquer relação orgânica como passado público da época em que vivem, por isso, os historiadores cujo ofício é lembrar o que os outros esquecem, tornam-se mais importantes que nunca no final do segundo milênio.
\end{abstract}

Parece-nos que, na pesquisa histórica, faz-se necessário que exista um vínculo entre pessoas e tempos. Assim, dois elementos são fundamentais ao estudo da História: o caráter humano que ela possui e as relações que o passado e o presente mantêm entre si. Bloch (2001, p. 65) estabelece que: "a incompreensão do presente nasce da ignorância do passado". O autor ressalta, também, que não é válido conhecer o passado se nada se souber acerca do presente. Tratarei sobre isso de forma detalhada mais adiante.

Sobre o conhecimento do passado, Almeida Filho (s/d, p. 1) afirma que é necessário explorar as origens e também as ideias que influenciaram diacronicamente o desenvolvimento do ensino de línguas em um país (ou países) para que ele possa ser, pelo menos em parte, explicado como é hoje.

Howatt (2004, p.1) afirma que um dos propósitos de se conhecer a história do ensino de línguas é tentar explorar suas origens e algumas ideias que o influenciaram e o moldaram ao longo dos anos para, assim, termos ferramentas para explicar por que é assim hoje em dia; ou em palavras de Farge (2011, p. 13), criar um diálogo entre o passado e o presente: “o 
trabalho do historiador é dar a uma sociedade sua memória, seus laços com seu passado a fim de que possa viver melhor com seu presente".

Outro propósito é, ainda, segundo Howatt (2004, p. 1) saber que, assim como outras atividades importantes do ser humano, o ensino de línguas pertenceu a inúmeros contextos, os quais devem ser analisados e, acrescento, interpretados, questionados e pesquisados.

Todavia, toda pesquisa histórica deve ter fins aplicáveis à nossa realidade, e essa aplicabilidade (ou serviço à vida, no dizer de Nietzsche) será discutida mais adiante. Almeida Filho (mimeo, 2015) afirma que um terceiro propósito é constituir uma competência profissional reflexiva por meio de uma formação adequada de novos profissionais ou de aperfeiçoamento de quadros já em exercício. Esses fins pode(riam) impulsionar a pesquisa de natureza histórica no ensino de línguas: de conhecimento, análise e interpretação para movimentar o exercício atual dos professores em serviço profissional. Na seguinte seção, descreveremos os conceitos, relevância e desafios no percurso da investigação de cunho histórico.

\subsubsection{A história: debates e recortes}

Le Goff (1994, p. 17) alega que a história não é uma ciência como as outras "sem contar com aqueles que não a consideram com tal", afirma. Segundo o autor, falar de história é uma façanha nada fácil, mas estas dificuldades de linguagem introduzem-nos no próprio âmago das ambiguidades da história.

Etimologicamente, o autor afirma que a palavra história, após a passagem do tempo e derivada de outras línguas, define-se como histor: "aquele que vê". Esta concepção da visão como fonte essencial de conhecimento leva-nos à ideia que "aquele que vê" é também "aquele que sabe"; historien, em grego antigo, é "procurar saber", "informar-se". Historie significa, pois, "procurar". Ver, logo saber, é um primeiro problema. O teórico afirma também que nas línguas românicas (e em outras), história exprime três sentidos:

1. Procura de ações realizadas pelos homens

2. O objeto de procura é o que os homens realizaram

3. Narração

Nesse sentido, autores como Le Goff (1994) e Bloch (2001) reconhecem dois atuantes principais no cenário de interesse: os homens [como seres que dinamizam o(s) processo(s) 
histórico(s)] e o tempo que é, por natureza, um continuum e também perpétua mudança. De acordo com as ideias de Bloch (2001, p. 55), a história é uma ciência dos homens, ao longo do tempo. O historiador não analisa, apenas, o fator humano. Para o autor, a atmosfera em que seu pensamento respira naturalmente é a categoria de duração. Por outro lado, Veyne (2014, p. 68) afirma que a história é uma noção livresca e não existencial; ela é a organização, por meio da inteligência, de dados que se referem a uma temporalidade.

Le Goff (1994, p. 17) alega que a história não é uma ciência como as outras, "sem contar com aqueles que não a consideram com tal". Nesse sentido, existe o debate também sobre a natureza epistêmica da história, pois, por exemplo, discute-se se é uma ciência ou uma arte pertencente à literatura. Para Farge (2011, p. 68), "a literatura e a história não estão em competição em face desses problemas”. Para a autora, são dois gêneros narrativos que não se confundem, não se anulam e têm necessidade um do outro. Há autores que afirmam que uma união entre ambos os gêneros é uma degradação da história. Por exemplo, Ariès (2013, p. 60) afirma que existe um poder de atração entre os dos gêneros, o que prova, na história, um "poder de contágio". O autor chama essa aproximação, que eclodiu durante o período entreguerras, de bastarda: a história romanceada, vulgarizada, sem seriedade.

Por outro lado, poder-se-ia afirmar, como o fizera Michel de Certeau (apud Farge, 2011, p. 70), em uma interpretação do debate acima exposto: “o historiador é o poeta do detalhe. Sua escritura deve se obstinar em religar os seres e as palavras, em reconhecer a inscrição simbólica na cidade". Essa inscrição simbólica é definida por Rèmond (1974, p. 16) como causas preexistentes, engrenagens, mecanismos que urge desmontar. Gay (1990, p.18) consoante com de Certeau, estabelece que "o historiador é um escritor profissional e um leitor profissional. Como escritor, sofre a pressão de se tornar estilista mantendo-se cientista; cabelhe proporcionar prazer sem comprometer a verdade".

Outro debate sobre a história da história (ou historicizar) é sobre o seu objetivo na vida social das pessoas, ou o que podemos aprender com a história. Para Gumbrecht (1999, p. 460), depois de 1500:

a concepção do tempo como um agente necessário da mudança começou a solapar a validade dos 'exemplos' históricos, cuja famosa aplicabilidade tinha dependido da premissa (geralmente não formulada) de que as implicações, estruturas e funções do comportamento e das ações humanas só foram levemente influenciados, se é que o foram, por seus contextos específicos. A Querela dos Antigos e dos Modernos, que abarcou o final do século XVII e o começo do século XVIII, foi canonizada como o acontecimento intelectual que, no final das contas, invalidou (para nossa mente não histórica) a construção medieval da história. Pela primeira vez, períodos e culturas eram vistos como incomensuráveis, e as pessoas começaram a perguntar se era possível aprender alguma coisa com a história. A resposta a essa pergunta - a saída 
para a primeira crise moderna do aprendizado histórico - foi o que nós ainda chamamos de "filosofia da história". Ela transformou as estruturas do conhecimento sobre o passado, de uma coleção de histórias isoladas (ou “exemplos") para a imagem totalizante da história como um movimento que transformaria continuamente as condições estruturais da ação humana. Portanto, aprender com a história não poderia mais se basear na permanência destas estruturas, nem poderia mais consistir na mera transposição de padrões de comportamento do passado para o presente. (GUMBRECHT, 1999, p. 460).

Para o autor, o conhecimento histórico começou a se definir como a possibilidade de prever as direções que a história, como um movimento progressivo e abrangente de mudança, tomaria no futuro. Em outras palavras, a "filosofia da história" afirmava estreitar o horizonte da alteridade através da qual se esperava que o futuro se tornaria diferente do passado, ou, em outras palavras, "a vida cotidiana de mais da metade da população mundial se tornou dependente da tese de que era possível extrapolar as 'leis' da mudança futura a partir da observação sistemática das mudanças do passado", (GUMBRECHT, p. 461). Essa ideia entrou em colapso com a crise de 1989, na qual evidenciou-se que o conhecimento do passado não pode(ria) prever o futuro.

O historicismo contemporâneo, segundo o autor supracitado, resume-se na característica de as sociedades contemporâneas quererem prever o futuro: "os esforços para descrever o futuro através da 'indução' do passado e do presente são crescentemente substituídos pelo cálculo de riscos - uma atividade cujo primeiro princípio é a imprevisibilidade do futuro" (GUMBRECHT, p. 462). O autor, conclui que devemos cortar definitivamente com a concepção de "aprender com a história". Só assim, afirma, seremos obrigados a pensar seriamente sobre maneiras diferentes de usarmos o nosso conhecimento histórico.

Assim, achamos necessário desdobrar o uso do conhecimento histórico que o autor argumenta. Na mesma discussão, Nietzsche (2005, p. 81) já definira o objetivo expressivo da utilidade da história: devemos estudar a história com o fim de servir à vida. O filósofo alemão reconhece a cientificidade da história (Geisteswissenschaften) e, no entanto, critica a produção de conhecimento pelo próprio conhecimento, uma espécie de dadaísmo científico da história: “o excesso de história mata o homem". (NIETZSCHE, 2005 p. 75). Portanto, uma crítica do autor é que a historiografia poderia estar beatificando o passado e, com isso, não há rumo nenhum ao futuro. Nabuco $(2007$, p. 1) faz a seguinte leitura sobre as ideias do filósofo:

O autor (Nietzche), pois, demonstra como o excesso de conhecimento que originou diversas ciências, inclusive a História, pôde levar o ser humano àquilo que ele chama "febre histórica". É neste contexto que Nietzsche formula suas críticas à 
modernidade e destaca que devemos ter um esquecimento produtivo como forma de escapar a esta doença histórica e vivermos com felicidade".

Na medida em que está a serviço da vida, a história está a serviço de uma força $a$ histórica (como Nietzsche define: ver o passado e conseguir seguir em frente; é o que Foucault (1979) definira como história efetiva): portanto, ela não poderia, nem deveria, jamais se tornar, nessa hierarquia, uma ciência pura, como a matemática (Naturwissenschaften).

\subsubsection{História do Tempo Presente}

Consideramos que, para o melhor entendimento e desenvolvimento da pesquisa sobre a história do ensino de português em El Salvador, na Nicarágua e na Costa Rica, uma vez que é um recorte histórico sobre uma instituição ainda existente e cujos protagonistas ainda exercem a profissão da docência, procuramos articular as questões históricas com alguns pressupostos que orientam a História do Tempo Presente Francesa (doravante HTP).

Para esboçar as origens, alguns historiadores como Burke (2011, p. 17) chamam a HTP, também, de "nova história" e afirmam está associada a Lucien Febvre e a Marc Bloch, que fundaram a revista Annales em 1929 para divulgar a sua abordagem: "não seria difícil negar a importância do movimento para a renovação da história, liderado por esses homens". Para o autor, outros historiadores estavam abandonando os paradigmas tradicionais, como Namier e Tawney na Grã Bretanha de 1930 e Lampert, na Alemanha, três décadas antes deles. Essa separação dos cânones deu origem a uma expressão, para Burke, desdenhosa, que é historie événementielle, "história centrada nos acontecimentos", que foi acunhada nessa ocasião uma geração antes de Bloch e Febvre. "Expressa as ideias de um grupo de estudiosos concentrados em torno do grande sociólogo francês Emile Durkheim e sua revista Année Sociologique, publicação que ajudou a inspirar os Annales. (BURKE, 2011, p. 17).

Além de a HTP ser desenhada, Pereira (2009, p. 22), esclarece detalhadamente outro debate sobre a natureza epistêmica da HTP: é história ou jornalismo? A desconfiança dos historiadores em relação ao jornalismo e, principalmente, em relação à "tirania da atualidade", surgiu em priscas eras. Michelet (apud BLOCH, 2001, p. 36) afirmava que "todo aquele que se ativer ao presente, ao atual, não compreenderá o atual”.

Para contestar o argumento de Michelet, Pereira (2009, p. 22) levanta o seguinte questionamento: “será que os fatos próximos de nós não podem ser estudados com serenidade 
ou objetividade?". O autor recorre a Marc Bloch, que propôs a dialética de compreender o passado pelo presente e o presente pelo passado:

\begin{abstract}
Conhecer a história às avessas, pelo método regressivo, permitiria ao historiador não se perder na obsessão pelas origens. Ao mesmo tempo, a ciência dos homens no tempo teria que vincular o "estudo dos mortos" com os vivos; a ignorância do passado compromete no presente a própria ação. Nesse sentido, o desconhecimento do presente nasce também da ignorância do passado. Porém, de nada adianta compreender e explicar o passado se nada sabemos do presente. Afinal, nesta faculdade de apreensão do que é vivo é que reside, efetivamente, a qualidade fundamental do historiador.
\end{abstract}

Nesse sentido, Vesentini (1997, p.15) afirma: "não é possível esquecer que a presente sociedade resultou, entre outros desdobramentos, daquelas práticas passadas". Somada a essa relação dialética, deve dar-se uma explanação, então, sobre deve ser entendido o presente. A maneira em como entendemos e interpretamos o tempo tem sido amplamente discutida por várias ciências como a antropologia linguística, a qual descreve que há línguas/culturas como a Aymara, Trique, Maori, e o Grego Antigo que interpretam o passado de forma diferente da visão ocidental: o passado está adiante (pois nos é conhecido) e o futuro (desconhecido) atrás de nós. (KÖVECSES, 2005, p. 71).

Segundo Glezer (2007, p. 24), para a sociedade ocidental contemporânea, herdeira laicizada da sociedade europeia cristã, a concepção de tempo dominante é linear progressiva, com passado, presente e futuro. O sentido da história, para a autora, como trajetória da humanidade, é dado pelo futuro, cuja realização consolida a trajetória realizada, quer seja na direção do Juízo Final (na versão religiosa) quer na concretização do Progresso, Desenvolvimento Material ou da Revolução na versão laica (vide também POMIAN, 1993; ARIÈS, 2013).

Destarte, a história teve, outrossim, debates sobre o tempo (VEYNE, 2014, p. 71). Pereira e Mata (2012, p. 9) afirmam que a última década do século passado e a primeira do século XXI foram marcadas por uma obsessão: as reflexões sobre a temporalidade: "fomos seduzidos não só pela memória, mas também pela suposta "crise" da temporalidade moderna. Foram tempos de pós-tudo e de muitos fins, anunciados ou reais”. Os autores começam um questionamento sobre até onde abrangeria o presente e dão uma primeira solução, ao afirmar que é "o passado que não passa é ainda presente".

Os autores questionam se esse "passado que não passa" pode ser, intrinsecamente, contemporâneo. Para dar uma possível resposta sobre o anterior exposto, filio-me aos argumentos de Glezer (2007, p. 23-25) quando afirma que "a história é configurada no 
momento em que é construída, sempre no presente, determinada pelos problemas e condições socioculturais do conhecimento na/da sociedade em que se insere". A autora afirma, ainda:

É o presente que direciona o conhecimento histórico, pois é sempre do momento vivido que surgem as questões para o conhecimento de determinado aspecto do passado. É nas angústias e necessidades da sociedade que o historiador encontra o elemento inicial de seu trabalho - as suas hipóteses orientadoras. A história é construção de conhecimento sobre uma questão perturbadora do presente, que analisa o passado para explicar, compreender ou interpretar o fenômeno em questão".

\subsubsection{O presente: uma possível conceituação}

Pereira \& Mata (2012, p. 14) afirmam que graças ao trabalho de Henri Bergson tem-se a distinção pioneira entre "tempo" e "duração", e, sobretudo, uma solução sofisticada para o problema do "presente". Bergson, para os autores, reconheceu a impossibilidade de chegar a uma definição substantiva do "presente". Trata-se de "uma pura abstração, uma visão do espírito", sem qualquer "existência real". Bergson (apud PEREIRA \& MATA, 2012, p. 15) afirmara que:

a distinção que fazemos entre o nosso presente e o nosso passado é [...] se não arbitrária, pelo menos relativa à extensão do campo que nossa atenção à vida pode abarcar. Numa palavra, nosso presente cai no passado quando deixamos de lhe atribuir um interesse atual. Ocorre com o presente dos indivíduos o mesmo que com o das nações: um acontecimento pertence ao passado e entra para a história quando não interessa mais diretamente à política do dia e pode ser negligenciado [...]. Enquanto sua ação se fizer sentir, ele adere à vida da nação e permanece presente para esta.

E os autores ainda afirmam:

Desenvolvendo um pouco mais o mesmo argumento, o filósofo Hermann Lübbe entende o "presente" como "aquele conjunto de experiências que não se tornaram ainda uma alteridade para nós". Somente quando se produz um "estranhamento" em relação a dados bens de cultura de que dispusemos um dia, ou ainda a vivências pessoais ou coletivas, é que tais coisas se tornam "passado". O simples fato de algo ser pretérito não basta para que o consideremos "passado". Haverá presente enquanto estiverem ativos determinados interesses de presentificação do passado. Lübbe (apud PEREIRA \& MATA, 2012, p. 15).

Portanto, os autores concluem que os eventos já ocorridos são um "presente” para nós pelo tempo em que nosso interesse por eles estiver aceso. Esse interesse pelo presente expandido, por colocarmos um termo, foi refletido por alguns teóricos que afirmavam que o 
presente está se tornando mais lento ou, dilatando: "as estruturas centrais de nosso mundo se transformam agora mais lentamente do que até pouco tempo". (GUMBRECHT, 2010, p. 45).

Assim, tendo em conta que pretendemos esboçar historicamente mais de duas décadas de ensino de português na América Central, e que esse período possui relação indissolúvel e acesa com os dias de hoje, estabelecemos que o período da década dos anos 80 até os dias atuais, é um passado que se faz presente.

A esse respeito, Ricoeur (apud PEREIRA, 2009, p. 25) estabelece uma distinção entre tempo "inacabado" e tempo "terminado". O primeiro se o reconhece cheio de previsões e antecipações para se compreender a história em curso e um aspecto prático deste tempo é a impossibilidade de se consultar livremente os arquivos que, muitas vezes, ainda estão em constituição. No segundo, é perceptível certa cristalização do evento.

Pereira (2009, p. 25) resgata os argumentos do historiador francês ao afirmar que a história não pertence apenas aos historiadores, na medida em que devem se considerar e respeitar todas as modalidades de testemunhos sobre o passado. Assim, questiona-se o fato de que, nos últimos anos, o passado chamado "mais distante" seja objeto predileto dos historiadores. (PEREIRA, 2009; GLEZER, 2007; PEREIRA \& MATA, 2012).

Despindo-se dessa roupagem tradicional, Guimarães (2006, p. 70) ressalta que a história deve ser considerada como apenas uma das inúmeras formas de elaboração significativa do tempo decorrido, como parte de algo mais amplo que o autor chamaria de "cultura histórica como parte de uma cultura de lembrança".

\subsubsection{Memória e/é história}

Pereira (2009, p. 26) salienta uma reflexão sobre a relação, segundo ele, conflituosa, entre a memória e a história no interior da HTP. A proposta de valorizar a competência dos historiadores no tocante à pesquisa em arquivos e à crítica de fontes não é suficiente para diferenciar a história da memória, "porque cada vez mais se percebe que há história na memória”. Nesse sentido, Vesentini (1997, p. 18) estabelece que entender a história como memória e perceber a integração que ocorre de maneira contínua entre a herança recebida e projetada até nós, e a reflexão a debruçar-se sobre esse passado a ser reconstruído.

Por outro lado, Rüsen (2001, p. 171) afirma que na memória há um “prolongamento temporal do passado até o presente" ou seja, que o passado seja presente por meio da narrativa. $\mathrm{O}$ anterior representa, pois, uma qualidade da experiência na relação temporal entre 
passado e presente, a ser devidamente levada em conta por um tipo apropriado de constituição narrativa de sentido.

Destarte, Halbawchs (1991, p. 36) afirma que a memória coletiva sempre se escreve no presente. "É a reconstrução da história passada no tempo presente que permite, através de um jogo de lembranças e esquecimentos, estabelecer uma identidade coletiva, exaltando, muitas vezes com sensibilidade e emoção, elementos comuns a seus membros". Assim, Rémond (1993, p. 12), estabelece que "a reintegração do tempo presente faz varrer da visão da história os últimos vestígios do positivismo". A HTP veio para mudar o entendimento da história, com uma visão semelhante ao soneto 331 de Camões: "Com tempo tudo anda e tudo para; Mas só aquele tempo que é passado; Com o tempo se não faz tempo presente”.

\subsection{As políticas linguísticas: definição e áreas de ação}

Como afirmamos no início do capítulo teórico, duas forças da Operação Global de Ensino de Línguas (OGEL) (ALMEIDA FILHO, 1993, 2007) são do nosso interesse nesta pesquisa: a história de ensino e aprendizagem de línguas num país e a operação de uma política de ensino de línguas. Nesta seção, sistematizaremos e discutiremos os pressupostos teóricos que fundamentam a nossa pesquisa. $\mathrm{O}$ autor parte de uma visão globalista do Ensino de Línguas: tudo começa no mundo das ideias e o que as influencia, separando o plano da abstração e o plano das concretudes (o ensino propriamente dito). Assim, o autor estabelece que as ações e frutos do ensino de línguas de um país ou área geográfica determinada estão condicionadas, a priori, pelas forças condicionantes que atuaram previamente.

Entendemos, pois, partindo da proposta teórica de Almeida Filho (ibidem), que o quadro atual de ensino de PLE dentro e fora do Brasil está condicionado, dentre outras forças, pelas políticas linguísticas e pela história do ensino de línguas. Definiremos, primeiramente, o conceito de políticas linguísticas para sistematizar, depois, teoricamente, as políticas de ensino de línguas.

Sobre Políticas Linguísticas (PL) apresentamos uma definição geral. Em comunicação pessoal, Almeida Filho define PL como uma intervenção informada, deliberada e sistemática concebida e acompanhada por especialistas da área da Linguagem (linguistas e linguistas aplicados) nas questões afeitas à convivência entre línguas e o status relativo delas no espaço nacional. Os argumentos expostos de Almeida Filho baseiam-se em Arnoux (1999, p. 13), que reconhece que:

O estudo das políticas linguísticas constitui um campo complexo em que a descrição e a avaliação de situações sociolinguísticas são estimuladas por necessidades sociais 
e, em grande medida, tende a propor linhas de intervenção". Por isso mesmo, aqueles que se interessam por política linguística devem aderir a certos princípios políticos, éticos, ideológicos que vão orientar sua pesquisa e suas propostas.

Assim, para Almeida Filho, o termo indica uma operação sistemática e explícita para propor soluções consistentes e estáveis a problemas envolvendo línguas em contato num país ou região e tentar alcançar objetivos envolvendo o uso público de recursos em iniciativas institucionais. Os traços distintivos de uma política são (1) a intervenção, (2) a explicitude, (3) os fins políticos, sociais e econômicos, (4) a escolha entre alternativas e, (5) a institucionalização. Notamos que o termo política, então, partindo nesse sentido epistêmico filosófico-aristotélico, vincula-se intimamente com poder e organização. (Vide BOHN 2000, p. 122). Estas intervenções na(s) língua(s) línguas de um contexto podem se dar na sua estrutura interna ou no uso que se dá àquela(s) língua(s) tidas como oficiais, não oficiais, de comércio, etc. (DE CASTRO, 2013).

\subsubsection{Políticas linguísticas e políticas de ensino de línguas}

Para Ricento (2006, p. 10), o escopo das Políticas Linguísticas (PL) é, per se, muito amplo, dada a complexidade e abrangência: questões relacionadas às línguas e a sua relação com a sociedade. $\mathrm{O}$ autor estabelece que PL é um campo de estudo relativamente recente, muito embora tenha sido discutido durante anos por pesquisadores e cientistas de diversas áreas, às vezes sem ter consciência de tal fato. As línguas e suas políticas, segundo afirma o autor, são mais pessoais do que abstratas, pois permeiam todos os aspectos da vida cotidiana. Tendo isso em mente, mostramos a sistematização que embasou a nossa pesquisa.

O conceito de PL é proposto por Calvet (1996, p. 11) como a "determinação das grandes decisões referentes às relações entre as línguas e a sociedade”. Para Vidotti (2012, p. 2), a noção de PL, embora ampla, traz em seu bojo a configuração de uma prática política, pois interfere nas situações linguísticas envolvendo, portanto, sujeitos e línguas. Para a autora, o conceito de PL encontra-se ligado à noção de planejamento linguístico, que concerne à implementação dessas decisões políticas. Fiorin (2013, p. 15), por outro lado, afirma que o conceito de planejamento linguístico foi desenvolvido principalmente por pesquisadores da Sociolinguística com acadêmicos como Bright, Ferguson, Gumperz, Haugens, Hymes e Labov, que teve no seu fazer, principalmente, aspectos inerentes às línguas, ou seja, com a sua forma. 
Assim, Vidotti (2013, p. 2) resenha que a gênese do uso do termo "planejamento linguístico" é vinculado a Einar Haugen, que em 1959 desenvolveu um estudo sobre a padronização de línguas na Noruega. Para Haugen, planejamento linguístico consiste em normatizar a ortografia, a gramática e o dicionário, visando orientar uma comunidade cujos falantes não possuem uma língua homogênea (VIDOTTI 2013, p. 2). No entanto, a autora afirma que o campo da PL tornou-se bem mais abrangente que o modelo de Haugen, "passando a tratar questões relacionadas à função da língua e seu valor na sociedade". (VIDOTTI, op. cit.).

Compartilhamos a análise proposta por Vidotti (2012) sobre a proposta teórica de Calvet (1996) de que uma PL é inseparável de sua aplicação, uma vez que uma ação (lei) por si só não se executa, mas necessita do poder para ser colocada em prática e o Estado tem os meios de implementar as escolhas políticas. Assim sendo, no dizer da autora, "o conceito de política/planejamento implica a elaboração de uma intervenção em uma situação linguística e os meios para executá-la" (VIDOTTI, 2012, p. 3).

Rajagopalan (2009) corrobora essa noção ao afirmar que uma PL "consiste em uma série de ações que objetivam intervir na vida linguística de um país. Ela é, por excelência, prescritiva e normativa" (grifo no original). No referencial teórico da tese de doutoramento de Vidotti (2013, p. 3-4), encontramos conceitos que nos serão de grande valor na hora de compreender o conceito de Políticas Linguísticas: (grifos nossos)

Calvet (1996, p. 69) classifica dois tipos de gestão das situações linguísticas: uma que procede das práticas sociais (gestão in vivo) e outra da intervenção sobre essas práticas (gestão in vitro). A primeira refere-se à forma como as pessoas resolvem problemas de comunicação no cotidiano que pode resultar nas línguas aproximativas (pidgins), ou veiculares ou promovidas (que tem suas funções ampliadas). Trata-se, portanto, de um produto de uma prática e não tem relação com uma decisão formal, como uma lei. O segundo tipo de gestão linguística (in vitro) será o analisado, pois é representado por documentos jurídicos (leis) produzidos pelo Estado. Isso implica que as decisões técnicas e políticas são impostas aos grupos sociais. Para tanto, "o Estado dispõe essencialmente da lei", de forma que "não existe planejamento linguístico sem suporte jurídico". (CALVET, 1996, p. 75).

As intervenções do Estado podem ser dar no âmbito da forma da língua (corpus), bem como na função que essa língua possa exercer (status). $O$ autor supracitado salienta que, historicamente, o poder político não apenas legislou sobre a forma da língua, como também interveio na função das línguas na sociedade. Portanto, há leis que se ocupam da forma da língua; do uso que as pessoas fazem das línguas (estabelecer língua oficial de um país, ou as línguas de trabalho em uma organização; da defesa das línguas (promoção ou proteção). (CALVET, 1996, p. 7576).

Vidotti (2012, p. 5) retoma a discussão exposta e acrescenta que a distinção entre política de corpus e status vem enriquecer a elaboração de uma abordagem que permita a análise criteriosa e um desdobramento de um tipo de ação de poder (leis) que não se ocupa da 
língua (corpus), mas do uso que as pessoas fazem das línguas e, portanto, do status destas como línguas estrangeiras (LE). Assim sendo, a autora classifica as políticas de ensino de LE como uma subcategoria da política/planejamento linguístico de status, que tem íntima relação com o conceito mais abrangente de políticas linguísticas. Apresentamos, a seguir, um quadro que resume o a taxonomia proposta pela autora:

Imagem 1: Políticas de ensino de LE no conceito de PL

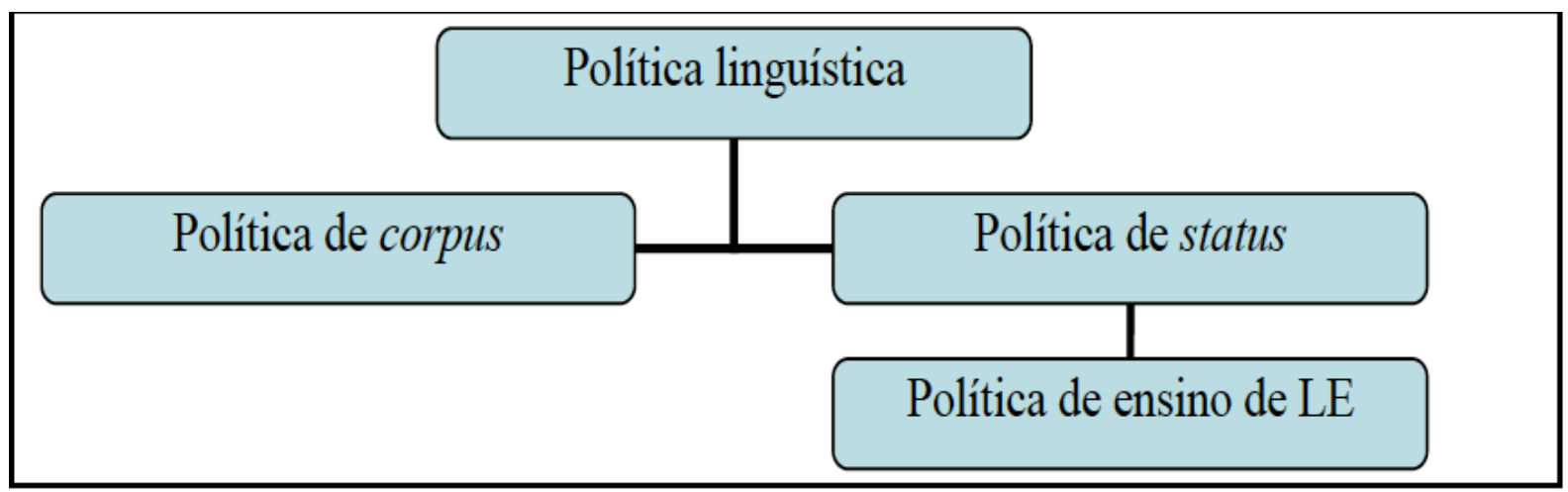

Fonte: Vidotti $(2012,2013)$

A proposta dialoga intimamente com a sistematização proposta por Hornberger (2006, p. 29), que define as políticas de ensino e difusão como uma função das políticas de status e ressalta, também, outras funções como revitalização, manutenção, comunicação internacional e transnacional.

Observamos, nesse sentido, uma proposta teórica proveitosa para situar as políticas de ensino de línguas dentro do escopo maior das políticas linguísticas. De Castro (2013, p. 27) conclui, portanto, em consonância, que é possível delimitar a política para o ensino de idiomas em relação à política linguística dizendo que a primeira é uma função específica da última, ao focar na língua como objeto de ensino. Em consonância com o proposto por De Castro (2013) e Vidotti (2012), o Projeto Glossa ${ }^{9}$, apresenta mais uma definição dois conceitos que englobam a proposta dos autores: segundo a definição do Glossa, PL é "um conjunto de decisões tomadas explicitamente como modo organizado e sistemático de ajustar o status de línguas numa dada região ou país". Embora não considere as decisões do corpus de uma língua, parece-nos uma definição adequada à nossa pesquisa.

\footnotetext{
${ }^{9}$ Projeto GLOSSA é de acervo terminológico que foi iniciado com a colaboração de alunos de graduação e pósgraduação, bem como de professores de línguas e alguns profissionais do domínio da formação de professores de línguas estrangeiras, sob a coordenação do prof. Dr. José Carlos Paes de Almeida Filho. Site disponível em: < http://glossario.sala.org.br> Acesso em 12 de out. 2015.
} 
Em consonância ao proposto por Vidotti (2012) que se abeberou da proposta teórica de Calvet (1996), retomamos que as políticas que têm relação com o ensino de línguas pertencem às políticas de status. Assim sendo, o glossário supracitado define políticas de ensino de línguas como: (grifos nossos)

\footnotetext{
Planejamento e plano contendo os direitos de aprendizagem, as justificativas educacionais, culturais e psicológicas, linguísticas e práticas do ensino e da oferta de idiomas nos currículos escolares, universitários e formativos de professores de línguas, além da definição de critérios, de quais e quantas línguas ensinar no sistema escolar, de quando e como ensiná-las ao longo da sucessão de níveis, além do modo de avaliação do desempenho adquirido.
}

Conforme a definição mais abrangente, vemos que há componentes que devem ser considerados ao avaliarmos as políticas linguísticas do status de ensino das línguas estrangeiras (no Brasil e fora dele). Assim, vemos que aspectos como direitos, justificativas, as práticas do ensino e a formação de professores devem ser algumas prioridades estabelecidas dentro de uma política instalada. Nesta dissertação, pois, focaremos nas grandes decisões institucionalizadas do governo brasileiro de promoção linguístico-cultural e ver como são refletidas em três países da América Central.

A respeito dessas grandes decisões implementadas pelo governo brasileiro no que tange ao ensino de PLE dentro e fora do Brasil, Diniz (2012, p. 19) afirma:

\begin{abstract}
Destacamos algumas iniciativas implementadas pelo Ministério da Educação brasileiro - dentre elas, o desenvolvimento e a consolidação do Celpe-Bras - e pelo Itamaraty, cuja Rede Brasileira de Ensino no Exterior (RBEx) ampliou significativamente na última década. No âmbito acadêmico, cresceram as iniciativas para a formação de professores de português como língua estrangeira a partir de meados da década de 90, através do fortalecimento de disciplinas já existentes nos cursos de Letras e da criação de novas disciplinas em programas de graduação e pós-graduação stricto sensu. Dentre essas iniciativas, destaca-se a criação do primeiro curso de Licenciatura em Português do Brasil como segunda língua, na Universidade de Brasília (UnB), em 1997. Também foi notável o aumento no número de pesquisas acadêmicas e publicações especializadas nessa área, em diferentes programas de pós-graduação no Brasil.
\end{abstract}

Para Almeida Filho (2012, p.728), esses esforços mencionados por Diniz (2012, p. 19) devem se fortalecer e afirma que há uma falta de consciência do valor estratégico de potencializar o PLE por meio de ações governamentais, como veremos a seguir: (grifos nossos)

Essa ignorância impede a introdução de disciplinas, bloqueia a contratação de professores em postos de carreira, adia a institucionalização de disciplinas no currículo que abririam portas de formação para atuação posterior de egressos de cursos de Letras como professor(a) de PLE no Brasil e em outros países. A 
valorização da Língua Portuguesa na perspectiva de uma língua estrangeira, ao contrário, carrearia vantagens em escala para os indivíduos, para as instituições e para o país em âmbitos diversos, como o das publicações especializadas, dos exames de proficiência e de materiais didáticos, por exemplo. A recomendação que já foi objeto de uma moção aprovada no II Encontro Nacional de Políticas para o Ensino de Línguas Estrangeiras (II ENPLE), por ocasião da edição da Carta de Pelotas $^{10}$, é a de que os cursos de Letras incluam imediatamente o estudo do PLE em seus currículos, de modo a alargar o horizonte de interesses acadêmicos e profissionais dos egressos.

Entretanto, vários autores afirmam que a política de ensino de línguas do Brasil necessita ser revisitada, questionada e fortalecida. Por exemplo, Picanço (2003, p. 45) caracteriza-a como "pouco clara". Sobre a política linguístico-cultural no exterior, Bagno e Carvalho (2015, p. 23), descrevem-na como "política com falta de explicitude e tímida", Diniz (2012, p 147), como "silenciosa" e "a serviço dos interesses do Estado Brasileiro"11.

$\mathrm{Na}$ resenha da literatura, observamos que as decisões sobre o ensino de PLE no exterior passam por decisões que são do interesse do Itamaraty (DE CASTRO, 2013; OLIVEIRA, 2013; BAGNO E CARVALHO, 2015). Destacamos o exposto por Diniz (2012, p. 147), (grifos nossos):

\begin{abstract}
A abertura de um Centro Cultural ou de um leitorado é, essencialmente, uma decisão política. Assim, se houver condições técnicas para tanto, polos da RBEx podem ser criados até mesmo em locais onde a procura pelo português não é grande. Esse teria sido o caso da África do Sul, cuja proximidade com a política externa brasileira levou à criação de um Centro Cultural nesse país, ainda que, em outras regiões, haja, possivelmente, um número maior de interessados em aprender português. (DINIZ, 2012, p. 165).
\end{abstract}

O autor afirma, também, que o aumento da presença da RBEx na América do Sul, na América Central e no Caribe deriva do maior investimento no chamado diálogo sul-sul por parte do Estado brasileiro, verificado nos últimos anos Conforme reconhecem documentos como o Balanço da Política Externa (2003-2010). Nesse mesmo sentido, Ricento (2006, p. 11), afirma que muita literatura a respeito das políticas linguísticas estabelece a relação íntima e indissociável entre o comportamento das línguas e as políticas sociais, afirmando que estão

\footnotetext{
${ }^{10} \mathrm{O}$ Documento se reveste de extrema importância para a história do ensino de línguas no Brasil, por dois motivos: (a) contém um diagnóstico global arguto da situação do ensino de línguas de todo o país nos mais diversos contextos e níveis, da escola pública às escolas de línguas, do ensino fundamental ao de pósgraduação, (b) mostra que os envolvidos estão comprometidos com o grande processo de ensino e aprendizagem e com as políticas públicas referentes a ele. Esses profissionais foram capazes de, à luz teórica contemporânea da Linguística Aplicada, perceber e propor medidas que beneficiassem a melhoria do ensino de línguas no Brasil. Fonte: $\quad<\quad \mathrm{http}: / /$ www.helb.org.br/index.php?option=com_content\&view=article\&id=7:a-carta-depelotas\&catid=1074:2000\&Itemid=2> Acesso em 10 de out. 2015.

${ }^{11} \mathrm{O}$ autor baseia-se num documento a que teve acesso: Documento relativo às diretrizes do Itamaraty, que explicita: "Alocar recursos de acordo com as prioridades da política externa brasileira".
} 
“ideologicamente vinculadas"12. Nesse sentido, a presença ou a ausência de uma política, afirma o autor, é também uma decisão política. (Vide, também, ORLANDI, 2007).

Encontramos, nos argumentos expostos, uma relação com o que Castro Alves (1999, p. 238) afirma: "não é obviamente de hoje que a língua e a cultura revestem e impregnam os projetos estratégicos dos países nos mais variados campos de seu relacionamento". O autor propõe o conceito de glotopolítica, definida como doutrina, prática ou disciplina que compreenderia e estudaria sistematicamente as relações de um Estado ou de uma nação com os demais, no plano regional como no plano multilateral amplo, do ponto de vista da situação da sua língua como instrumento de presença e posicionamento na comunidade internacional.

Salientamos, então, do anterior, exposto, que a língua portuguesa representa para o exdiplomata e autor Castro Alves (ibidem) um instrumento de posicionamento e reconhecimento perante as demais nações, uma manifestação soft de poder ${ }^{13}$ ou Diplomacia Cultural (DC). Assim sendo, poderíamos dizer que o ensino de PLE fora do Brasil depende dos interesses estratégicos do Itamaraty e as relações que o governo brasileiro estabelece mundo afora. Para maior compreensão dessa dinâmica entre países por meio da difusão da língua e cultura, apresentamos, a seguir, o conceito de Poder Brando ou DC.

\subsubsection{Soft Power ou DC}

Ribeiro, (1989, p. 25) oferece-nos uma definição esclarecedora: "a diplomacia cultural seria a utilização específica da relação cultural para a consecução de objetivos nacionais de natureza não somente cultural, mas também política, comercial ou econômica". A esse respeito, Da Silva (2013, p. 91) estabelece que Ribeiro (ibidem) é um dos pioneiros a estudar a Diplomacia Cultural no Brasil, ao reconhecer a DC como instrumento para alcançar objetivos políticos e econômicos. O autor assevera, também, que a DC transforma-se numa poderosa ferramenta para os interesses do Estado, a fim de garantir mais poder a ele. $\mathrm{O}$ autor se baseia nos argumentos de Ribeiro (1989, p. 25) ao afirmar que "a DC está sempre enraizada em considerações e prioridades bastante concretas".

Por outro lado, Varela (2006, apud DINIZ, 2012, p. 26) afirma que embora os fenômenos de difusão "voluntária" das línguas, na esteira de projetos de expansão política,

\footnotetext{
${ }^{12}$ No original: ideologically encumbered.

${ }^{13} \mathrm{O}$ conceito que funciona como mola propulsora dessa forma de fazer política externa, por meio da difusão da cultura e do ensino e promoção da língua se chama Poder Brando (Soft Power, em inglês). Segundo Nye (2008, apud DE CASTRO, 2013, p. 50), esse poder é a habilidade de conquistar o que se quer dos outros por meio da atratividade e não da coerção ou do pagamento. (Vide, também, FARACO, 2012).
} 
econômica e religiosa, sejam bastante antigos, não havia, até as primeiras décadas do século XX, aparelhos institucionais explicitamente encarregados de sua "gestão". Ainda hoje, são relativamente poucos os países que contam com tais aparelhos e, nesses casos, esses visam à difusão da "única língua considerada portadora da identidade nacional". (Vide, também, DE CASTRO, 2013, p. 30). Nesse sentido, Moutinho \& Almeida Filho (2014, p. 12) estabelecem que o conceito de DC é ressignificado (pois é originário da área de Relações Internacionais). Os autores entendem que:

\footnotetext{
o ensino de línguas é uma prática privilegiada de diplomacia pública na apresentação de uma cultura a outra(s) com benefícios profundos para a língua que se oferta e para a sociedade que a recebe como uma nova língua de comunicação e expressão compreensivas na consolidação do ideal da amizade e da harmonia.
}

Neste capítulo, apresentamos as perspectivas teóricas que deram suporte a nossa pesquisa. Em um primeiro momento, apresentamos uma introdução ao modelo da Operação Global de Ensino de Línguas (OGEL). Destacamos, desse modelo teórico da Linguística Aplicada, duas forças que condicionam todo o processo de ensino-aprendizagem de línguas: as políticas e a história. Comentamos, de forma sucinta, sobre as outras três: Teoria, Código de Ética e a Tradição. Em seguida, mostramos as discussões sobre a história do ensino de línguas e as políticas linguísticas. Mostramos, no embasamento teórico, que a história deve ter propósitos práticos para orientar as ações no presente. No caso das políticas, evidenciamos que permeiam as ações do dia a dia e que possuem relação direta com o nosso cotidiano . No caso da presente dissertação, mostramos que a promoção e difusão e ensino de línguas no Brasil pertencem ao campo das PL que se cristalizam no exercício da Diplomacia Cultural (ou soft power). Assim, vemos que toda decisão instalada, reconhecida governamentalmente parte de estratégias e decisões predeterminadas pelo Estado.

No capítulo seguinte, apresentamos o percurso teórico-metodológico que adotamos na presente pesquisa. 


\section{REFERENCIAL METODOLÓGICO}

No capítulo anterior, foram delimitados os pressupostos teóricos que embasaram a pesquisa de cunho histórico sobre o ensino de PLE em três países da América Central: El Salvador, Nicarágua e Costa Rica. Evidenciou-se, pois, que há uma necessidade preeminente no campo da Linguística Aplicada de pesquisas de natureza histórica. Os autores citados refletem que um dos objetivos de historicizar é servir a propósitos de conhecimento e entendimento dos processos sociais subjacentes a determinado contexto afim de ter um entendimento mais abrangente do nosso presente. Por outro lado, desdobrou-se o conceito de políticas, entendidas como grandes motores de decisões sociais em virtude de modificação de uma situação coletiva determinada no que diz respeito ao uso, à estrutura ou à difusão e promoção de línguas (L1, L2 ou LE, que é o caso da presente dissertação). Mostramos a relação de políticas para políticas linguísticas e quais as características da política exterior brasileira no que se refere à promoção de PLE no exterior. Neste capítulo, aprofundaremos nos pressupostos teóricos que deram suporte metodológico à nossa pesquisa.

\subsection{Da inerente necessidade humana de tomar para si o conhecimento}

Desde tempos longínquos, o homem teve a necessidade de construir o conhecimento e o entendimento daquilo que o cercava. Laville \& Dionne (1999, p.18) afirmam que, para sobreviver e facilitar a sua existência, o ser humano confrontou-se permanentemente com a necessidade de dispor do saber, inclusive de construí-lo por si só. Os autores estabelecem que ele fez isso de diversas maneiras antes de chegar ao que hoje é julgado como o mais eficaz: a pesquisa científica. Os antigos meios de conhecer, entretanto, não desapareceram e ainda coexistem com o método científico, que se poderia definir como uma busca sistemática e rigorosa de informações, com a finalidade de descobrir a lógica e coerência de um conjunto de dados para encontrar resposta fundamentada a um problema delimitado. (CHIZZOTTI 2006, p. 24).

Assim sendo, o propósito desse processo de construção do saber, que pode(ria) ser nomeado de pesquisa, pois, é descobrir/conhecer/fazer tangível novos conhecimentos em favor da vida humana. Para Chizzotti (2006, p. 19) isto pressupõe que o pesquisador tenha presente as concepções que orientam a sua ação, as práticas que elege para a investigação, os 
procedimentos e técnicas que adota em seu trabalho e os instrumentos de que dispõe para auxiliar seu esforço.

Assim sendo, o nosso objetivo-mor foi tentar um caminho que favorecesse o entendimento científico do contexto atual/histórico de ensino-aprendizagem de PLE/PL2 fora do Brasil, especificamente na Costa Rica, na Nicarágua e em El Salvador, com todas as suas implicações: históricas, culturais, sociais, etc. O teórico supracitado categoriza ainda a pesquisa atual em ciências humanas e sociais (dentre elas a Linguística Aplicada) em dois tipos: pesquisas quantitativas e qualitativas, que serão definidas a seguir.

\section{2 pesquisa quantitativa e qualitativa}

A pesquisa quantitativa baseia-se em meios quantificáveis para estabelecer o determinismo funcional, ou seja, a tentativa de reproduzir um evento, sob as mesmas circunstâncias em que ocorreu outras vezes para, a partir da constância e frequência que o evento mostrar, fazer predições do que ocorrerá. As pesquisas qualitativas, por outro lado, podem usar ou não quantificações, mas pretendem interpretar o sentido do evento a partir do significado que as pessoas atribuem ao que falam e fazem, de onde deriva a sua característica essencialmente interpretativista.

Ao compartilhar com seus participantes fatos e locais (como os Centros Culturais Brasileiros) que constituem objetos de pesquisa, de onde são extraídos significados e interpretações é, evidentemente, uma pesquisa qualitativa. Neste sentido, segundo Lüdke e André (1986, p. 5), afirmam ser fundamental reconhecer que não há separação entre o pesquisador e seu objeto de estudo.

Moura Filho (2010, p. 8) analisa que a pesquisa qualitativa é aquela que enfatiza a realidade socialmente construída, e afirma que existe uma relação íntima entre o pesquisador e o que é estudado, além das restrições circunstanciais que moldam a pesquisa. Segundo o autor, o enfoque qualitativo é fenomenológico, indutivo, descritivo, holístico, assumindo uma realidade dinâmica. $\mathrm{Na}$ pesquisa, não pretendemos buscar dados generalizáveis nem replicáveis. Nosso intuito foi compreender a realidade multifacetada, dinâmica do ensino de PLE nos países visitados e ver como o ensino de português se vê modificado/negociado naquele território além-fronteiras.

Por conseguinte, para desenvolver a investigação, a nosso ver, o método qualitativo foi o mais adequado. Os processos metodológicos adotados foram utilizados de forma a orientar uma pesquisa de cunho qualitativo porque além de não "privilegiar nenhuma prática 
metodológica em detrimento de outras" (Denzin \& Lincon, 2006), possibilitaram a utilização de vários procedimentos e instrumentos de coleta de dados, adequando-os aos objetivos do trabalho.

Assim, a pesquisa qualitativa busca interpretar o sentido do evento analisado a partir do significado que as pessoas atribuem ao que falam e também ao que fazem, segundo Chizzotti (2006) o que colaborou diretamente com a prevista abordagem contextual, para interpretação de dados.

Segundo o autor, pesquisa é a busca sistemática e rigorosa de informações, com a finalidade de descobrir a lógica e a coerência de um conjunto aparentemente disperso e desconexo de dados para encontrar respostas fundamentadas a um problema bem delimitado, contribuindo para o desenvolvimento do conhecimento numa área. (CHIZZOTTI 2006, p. 20).

A epistemologia interpretativista, segundo Schwandt (2006), justifica que a ação humana é inerentemente significativa, pois para que uma ação seja entendida, o investigador deve compreender o significado que constitui essa ação, pois esta possui conteúdo intencional e pertence a um sistema de significados, dentro de um contexto.

Para o autor, o significado que o intérprete reproduz/reconstrói é considerado significado original da ação, desde que o método empregado possibilite o afastamento de referenciais históricos, resultando numa atitude puramente teórica do observador. Em suma, o objetivo do interpretativismo é reconstruir as autocompreensões dos atores engajados nas ações para a compreensão científica e social.

Neste sentido, segundo Lüdke e André (1986), afirmam ser fundamental reconhecer, como já exposto, que não há separação entre o pesquisador e seu objeto de estudo e, por isso, esse trabalho vem carregado e comprometido com todas as peculiaridades do pesquisador,

Entende-se pesquisa qualitativa aplicada o trabalho que é realizado diretamente no campo de investigação buscando-se a interpretação de registros coletados. Compartilhamos, destarte, o mesmo ponto de vista dos teóricos Denzin \& Lincoln (2006, p.17) que conceituam a pesquisa qualitativa como aquela que:

Envolve uma abordagem naturalista, interpretativa, para o mundo, o que significa que seus pesquisadores estudam as coisas em seus cenários naturais, tentando entender ou interpretar, os fenômenos em termos dos significados que as pessoas a eles conferem. 
Para conhecer o contexto social e entrar no campo de pesquisa, consideramos que estudo de caso, (CHIZZOTTI 2006, p. 135), no contexto dos centros de ensino de PLE na América Central, permitirá, pelo contato direto e natural com o contexto e situações naturais do ambiente, a obtenção de dados que possam ser significativos/verossímeis. O estudo de caso será tratado na próxima seção.

\subsection{Estudo de caso como metodologia de pesquisa}

Segundo Chizzotti (2006, p. 135), o estudo de caso é bastante comum na pesquisa que tem a ver com atividades educacionais. O pesquisador deve reunir informações sobre um determinado evento ou fenômeno social, contemporâneo ou não, de natureza complexa, situado em seu contexto específico. Para o autor, o objetivo é reunir os dados de maior relevância sobre o objeto ou situação a ser estudado e, assim, alcançar um conhecimento mais amplo sobre esse fenômeno, "dissipando as dúvidas, esclarecendo questões pertinentes e, sobretudo, instruindo possíveis ações posteriores”. (Ibidem).

\subsubsection{Estudo de caso: análise documental}

Stake (1994, p. 236) afirma que o estudo de caso não é uma escolha metodológica, mas a escolha de um objeto a ser estudado. A pesquisa pode focar num caso individual, coletivo ou mesmo temático; porém, é essencial que constitua um sistema integrado. Outra característica do estudo de caso é que ele significa tanto o processo de aprendizagem sobre o caso quanto o produto da aprendizagem. Ainda assim, quanto mais específico, único, integrado em um sistema, maior a sua utilidade em termos epistemológicos.

Segundo o mesmo autor, os estudos de caso podem ser:

a) Intrínsecos: O caso não é estudado porque representa outros casos ou porque ilustra um traço ou um problema particular, mas porque, dada sua particularidade, é um caso de interesse em si mesmo;

b) Instrumentais: Um caso particular é examinado para trazer mais esclarecimentos sobre um tema ou refinamento de teoria. O caso tem um interesse secundário, uma função de suporte, facilita o entendimento de outra questão;

c) Coletivos: Estudo de um número de casos conjuntamente para inquirir sobre um fenômeno, uma população ou condições gerais. Eles são escolhidos porque se acredita que a sua compreensão levará a um melhor entendimento e a uma melhor teorização sobre uma coleção de casos. 
Neste contexto proposto, a presente pesquisa se aproxima mais de um estudo de caso coletivo. Por outro lado, não chegamos a generalizações apesar de termos a convicção de que os estudos de caso aqui apresentados possam contribuir para uma melhor teorização ou conhecimento da situação do ensino de PLE fora do Brasil como uma totalidade.

Quanto às opções de estilo à disposição dos pesquisadores que optam por fazer estudo de caso, Stake (1994, p. 241) cita cinco tipos:

a) quanto tempo utilizar para transformar o relatório em uma história;

b) até que ponto deve-se comparar o estudo que se faz com outros estudos de caso;

c) até que ponto deve-se formalizar as generalizações ou deixar essa tarefa para os leitores;

d) até que ponto deve-se salientar, no relatório do estudo de caso, uma descrição do pesquisador como participante da pesquisa;

e) Se manter ou não o anonimato dos participantes da pesquisa e em que proporção.

Bogdan \& Biklen (apud MOURA FILHO, 2005, p. 110) destacam quatro tipos de estudos de caso:

a) histórico-organizacional: foca no estudo de uma organização durante algum tempo investigando o seu desenvolvimento. O pesquisador se apoia em fontes como entrevistas com pessoas que foram ou estão relacionadas à instituição ou observação da escola na atualidade e documentos, incluindo vários registros escritos e fotografias antigas;

b) observacional: foca na observação do participante como a técnica de coleta de dados mais importante, que pode ser complementada com entrevistas formais e informais e com a consulta de documentos;

c) história de vida: foca na realização de longas entrevistas com um participante com o propósito de coletar uma narrativa em primeira pessoa, podendo ter como objetivo revelar toda a vida do(a) participante da pesquisa ou determinado período da vida da pessoa;

d) documental: foca na observação participante e nas entrevistas utilizando como fontes de informações suplementares fotografias, vídeos, filmes, apontamentos, cartas, diários e/ou registros de casos clínicos.

O estudo de caso aqui apresentado é do tipo análise documental. Desse modo, as fontes de informação mais importantes as entrevistas realizadas assim como a observação participante, análise de documentos, fotografias, outros registros, etc. Moura Filho (2010, p. 19) apresenta o estudo de caso interpretativista, no qual o papel do pesquisador é o de coletar o máximo possível de informações sobre a situação em análise, com o objetivo de analisar e interpretar o fenômeno e depois teorizar sobre ele. Assim, a pesquisa significa ir além da descrição pura e simples do que foi observado ou do que os participantes da pesquisa 
relataram nas entrevistas. Esse conceito de estudo de caso interpretativista corresponde com precisão ao trabalho por nós desenvolvido.

Moura Filho (2005, p. 109), ainda, menciona as três fases do desenvolvimento do estudo de caso propostos por Nisbet \& Watt:

1) fase aberta ou exploratória caracterizada pelo esboço de um plano de investigação que vai se definindo à proporção que o estudo se desenvolve;

2) fase de delimitação do estudo, a fase mais sistemática quanto à coleta de dados; e

3) fase da análise, que compreende a intepretação sistemática dos dados e a elaboração do relatório.

O autor mostra também a diferença entre pesquisa documental e bibliográfica, que detalharemos a seguir: a documental utiliza fontes primárias, documentos que ainda não passaram pela análise de outro pesquisador e que ainda podem ser utilizados de acordo com os objetivos da pesquisa. Já a bibliográfica, recorre a fontes secundárias, isto é, materiais que já passaram pelas mãos de outros especialistas e que já foram disponibilizados em livros, artigos acadêmicos ou jornais. A presente pesquisa é tanto documental quanto bibliográfica. A parte bibliográfica se aplica especialmente ao tratamento da primeira pergunta orientadora da pesquisa sobre o perfil história do ensino de PLE que o Brasil tem constituído no exterior desde a implementação do primeiro CEB em 1940, dando ênfase, especificamente, a três países: El Salvador, América Central.

\subsection{Alguns pressupostos sobre pesquisa histórica}

Batista (2014, p. 104) afirma que nos últimos anos o abandono dos estudos voltados a uma perspectiva histórica em Linguística Aplicada - Área da Linguagem a qual estuda a linguagem em práticas sociais - parece dar evidências de certo desequilíbrio nas definições sobre tempo, espaço, memória, língua e sociedade, bem como na noção da compreensão sobre ensino e aprendizagem.

No entanto, nas palavras da autora, "a colaboração frutífera, que a história propõe na Linguística Aplicada, equilibra estas noções com a superação dos conceitos, tematizando também os contextos políticos, econômicos e culturais do percurso da humanidade”. Eis a importância da pesquisa histórica no nosso caso. Tentaremos, agora, sistematizar a afirmação já colocada.

Entendemos pesquisa histórica como Rüsen (2010, p. 109) a define, ou seja, como um processo cognitivo (vide também VEYNE, 2014), no qual os dados das fontes são apreendidos e elaborados para concretizar ou modificar empiricamente perspectivas (teóricas) 
referentes ao passado humano. "A pesquisa é o processo no qual se obtém, dos dados das fontes, o conhecimento histórico controlável”.

Consideramos cabível a pergunta, nesse sentido de: por onde começar a fazer história? Mesmo o termo "fazer história" é sujeito a debates (GUMBRECHT, p. 465) O autor acha que é melhor colocar "fazer realidade histórica". Bloch (2001, p. 55) ao retomar o significado de fazer pesquisa histórica, afirma que, para a maioria das realidades históricas, a própria noção do "ponto inicial" permanece singularmente fugaz. O autor afirma que há, pelo menos, dois tipos de pesquisa a respeito: uma das "causas" ou "uma origem que basta para explicar", para o autor, aí mora o perigo da pesquisa histórica.

Assim, o historiador supracitado assevera que há uma pesquisa que deve se fazer: há de se estabelecer entre as diversas ordens de conhecimento uma exata simultaneidade. Ou seja, nunca se explica plenamente um fenômeno histórico fora do estudo do seu momento. "Isso é verdade para todas as etapas da evolução. Tanto para aquela em que vivemos como das outras", afirma o autor. No entanto, o teórico reconhece que deve haver um recorte situação-contexto em qualquer pesquisa que se faça.

Nesse sentido, Howatt (Ibidem, p. 3) e Almeida Filho (s/d) asseveram que qualquer análise histórica será inevitavelmente seletiva e parcial, pois "seria absurdo tentar abranger tudo". Portanto, a pesquisa histórica feita tentou abranger o contexto educacional, político, econômico no qual os CCBs foram inaugurados e, daí, começar o processo de síntese-análise da história do ensino de PLE nos países visitados.

Nessa mesma linha de análise, Handlin (1982, p. 97) assegura que o estudioso que luta para encaixar os fragmentos de formatos curiosos não pode deixar de conscientizar-se de que não há teoria interpretativa que lhe propicie mais do que um quadro provisório e parcial como orientação. O autor estabelece que a distância focal de nenhuma lente consegue enquadrar a totalidade do passado e que é mister que o historiador reconheça as múltiplas arestas na limitação de informações que colher:

\footnotetext{
Mesmo assim ele encontra aí um domínio de outra espécie, não de um universo inteiro, nem mesmo de uma montanha inteira, mas sim do fragmento que examina na totalidade. Dentro do âmbito limitado do fragmento, ele encontra revelada toda a amplitude da vida; e, também, aí as operações de numerosas forças cuja interseção se escancara diante de seus olhos. Ele conhecerá melhor seu próprio vale, pois tem consciência do lugar que ocupa na cordilheira; e as imagens teóricas podem chamarlhe a atenção para traços particulares dentro do seu raio de ação.
} 
Gumbrecht (1999, p. 484) discute também sobre essa questão e afirma que esse recorte do historiador: "é uma forma de enfatizar que os mundos cotidianos não possuem nem simetria nem centro e, portanto, podem ser abordados por muitos caminhos diferentes".

Achamos cabível a pergunta: se a história é um recorte feito pelo historiador, de onde vem essa decisão? Gumbrecht (1999, p. 475) vai afirmar que a escolha é feita conscientemente pelos laços que o historiador tem com esse período específico que pretende pesquisar. Assim, inferimos um dialogismo com a epistemologia qualitativa no fazer histórico após o começo do século XIX.

Além, disso, há escolhas feitas por motivos pragmáticos: “qualquer decisão sobre o lapso de tempo a ser tratado depende inicialmente da proporção entre as fontes disponíveis e a extensão projetada no texto". (GUMBRECHT, p. 476). O autor é consoante às ideias por Veyne (2014, p. 36) expressadas, quando manifestou que: "o interesse do historiador dependerá do estado da documentação, de suas preferências pessoais, de uma ideia que veio à mente".

Destarte, ambos autores concluem, como Veyne (2014, p. 37) afirmara nos anos 30, que a história é a projeção de nossos valores na condição de historiadores e é a resposta às perguntas que hajamos por bem fazer-lhe (Vide também RÜSEN, 2010). "Sim, a história é subjetiva, pois não se pode negar que a escolha de um assunto para um livro de história seja livre". (VEYNE, 2014, p. 37).

Não obstante, a história nem sempre foi concebida como uma escolha/prática da qual o historiador deliberadamente fazia parte. Para Silva $(2009$, p. 2) é consenso entre os historiadores que havia um princípio geral no período da ciência histórica anterior ao século XIX: considerar que o historiador não deveria auferir qualquer tipo de juízo em relação às fontes, que seu papel deveria ser de neutralidade, cabendo a ele apenas narrar e reproduzir o que diziam as fontes, a busca por leis gerais da História e, principalmente, o caráter científico, empirista. A história teve, portanto, uma influência do iluminismo positivista.

O período conhecido como positivista/historicista terá seu final anunciado nos anos inicias do século XX, sendo que o marco definitivo dessa ruptura seria a fundação, em 1929, da revista francesa Annales d'histoire Economique et Sociale, sob a direção de Marc Bloch e Lucien Febvre (BURKE, 1997, p. 17-37). (Vide capítulo teórico sobre o surgimento da escola dos Annales).

Silva (2009, p. 2) argumenta que a chamada Escola dos Annales, juntamente com o marxismo, representou o grande paradigma historiográfico no período compreendido entre as décadas de 1920 e 1970, caracterizando-se, em termos gerais, pela busca de uma história total, 
a crença na inexistência de fronteiras entre as Ciências Humanas, a vinculação da pesquisa histórica com a realidade presente do historiador e a necessidade de se fazer uma Históriaproblema (CARDOSO, 1997, p. 7-10).

O projeto da escola dos Annales era, claramente, um projeto imperialista a favor da História como eixo das Ciências Humanas (RIBEIRO, 2006, p. 5). Entretanto, mais que impor um novo paradigma historiográfico, a grande contribuição dos Annales para a História foi, nas palavras de Burke, "expandir o campo da história por diversas áreas"(BURKE, 1997, p. 126).

Consideramos, então, que trabalhar com HTP é uma ruptura dos paradigmas antigos de se fazer história, pois, como exposto, a HTP criou uma separação entre a forma positivista de se fazer história, vinculando o historiador com aquilo que pesquisa/indaga: fontes, fotografias, documentos, textos, etc. Isto, a meu ver, afina com os princípios que regem a minha pesquisa histórica por meio de um estudo de caso coletivo-documental. Por isso, Rüsen (2010, p. 169) vai afirmar que:

\begin{abstract}
A pesquisa histórica não é um fỉm em si mesmo, mas está determinada por critérios de constituição histórica (narrativa) de sentido, que orientam a pesquisa e que a conduzem, para além do trabalho com fontes, à prática comunicativa do presente em que está em jogo a identidade histórica como fator da socialização humana. A pesquisa não está vinculada apenas externamente a essa comunicação formadora de identidade, não é apenas instrumentalizada por ela, mas insere-se nela por inteiro, Ela se transforma de pesquisa (e não poderia ser de outra forma) em historiografia".
\end{abstract}

Além do anterior exposto, um aspecto da escrita da história que chama a atenção é que há autores que rejeitam a pura descrição cronológica de fatos (FARGE, 2011; GUMBRECHT, 1999; GAY, 1990; POMIAN, 1993). Os autores são partidários da escrita do detalhe, do questionamento às fontes, de olhar para aspectos nunca antes pesquisados/indagados.

Para autores como Vesentini (1997) e Veyne (2014) a escrita de indagações sobre o passado sempre será no presente, fora do tempo dos fatos ocorridos, o que é chamado por Louraux (1992, p. 58-70) como anacronismo controlado, ou seja, um intuito de percorrer um caminho de ida ao passado e retorno ao presente: "refletirei sobre o método que consiste em ir para o passado com questões do presente para voltar ao presente, com o lastro do que se compreendeu do passado" (LOURAUX, 1992, p. 61).

Veyne (2014, p. 81) estabelece categoricamente a função da história a partir do anterior exposto: "a história deve explicar [...] pois o menor fato histórico tem um sentido". Outrossim, Henry (apud VIDOTTI, 2012, p. 110) afirma que "não há 'fato' ou 'evento' 
histórico, que não faça sentido, que não peça interpretação, que não lhe achemos causas e consequências". Ora, se questionar e contar o que ninguém tinha visto antes, são ofícios do historiador, é cabível a pergunta: quais indagações devem ser feitas? Foucault (1969, p. 31) parece esboçar uma possível resposta: "por que esse acontecimento se deu dessa forma? Que processos históricos o constituem? Que singular existência é esta que vem à tona no que se diz e em nenhuma outra parte?”. Assim, a história para Rüsen (2010) é um processo denso processualmente heurístico, crítico e interpretativo e substancialmente hermenêutico, analítico e dialético.

\subsection{Instrumentos para coleta de registros, tipologia das entrevistas e análise de dados}

Chizzotti (2006, p. 72) assevera que a coleta de registros no estudo de caso (e nas pesquisas qualitativas em geral) utiliza uma variedade de estratégias e diversidade de técnicas, a partir de observações participantes e contextualizadas e de anotações feitas em campo, com o objetivo de fazer uma descrição interpretativa do modo de vida, da cultura e da estrutura social do grupo pesquisado.

Para o autor, o estudo de caso recorre assim à observação participante, à entrevista, à história de vida, às autobiografias, às práticas interacionistas de coleta de registros e quaisquer outros meios de coligir informações sugeridos pelo trabalho de campo gerados por observações atentas. Equipamentos como lápis e papel, gravadores, filmadoras, fotografias, laptops, computadores, bancos de dados, etc., são usados para registrar, coligir e sistematizar informações documentais.

No caso da nossa pesquisa, fizemos observação participante, fotografias e entrevistas, cujas tipologias resenhamos a seguir.

\subsubsection{Entrevistas}

Para Rosa e Arnoldi (2006, p. 29), a entrevista pode ser classificada, dentre outras taxonomias, em estruturada, semiestruturada e livre. No caso da pesquisa, optamos por fazer entrevistas do segundo tipo, pois, como as autoras asseveram, as questões serão formuladas de forma a permitir que o sujeito discorra e verbalize seus pensamentos, tendências e reflexões. As autoras fornecem uma compreensão maior: 
O questionamento é mais profundo e, também, mais subjetivo, levando a um relacionamento recíproco, muitas vezes, de confiabilidade. Frequentemente, elas [as entrevistas] dizem respeito a uma avaliação de crenças, sentimentos, valores, atitudes, razões e motivos acompanhados de fatos e comportamentos. Exigem que se componha um roteiro de tópicos selecionados. As questões seguem uma formulação flexível, e a sequência e as minúcias ficam por conta do discurso dos sujeitos e da dinâmica que acontece naturalmente.

As autoras afirmam que é exigido que se componha um roteiro de tópicos selecionados, mas que as questões devem seguir uma formação flexível, e a sequência e as minúcias ficam por conta do discurso dos sujeitos e da dinâmica que acontece naturalmente.

$\mathrm{Na}$ entrevista semiestruturada, questões gerais são levantadas e devem evocar ou suscitar uma verbalização que expresse o modo de pensar ou de agir das pessoas face aos temas focalizados. Devem visar, também, facilitar as lembranças dos informantes e que eles principiem a falar sobre o tema, para que se instalem, desse modo, noções de credibilidade. Cada um deverá compor uma sequência particular e abordar com mais ou menos detalhes um fato, da maneira que melhor lhe convier. Tornam-se entrevistas longas, que irão permitir tanto a análise quantitativa das respostas às questões que abordam pontos objetivos, quanto, e em especial, uma análise qualitativa do discurso dos informantes.

Para Rosa e Arnoldi (2006, p. 31), uma forma de classificar o tipo de entrevista é utilizar como referência o objetivo da mesma. Só assim poderá ser direcionada a seleção das questões a serem realizadas, podendo, então, ser estruturadas, semiestruturadas ou livres. Nahoum (apud Rosa e Arnoldi (2006, p.32), afirma que a entrevista é utilizada para averiguar algo, para entender ou para interferir em sentimentos e comportamentos.

Outra taxonomia seria a de Alonso (apud Rosa e Arnoldi 2006, p. 33) que se encaixou nos nossos propósitos de pesquisa. Trata-se da entrevista em profundidade. Para o autor, este tipo de entrevista é um processo comunicativo de extração de informação por parte de um entrevistador. Nessa informação, segundo Alonso, pode-se conhecer a biografia da pessoa entrevistada.

\subsubsection{Observação participante}

De acordo com Lima et. al. (1999), é a técnica de pesquisa menos estruturada dentre as de captação de informação nas ciências sociais, pois não depende de um instrumento de coleta estruturado. Martins (1996), especifica esta técnica como útil para compreender grupos e processos, que de outra forma não seria possível, pois a condução do processo cria condições privilegiadas de compreensão. Outro fator apontado pelo autor é o grau de 
aprofundamento desta técnica, capaz de clarear situações e momentos, a partir de um ponto de vista que não seria possível com outra técnica. Por outro lado, Chizzotti (2006, p. 90) afirma que a observação participante é obtida por meio do contato direto do pesquisador com o fenômeno observado, para recolher as ações dos atores em seu contexto natural, a partir de sua perspectiva e seus pontos de vista.

\subsection{Análise dos dados}

Após a coleta dos dados, segundo Lüdke e André (1986, p. 45), a tarefa de análise implica, num primeiro momento, a organização de todo o material, dividindo-o em partes, relacionando essas partes e procurando identificar nele tendências e padrões relevantes. Num segundo momento, essas tendências e padrões são reavaliados, buscando-se relações e inferências num nível de abstração mais elevado.

Segundo Seliger e Shohamy (1995), análise de dados objetiva examinar, organizar, resumir e sintetizar os dados para se chegar a resultados e conclusões do estudo. Assim, a análise de dados transforma o produto de todas as considerações envolvidas no projeto e no planejamento da pesquisa. A técnica para análise dos dados, para os autores, depedenderá da natureza do problema de pesquisa, o modelo definido para a investigação e o tipo de dados colhidos. Os autores afirmam, também, que na qualitativa dois tipos de técnicas podem se identificar na análise de dados: a) estabelecer categorias ao lidar com segmentos de textos retirados do texto em si, seguindo um procedimento indutivo; b) ordenar um sistema de categorias já preexistente no início do processo e que o pesquisador o aplica aos dados colhidos. Este sistema deriva ou de um quadro conceitual ou das perguntas de pesquisa.

No estudo que realizamos, o processo de análise do material coletado incluiu a leitura e releitura da degravação das entrevistas, com o propósito de organização dos mesmos, classificação, categorização, síntese e comparação entre todos os registros colhidos. Tendo como fonte principal as entrevistas, estas passaram pela seleção de aspectos mais relevantes e informações que possam corroborar, enriquecer, criar de forma fidedigna a história do PLE e o contexto de ensino na América Central. As entrevistas, vale salientar, foram transcritas e decidimos eliminar hesitações, pausas, para deixar uma leitura mais fluida e dar ênfase ao conteúdo dos depoimentos.

Além da análise das entrevistas, outros insumos/recursos foram perspectivas de entendimento/interpretação da realidade que encaramos: observações, caderno de anotações, fotografias, narrativas, experiências, textos acadêmicos, autobiografias, etc. Como toda 
pesquisa densa em campo, a análise histórica se abebera de ferramentas e recursos variados para colher os registros.

Para Pinsky \& De Luca (2011, p. 7), a história se utiliza de documentos, transformados em fontes pelo olhar do pesquisado. As autoras afirmam que estas fontes podem ser: escritas em si (cartas, diários); produções destinadas a públicos mais amplos (literatura, discursos, pronunciamentos); documentos oficiais (testamentos, inventários, registros paroquiais ou civis); materiais produzidos pelo Poder Judiciário e pelos órgãos de repressão; as fotografias (vistos como acervos documentais); patrimônio cultural, culinária, festas populares e tudo o que for capaz de expressar cultura.

Após a riqueza de ângulos de visão do fenômeno pesquisado, consideramos que a cristalização é uma maneira condizente com a pós-modernidade de nos aproximarmos da realidade que foi-nos conhecida. Richardson (1994, p. 522) propõe que a imagem para validar os textos pós-modernos não é um triângulo (rígido, fixo e bidimensional):

\footnotetext{
A imagem deve ser um cristal, pois combina simetria e substância com uma infinita variedade de formas, substâncias, transmutações, multidimensionalidades e ângulos de abordagem. Os cristais crescem, mudam, alteram-se, mas não são amorfos. Os cristais são prismas que refletem externalidades e refratam em si mesmos, criando diferentes cores, padrões, gamas, emanando em diferentes direções. O que virmos dependerá do ângulo no qual nos coloquemos.
}

Para a autora, a cristalização desconstrói a ideia de validação (pois não há só uma verdade, vemos como os textos se validam entre eles); a cristalização oferece um entendimento aprofundado, complexo e exaustivamente parcial de um assunto determinado. Paradoxalmente, sabemos mais e colocamos em dúvida o que sabemos.

\subsection{Aspectos éticos da pesquisa}

No meio acadêmico, mormente nas pesquisas de pós-graduação, a essencialidade da ética vem se fortalecendo conforme o tempo avança. $\mathrm{O}$ assunto parece gestar um código de ética e cresce sob a égide da pesquisa naturalista e a formação de pesquisadores que, em algum momento, adentrarão o campo da investigação científica.

Punch (1994, p. 90) afirma que é mister que haja um código de ética na formação de novos pesquisadores, ou seja, um código de ética deve ser apresentado, ou antes, discutido antes de o pesquisador adentrar o campo de pesquisa. 
$\mathrm{Na}$ atualidade, percebe-se que o fundamental na pesquisa é observar uma ética filosófica na qual se possam fundamentar os conceitos da ética na pesquisa mesmo sabendo que dificilmente haverá consenso sobre qual perspectiva ética adotar.

Contudo, tentamos alinhar esta pesquisa com o pensamento de Schüklenk (2005, p. 34), que afirma: "o fundamental é o reconhecimento da origem de determinadas conclusões éticas, ou seja, a capacidade de identificar qual o princípio lógico ou qual a razão ética que fundamenta tal decisão".

Parece, pois, que os pesquisadores, quando capazes de identificar o princípio lógico que fundamenta suas próprias decisões também está se capacitando para se mover por entre diferentes perspectivas éticas. Dessa forma, o princípio lógico que fundamenta este trabalho advém da perspectiva ética utilitarista, que é um tipo de raciocínio ético:

\footnotetext{
Que se mostra mais adequado para a solução das questões morais relacionadas à ética em pesquisa. Isso ocorre porque o princípio norteador desta abordagem é singular e com pouca margem para ambiguidades, o que proporciona a adoção de procedimentos claros em tomadas de decisão e também de justificativas para as escolhas adotadas. (Ibidem).
}

Acreditamos que adotando essa perspectiva ética maximiza-se a utilidade desta pesquisa pela probabilidade de ela poder contribuir para o melhor conhecimento do contexto de ensino de PLE mundo afora, contribuindo para conhecer que tipo de vínculos o Brasil tem com estas instituições que divulgam sua língua e cultura e como se deu o processo de ensino desde a criação dos Centros Culturais Brasileiros.

Assim, cada entrevistado leu e assinou um termo de consentimento e livre esclarecido (Vide APÊNDICE A). Perguntei, durante as entrevistas, se podia usar o nome dos participantes. Para a presente pesquisa, as entrevistas de maior duração foram com as diretoras do Centro Cultural Brasil-Nicarágua (CCBN); Centro Cultural Brasil- El Salvador, (CCBES) e da Fundação de Cultura, Difusão e Estudos Brasileiros (FCDEB) pois elas nos comentaram a história do ensino de língua portuguesa nesses países e nos indicaram mais pessoas dos centros de ensino. No caso de El Salvador, pessoalmente solicitamos entrevistas às professoras. No caso da Costa Rica e da Nicarágua, o contato prévio com a diretora facilitou que pudéssemos conversar com os professores.

Sobre o corpo docente, pessoal administrativo e demais entrevistados, estabeleceu-se com todos eles previamente o tempo da entrevista, para não causar surpresa nos participantes. Conversamos sobre eles sobre o termo de consentimento e livre esclarecido, perguntamos se desejavam manter o anonimato, expliquei que as informações obtidas serão do domínio da 
Universidade de Brasília, e que podem fazer uso delas como bem lhes aprouver. Todos concordaram em deixar seus nomes na entrevista. Outros participantes serão apresentados na análise de dados. Foram mais de 30 entrevistas, e o tempo total foi de 985,25 minutos ou 16,4 horas, esse volume de entrevistas foi possível graças a uma permanência em campo nos meses de janeiro, fevereiro e março de 2015.

Estabeleceu-se contato com as instituições por e-mail, previamente, e depois fomos a cada centro cultural. In loco, tivemos conversas introdutórias, que não foram gravadas, para conhecer a dinâmica da instituição, tivemos a oportunidade de conversar com os alunos, com o pessoal administrativo de cada centro visitado. Vale salientar que só colocamos na dissertação depoimentos gravados, optamos por não colocar dados ou fatos revelados off the record.

Neste capítulo, em suma, apresentamos os pressupostos metodológicos que deram suporte à nossa pesquisa. Optamos pela metodologia qualitativa, na modalidade Estudo de Caso, pois consideramos que foi a mais adequada para alcançar os nossos objetivos. Estabelecemos, também, os princípios epistêmicos da pesquisa histórica, sistematizamos os instrumentos de coleta de registros e apresentamos os participantes da pesquisa. No capítulo seguinte, apresentamos os resultados dos registros colhidos nos três países visitados: El Salvador, Nicarágua e Costa Rica. 
ANÁLISE DE REGISTROS

No capítulo anterior foram abordados os pressupostos e escolhas teóricometodológicas que embasaram a presente dissertação. No presente capítulo, apresentamos os dados colhidos durante a pesquisa in loco feita nos três países mencionados: El Salvador, Nicarágua e Costa Rica. Dos três países, então, veremos o contexto sincrônico e diacrônico, baseado nas ações institucionalizadas (no dizer de CALVET, 1996) que o Itamaraty reconhece como únicas e oficiais de difusão da língua e cultura do Brasil: Centros Culturais, Celpe-Bras, Programas de Estudante Convênio e Leitorados.

\subsection{A difusão da língua portuguesa brasileira no mundo: um recorte histórico}

De acordo com da Silva (2013), no Brasil, a promoção da língua portuguesa começou ${ }^{14}$ com a transformação do Serviço de Cooperação de Cooperação Intelectual instituído no Itamaraty pela portaria de 8 de junho de 1937 durante a governo Pimentel Brandão- na Divisão de Cooperação Intelectual do Departamento Diplomático e Consular por meio do decreto-lei n 791 de 14 de outubro de 1938 na gestão do ministro Oswaldo Aranha, e isso deu como resultado a fundação da primeira instituição além-fronteiras para a difusão da cultura brasileira, em 1940, o Instituto Cultural Uruguaio-Brasileiro, em Montevidéu que se mantém em funcionamento até hoje. (DA SILVA, 2013; DE CASTRO, 2013). Os autores relatam, também, que primeiramente foi aberta uma biblioteca brasileira e depois foram contratados professores de nível superior sob a supervisão de Antônio Houaiss (DA SILVA, 2013, p. 97).

O autor afirma que nos anos seguintes, a política de promoção da língua portuguesa baseava-se, apenas, nos Centros de Estudos Brasileiros (CEBs) (antigo nome dos Centros Culturais Brasileiros) até um momento importante na década de 1990, que foi marcada por duas situações bem distintas para a diplomacia cultural brasileira: enquanto o Brasil demonstrava apoio ao multilateralismo para a materialização de projetos de promoção e difusão da língua portuguesa, nessa mesma década, os governos de Fernando Collor, Itamar Franco e Fernando Henrique reduziam investimentos destinados ao Itamaraty e iniciaram a privatização de alguns Centros de Estudos Brasileiros, que foram incorporados por

${ }^{14}$ Da Silva (2013. p. 97) chama a atenção para o fato de que a diplomacia cultural é uma preocupação da chancelaria brasileira desde a criação na década de 1920 do Instituto Internacional de Cooperação Intelectual, órgão precursor da Unesco, na Sociedade das Nações. 
universidades estrangeiras ou transformados em Institutos Culturais (ICs) de direito privado, sendo, assim, abandonados à própria sorte. (LIMA; MARQUES; PINTO; PAES, 2008 apud DA SILVA, 2013, p. 100).

Assim, os CEB remanescentes deram lugar aos Centros Culturais Brasileiros (CCB), ligados ao Departamento Cultural do Ministério das Relações Exteriores. O site do Departamento Cultural do Itamaraty assevera que tanto os CCBs como os ICs têm como missão o ensino sistemático da língua portuguesa falada no Brasil, a difusão da literatura brasileira, a distribuição de material informativo sobre o Brasil, a organização de exposições de artes visuais e espetáculos teatrais, a coedição e distribuição de textos de autores nacionais, a difusão da música erudita e popular, a divulgação da cinematografia, além de palestras, seminários e outros. A diferença seria, basicamente, que os primeiros são subordinados diretamente ao chefe da missão diplomática brasileira, enquanto que os segundos são entidades sem fins lucrativos de direito privado que, embora autônomas, cumprem missão cultural em coordenação com as missões diplomáticas e consulares da jurisdição em que estão sediadas. (DINIZ, 2012; DE CASTRO, 2013).

Da Silva (2013, p. 102) estabelece houve uma mudança no governo do ex-presidente Luiz Inácio Lula da Silva, em 2003, e a política linguística externa brasileira ganhou novos rumos, diversificando-se. Uma das primeiras medidas do ministro Celso Amorim, escolhido pelo presidente Lula para chefiar o Ministério das Relações Exteriores, foi assinar o decreto $\mathrm{n}^{\circ} 4.759$ de 21 de junho de 2003, que criou a Divisão de Promoção da Língua Portuguesa (DPLP). Por outro lado, por meio das entrevistas e leituras, percebemos que já havia sinais importantes e relevantes por parte do governo de promoção da língua portuguesa no exterior, a DPLP, como extensão da antiga DPP, departamento que investira em cursos de formação nos anos 90 e, previamente, com a criação de Centros de Estudos Brasileiros. (Vide tabela 3). À maneira de exemplo, Diniz (2012, p. 220) afirma que as iniciativas no sentido de melhor orientar a atuação da RBEx datam desde antes dos anos 80 .

Assim, as principais ações do Estado brasileiro para a promoção internacional do português são competência da Divisão de Promoção da Língua Portuguesa (DPLP), que, subordinada ao Ministério das Relações Exteriores, atua em mais de quarenta países por intermédio da Rede Brasileira de Ensino no Exterior (RBEx), de cuja composição fazem parte os Centros Culturais Brasileiros (CCBs), os Núcleos de Estudos Brasileiros (NEBs), o CelpeBras, as Comunidades de Brasileiros e os leitorados no exterior, sendo os dois últimos recentemente acrescentados. 
Cabe destacar que, segundo Diniz (2012, p. 41), os Institutos Culturais Bilaterais (ICs) faziam parte da RBEx. No entanto, no site atualizado do Departamento Cultural do Itamaraty, as informações de tais instituições estão na aba de "Língua e cultura" e não aparecem na página oficial da RBEx.

O site supracitado oferece a seguinte informação:

Os Institutos Culturais Bilaterais são entidades sem fins lucrativos de direito privado e, embora autônomas, cumprem missão cultural em coordenação com as Missões diplomáticas e consulares da jurisdição em que estão sediadas. São eles: Instituto de Cultura Brasil-Colômbia (Bogotá), Fundação Centro de Estudos Brasileiros (Buenos Aires), Fundação Centro de Estudos Brasileiros (São José), Instituto Cultural Brasil Venezuela (Caracas), Instituto Brasil-Itália (Milão), Instituto Cultural UruguaioBrasileiro (Montevidéu) e o Instituto Brasileiro-Equatoriano de Cultura (Quito). ${ }^{15}$

Vale salientar que, para fins da presente dissertação, aprofundaremos nas ações feitas pelo governo brasileiro nos três países visitados. No entanto, apresentamos, para conhecimento do leitor, uma sucinta definição de cada linha de ação da DPLP na presente tabela (grifos nossos):

TABELA 2: ações institucionalizadas do governo brasileiro para a promoção linguístico-cultural do Brasil

\begin{tabular}{|c|c|}
\hline $\begin{array}{l}\text { Centros Culturais Brasileiros } \\
\text { (CCBs) }\end{array}$ & $\begin{array}{l}\text { Os Centros Culturais Brasileiros (CCBs) são extensões das } \\
\text { embaixadas a que estão vinculados. Os primeiros centros resultaram } \\
\text { de missões culturais enviadas pelo Itamaraty, nos anos 1940, a } \\
\text { embaixadas na América do Sul. Atualmente, os } 24 \text { centros em } \\
\text { atividade distribuem-se em quatro continentes: África (6), } \\
\text { América (13), Europa (3) e Oriente Médio (2). } \\
\text { As atividades dos CCBs concentram-se no ensino da língua } \\
\text { portuguesa, em sua vertente brasileira. Abrangem, também, } \\
\text { exposições, concertos, seminários, palestras, entre outras iniciativas } \\
\text { voltadas à difusão da cultura brasileira. }\end{array}$ \\
\hline $\begin{array}{lcc}\text { Núcleos } & \text { de } & \text { Estudos } \\
\text { Brasileiros (NEBs) } & \end{array}$ & $\begin{array}{l}\text { Os Centros Culturais são complementados por unidades de ensino } \\
\text { menores, chamadas Núcleos de Estudos Brasileiros (NEBs), situadas } \\
\text { em Embaixadas ou Vice-Consulados. Nos NEBs, um professor } \\
\text { encarrega-se de oferecer cursos de português gratuitos, além de, com } \\
\text { frequência, organizar atividades de difusão cultural, tais como festas } \\
\text { típicas e concertos de música brasileira. } \\
\text { Os NEBs, ademais, têm a função de avaliar a possibilidade de criação } \\
\text { futura de Centros Culturais, a depender da demanda local e da } \\
\text { disponibilidade de funcionários locais. } \\
\text { Atualmente, cinco NEBs operam em quatro países: Guiné Equatorial } \\
\text { (Malabo), Guatemala (Cidade da Guatemala), Paquistão (Islamabade) } \\
\text { e Uruguai (Artigas e Rio Branco). }\end{array}$ \\
\hline Leitorados & $\begin{array}{l}\text { Os leitores são professores universitários que atuam em instituições } \\
\text { estrangeiras de ensino superior, nas quais promovem a língua e a } \\
\text { cultura brasileiras. As vagas são oferecidas por meio de edital, }\end{array}$ \\
\hline
\end{tabular}

${ }^{15}$ Disponível em: http://dc.itamaraty.gov.br/lingua-e-literatura/institutos-culturais Acesso em 10 de nov. 2015 


\begin{tabular}{|c|c|}
\hline & $\begin{array}{l}\text { publicado anualmente pelo Ministério das Relações Exteriores e pela } \\
\text { CAPES (Coordenação de Aperfeiçoamento de Pessoal de Nível } \\
\text { Superior). Uma pré-seleção dos candidatos, feita pela CAPES, é } \\
\text { submetida às universidades estrangeiras, que escolhem o leitor, em } \\
\text { processo de seleção definitivo. } \\
\text { Atualmente, há } 40 \text { leitorados brasileiros em atividade. Na América } \\
\text { do Sul, há leitorados na Argentina, na Colômbia e no Chile. Na } \\
\text { América do Norte, atualmente, existe um leitorado no México e, em } \\
\text { breve, serão retomadas atividades nos Estados Unidos. Na Europa, há } \\
\text { leitores na Inglaterra, na França, na Croácia, entre outros países. A } \\
\text { África conta com leitores no Senegal, em São Tomé e Príncipe e, } \\
\text { brevemente, a África do Sul fará parte da rede de leitorados. Na Ásia, } \\
\text { China, Tailândia e Vietnã são contemplados pelo programa. }\end{array}$ \\
\hline Celpe-Bras & $\begin{array}{l}\text { O Celpe-Bras é o único certificado brasileiro de proficiência em } \\
\text { português como língua estrangeira reconhecido oficialmente pelo } \\
\text { governo do Brasil. Organizado pelo Instituto Nacional de Pesquisas } \\
\text { Educacionais Anísio Teixeira (INEP), é aplicado duas vezes ao ano, } \\
\text { em postos no Brasil e, com o apoio do MRE, no exterior. O Itamaraty } \\
\text { trabalha em coordenação com o INEP para o envio e o recebimento } \\
\text { das provas, por meio de mala diplomática, além de auxiliar no } \\
\text { cadastramento de novos postos aplicadores no exterior. } \\
\text { Centros Culturais e Núcleos de Estudos atendem a mais de } 14 \text { mil } \\
\text { alunos, além de organizarem a aplicação do Celpe-Bras. }\end{array}$ \\
\hline Comunidades Brasileiras & $\begin{array}{l}\text { No intuito de fortalecer os vínculos linguístico-culturais entre } \\
\text { brasileiros residentes no exterior e o Brasil, o Departamento Cultural } \\
\text { criou, em 2011, o Programa de Difusão de Língua e Cultura. } \\
\text { Deu-se ênfase a ações educativas, voltadas, notadamente, a filhos de } \\
\text { brasileiros que vivem no exterior, muitos dos quais, a depender das } \\
\text { circunstâncias que os cercam, correm o risco de perder contato com } \\
\text { sua língua materna. Em decorrência dessa realidade, foram priorizadas } \\
\text { atividades ligadas à capacitação de professores de Português como } \\
\text { Língua de Herança (POLH). Em contextos bilíngues ou multilíngues, a } \\
\text { manutenção do contato da criança com a língua portuguesa requer, por } \\
\text { parte dos professores (não raro os próprios pais), competências } \\
\text { especificas. } \\
\text { Pioneiramente, o Itamaraty realizou cursos de formação de professores } \\
\text { no ensino de Português como Língua de Herança em São Francisco } \\
\text { (junho de 2011), Washington (outubro de 2011), Miami (abril de } \\
\text { 2012) e Zurique (setembro de 2012), ministrados por especialistas em } \\
\text { Português Língua Estrangeira. }\end{array}$ \\
\hline
\end{tabular}

Quadro elaborado pelos autores com informações do site da Rede Brasil Cultural

De acordo com as informações publicadas no portal do Ministério das Relações Exteriores (MRE), o Departamento Cultural (DC) do Itamaraty:

O Departamento Cultural do Itamaraty é importante instrumento da diplomacia brasileira e desempenha uma variedade de de atribuições que contribuem para a maior aproximação do Brasil a outras nações. Basicamente, o DC tem por função auxiliar a divulgação, no exterior, da cultura brasileira, e, em particular, da língua 
portuguesa falada no Brasil. Além disso, ocupa-se do relacionamento do País com as instituições multilaterais de natureza cultural. ${ }^{16}$

O DC possui seis divisões: Divisão de Promoção da Língua Portuguesa (DPLP), Divisão de Operações de Difusão Cultural (DODC), Divisão de Acordos e Assuntos Multilaterais (DAMC), Divisão de Temas Educacionais (DCE), Coordenação de Divulgação (DIVULG) e Divisão de Promoção do Audiovisual (DAV). Para efeitos do nosso trabalho, concentrar-nos-emos, especificamente, na DPLP.

Diniz (2012, p. 42) afirma que a DPLP foi nomeada, até meados de 2003, Divisão de Programas de Difusão Cultural, que tinha como objetivo orientar, coordenar e executar a política cultural externa do Brasil sob a vertente da difusão da língua portuguesa e a cultura brasileiras.

Os laços diplomáticos de relações culturais entre o Brasil e os países visitados começaram a se oficializar, até onde resenhamos, com o Decreto $n^{\circ} 38.907$ de 19 de março de 1956, publicado no Diário Oficial de 21 de março de $1956^{17}$, no caso da Nicarágua; no Decreto $n^{\circ}$ 62.138, de 17 de janeiro de 1968, publicado no Diário Oficial de 19 de janeiro de $1968^{18}$, no caso de El Salvador e no acordo assinado em 19 de novembro de 1964 no caso da Costa Rica ${ }^{19}$.

A estrutura dos acordos é semelhante, mas só no caso da Nicarágua e da Costa Rica há um artigo que tem a ver com o ensino das línguas espanhola e portuguesa no território do país com o qual se assinaram os acordos:

Artigo 2: Cada uma das Altas Partes Contratantes favorecerá, nas suas Universidades, a criação de cursos especiais ou o aproveitamento dos já existentes para a melhor difusão da história, da geografia, do idioma, da literatura e de tôda a contribuição cultural da outra Alta Parte. Esse propósito de divulgação se estenderá, sempre que possível, às escolas secundárias e primárias. (BRASIL, 1956).

Artigo 1: Cada Parte Contratante se compromete a promover o intercâmbio cultural no seu mais amplo sentido, entre brasileiros e costarriquenses, apoiando a obra que, em seu território, realizem as instituições culturais, educativas, científicas, históricas ou técnicas, consagradas à difusão do idioma, e dos valôres culturais da outra Parte. (BRASIL, 1964).

\footnotetext{
${ }^{16}$ Disponível em: http://dc.itamaraty.gov.br/sobre-o-departamento Acesso em 10 de nov. 2015.

${ }^{17}$ Disponível em: $<$ http://dai-mre.serpro.gov.br/atos-internacionais/bilaterais/1953/b_3/at_download/arquivo > Acesso em 10 out. 2015

${ }^{18}$ Disponível em: < http://dai-mre.serpro.gov.br/atos-internacionais/bilaterais/1965/b_42/at_download/arquivo > Acesso em 10 de out. 2015.

${ }^{19}$ Disponível em: < http://dai-mre.serpro.gov.br/atos-internacionais/bilaterais/1964/b_28/at_download/arquivo > Acesso em 10 out. 2015. Não constavam no acordo da Costa Rica número de Decreto nem data de publicação no Diário Oficial. (Vide ANEXO D).
} 
Assim, os três acordos têm relação no sentido de promover o intercâmbio de produtos culturais: filmes, literatura, música e contempla relações acadêmicas de revalidação de diplomas, possibilidade de estudos entre o Brasil e os três países. Portanto, vemos que houve intenções de manter relações de diplomacia entre o Brasil e a América Central. Isso foi confirmado com os depoimentos de Fátima, Aline e Carminha, que já conheciam de casos de pessoas que iam ao Brasil estudar e que o processo era, segundo as entrevistadas, menos burocrático:

\begin{abstract}
Aline: Meu pai é nicaraguense, e lembro que houve um acordo de colaboração nos anos $60 \mathrm{em}$ que muitos nicaraguenses iam lá estudar Medicina na UFBA, aí conheceu minha mãe, morou 30 anos no Brasil. [...]

O CCBN nasceu exatamente por esse movimento e essa necessidade que houve nos anos 60. Os nicaraguenses que queriam estudar direito iam no Chile e os que queriam estudar Medicina iam estudar no Brasil. Lógico, época da ditadura militar. Aqui também era ditadura, então acho que por aí veio a história, então houve mais relação entre os países. Acho que por aí começa.

Fátima: Havia muitos salvadorenhos estudando no Brasil, pois na época era fácil ir ao Brasil, não havia Celpe-Bras e o dólar estava muito valorizado no Brasil, então qualquer estudante com 200 ou 300 dólares um estudante salvadorenho ou de outro país qualquer tinha uma vida razoável no Brasil.

Carminha: nos anos 70, 80 era um pouco mais fácil a entrada na universidade para um estudante estrangeiro, por isso tinha muitos salvadorenhos que conseguiram ir ao Brasil e se formar.
\end{abstract}

No que concerne ao ensino de português nesses países, a fundação das instituições oficiais encarregadas de difundirem o idioma e a cultura do Brasil ocorreu alguns anos depois de os acordos supracitados serem assinados, como mostra a tabela a seguir:

TABELA 3: Instituições oficiais de difusão linguístico-cultural nos países visitados

\begin{tabular}{|l|l|l|l|l|l|}
\hline País & Cidade & Centro Cultural & $\begin{array}{l}\text { Data de } \\
\text { fundação }\end{array}$ & Governo & $\begin{array}{l}\text { Data de } \\
\text { privatização }\end{array}$ \\
\hline Costa Rica & $\begin{array}{l}\text { San José } \\
\text { (Capital da } \\
\text { Costa Rica) }\end{array}$ & $\begin{array}{l}\text { Fundação de } \\
\text { Cultura, } \\
\text { Difusão e Estudos } \\
\text { Brasileiros } \\
\text { (FCDEB) }\end{array}$ & 1971 & Emílio Médici & $\begin{array}{l}1994 \text { (governo } \\
\text { Itamar Franco) }\end{array}$ \\
\hline Nicarágua & $\begin{array}{l}\text { Manágua } \\
\text { (Capital da } \\
\text { Nicarágua) }\end{array}$ & $\begin{array}{l}\text { Centro Cultural } \\
\text { Brasil-Nicarágua } \\
\text { CCBN }\end{array}$ & 1981 & João Figueiredo & $\begin{array}{l}\text { Ainda vinculada à } \\
\text { representação } \\
\text { diplomática do } \\
\text { Brasil }\end{array}$ \\
\hline El Salvador & $\begin{array}{l}\text { San Salvador } \\
\text { (Capital de El } \\
\text { Salvador) }\end{array}$ & $\begin{array}{l}\text { Centro Cultural } \\
\text { Brasil-El Salvador } \\
\text { (CCBES) }\end{array}$ & 1986 & José Sarney & $\begin{array}{l}\text { Ainda vinculada à } \\
\text { representação } \\
\text { diplomática do } \\
\text { Brasil }\end{array}$ \\
\hline
\end{tabular}

Fonte: Diniz, 2012 (adaptação nossa) 
Os CCBs têm uma maior presença no continente americano, que possui a maioria de instituições (13), o que representa um 54\% dos centros, ou seja, mais da metade dos CCBs encontram-se concentrados nas Américas. Para melhor compreensão, apresentamos um gráfico com o número de CCBs e a sua distribuição no mundo:

GRÁFICO 1: Número de Centros Culturais Brasileiros por continente

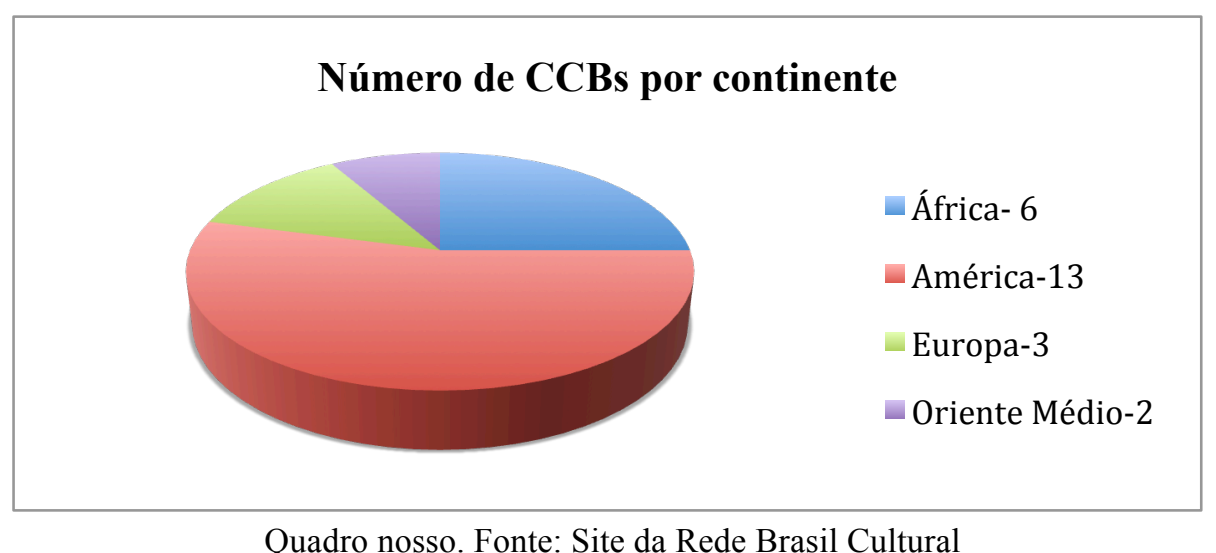

Num primeiro momento, salientamos, as instituições tinham o nome Centro de Estudos Brasileiros (CEB). Todavia, afirma Diniz, (2012, p. 72), a DPLP determinou, em setembro de 2008, a mudança na designação "Centro de Estudos Brasileiros" (CEB), conforme atesta o relatório de gestão da DPLP referente àquele ano: "os CEBs, para refletir seu crescente papel como difusores não só da língua, como também da cultura brasileira, passaram a ser denominados Centro Cultural Brasil - País Sede” (BRASIL, 2009, apud DINIZ, 2012, p. 73).

No caso da Costa Rica, o nome mudou após a sua privatização no ano 1994. Segundo nos comentaram Ana e Mércia, o desligamento foi paulatino, o financiamento foi-se reduzindo até alcançarem independência total. Ambas as entrevistadas enfatizaram o fato de a instituição não ter fins lucrativos, corroborando para o que especifica o site do Itamaraty: (grifos nossos)

Ana Lourdes: Resolveram transformar vários Centros em Fundações, como vários centros no mundo inteiro o ano não lembro muito bem. Primeiro transformaram em Fundação para que a embaixada fosse se desligando aos pouquinhos, aconteceu em vários países, não sei se todos ao mesmo tempo, mas aconteceu. Foi uma iniciativa para que a instituição ficasse independente. Para não prejudicar a instituição, a independência foi aos poucos, aí foi se desvinculando aos pouquinhos. Mandavam uma ajuda e diziam: "o CEB deve prover tanto por cento para se manter e o governo brasileiro apoia com tanto", aí essa ajuda foi diminuindo, porque antes não havia esse sentido de lucro, de fazer dinheiro, era diferente. Depois quando iniciei e voltei 
ao CEB na parte administrativa aí começamos a fazer um trabalho de "temos que ter mais alunos, temos que gerar dinheiro para poder", não era lucro de guardar dinheiro, era lucro para manter a instituição. Aí foi quando a gente começou a fazer mais propaganda, buscar mais alunos com mais afinco, porque estávamos com poucos alunos nessa época. E tivemos a sorte que nessa época o português foi, com essa questão da globalização, e tudo isso, português começou a ter seu auge. A nossa instituição não tem fins lucrativos, o dinheiro que se recebe deve-se usar para dar funcionamento e continuidade à instituição.

Mércia: Houve uma época justamente quando eu entrei, entraram as 4 pessoas que entramos na administração: a diretora, que foi por concurso; a vice-diretora e eu, entramos na mesma época, entre os anos 96-98, por aí. A diretora sempre comenta que quando recebeu a fundação, tínhamos só 70 alunos e o embaixador foi claro quando disse que se isso não melhorasse, a instituição iria fechar as portas, porque 70 alunos não era suficiente para manter uma fundação aberta. Ela começou a fazer trabalhos, a visitar empresas, oferecendo cursos em empresas e hoje em dia temos mais de mil estudantes. Mas estivemos quase a ponto de fechar porque a administração anterior... não sei... não conheci o pessoal... mas era a nossa realidade. Entrevistador: Você vivenciou a transformação CEB a Fundação?

Mércia: Sim, a diretora, nessa época, foi visitar vários institutos, porque a Costa Rica é sede de vários institutos, como o Instituto Interamericano de Cooperación Agrícola, a sede fica na Costa Rica, IBM, HP, e conseguiu levar essa informação às empresas criando grupos dentro das empresas e elas, depois, começaram a enviar alunos para a fundação e foi melhorando, foi melhorando. Começou a se divulgar mais por meio da embaixada a informação das bolsas para estudar no Brasil, então houve uma mobilização para que a população soubesse das vantagens que havia ao aprender o idioma.

A transformação do CEB para Fundação foi por própria recomendação do embaixador da época, porque um embaixador quando chega a um país demora mais ou menos 6 meses para ser credenciado como embaixador, e nós precisávamos de documentação assinada pelo embaixador e ele, no começo, não podia assinar. Então, isso gerava muita tardança para conseguir as coisas porque não tinha sido reconhecido como embaixador. Surgiu a recomendação de que a encarregada da instituição fosse a diretora como sempre foi.

Encontramos um despertar interessante na situação da Costa Rica. Percebemos que a privatização trouxe, em muitas maneiras, benefícios para a instituição, sem o abandono total do governo brasileiro. O pessoal administrativo colocou esforços para ter mais discentes, para promover o ensino do PLE na Costa Rica. Das três instituições visitadas, a Costa Rica tem a maior quantidade de alunos, a maior demanda de cursos, mais candidatos por edição de Celpe-Bras e mais infraestrutura. É semelhante ao que aconteceu na Colômbia, com o Instituto de Cultura Brasil Colômbia, muito atuante e com um número expressivo de alunos.

Na revisão da bibliografia, encontramos que Diniz (2012, p. 57) afirma que uma das diretrizes que atualmente pauta a ação cultural do Itamaraty é a substituição gradual dos ICs por CCBs e a reorganização de suas atividades. $\mathrm{O}$ autor afirma que teve acesso a documentos da DPLP para afirmar tal fato. Mesmo sendo uma proposta embrionária, ao questionar o pessoal do FCDEB sobre isso, declararam não ter conhecimento sobre tal iniciativa.

A respeito dos CCBs e do IC visitados, reconhecemos diversos pontos positivos: a infraestrutura e as salas de aula têm condições ótimas. Os três centros possuem instalações 
com perfeita infraestrutura, arborizadas, decoradas com imagens do Brasil, pinturas, esculturas, a presença das cores da bandeira do Brasil. No caso das instituições que estão diretamente vinculadas ao Itamaraty, El Salvador e a Nicarágua, todas as salas têm laptop na escrivaninha do professor, datashow instalado, sistema de som de alta qualidade, Smart TV, serviço de TV a cabo, internet wireless, cadeiras em excelente estado, quadro branco, ar condicionado. Ou seja, as condições físicas do trabalho do corpo docente são ótimas. No caso da Costa Rica, eles contam, também, com esses recursos, mas o investimento surgiu do ganho gerado na própria instituição. O que desejamos salientar nesta parte é que há intenção do Itamaraty em oferecer condições favoráveis para o ensino da língua portuguesa, assim comprovado nos CCBs visitados, conforme veremos nos seguintes depoimentos:

Fátima: $O$ Itamaraty libera verba, sim. Acho que nós temos muitos recursos, as nossas salas de aula, por exemplo, as cinco salas são ótimas: todas têm projetor, caixa de som, laptop de última geração, salas climatizadas, quadro branco, televisão, aparelho DVD, carteiras confortáveis, etc.

Aline: Quando solicitei projetores ao Itamaraty, sim foi outorgado, quando pedi recursos para pintar, sim, foi outorgado. Demora, eu sei que tem um processo administrativo, mas posso dizer que funciona.

Da mesma forma, percebemos que os CCBs visitados possuem uma ampla agenda cultural. No caso de El Salvador, vemos no $\operatorname{site}^{20}$ que houve eventos como festivais de cinema, apresentações de artistas brasileiros e salvadorenhos, concursos internos como: “quem sabe, sabe”, oficinas e palestras, festas típicas, carnaval, etc. O CCB da Nicarágua não possui website, e nas informações encontradas no Facebook ${ }^{21}$ não encontramos divulgação sobre eventos culturais. Aline comenta que alguns eventos que houve no passado são: peças de teatro, exposições de obras de arte, uma exposição de cartoons. Durante as entrevistas, comentou-nos que o CCBN não recebe verba para festivais de cinema e alguns eventos que se realizam atualmente são pagos pelos professores.

As lacunas e desafios começam a aparecer quando começamos indagar sobre recursos como a Biblioteca e acervo de livros e vídeos. O CCBES e o CCBN possuem biblioteca ${ }^{22}$, só que, para ambas as diretoras, está desatualizada e há muito tempo não recebem doações de livros recentes, dicionários, literatura brasileira moderna, como veremos nos seguintes depoimentos:

\footnotetext{
${ }^{20} \mathrm{http}: / / \mathrm{www} . c \mathrm{cbes} .0 \mathrm{rg} . \mathrm{sv}$

${ }^{21} \mathrm{https} / / / \mathrm{www}$.facebook.com/Centro-Cultural-Brasil-Nicarágua-312112483868/

${ }^{22}$ Uma discrepância nas organizações foi encontrada quando vimos o CCBN tem secretário e bibliotecária. A contratação de secretária do CCBES foi há cinco anos, aproximadamente e não há bibliotecário: estagiários cumprem essa função.
} 
Entrevistador: Vocês têm recebido livros?

Fátima: antes... nós recebíamos aqueles folhetos turísticos que nós temos aí na biblioteca que eu cuido como se fosse a minha vida, há muito tempo que não recebemos nada, revistas, nada. Aí o Brasil mandou um telegrama no ano retrasado (2013), que se nós precisássemos de livros, que nós fizéssemos uma cotação, que levantássemos o orçamento e que pedíssemos os títulos. Eu fiz a lista, isso foi para o ano retrasado. Não foi aprovada a proposta. Para o ano passado, eles mandaram dizer a mesma coisa, a proposta foi aprovada. Quando eu mandei pedir os livros, silêncio total e absoluto.

\begin{abstract}
Aline: Não, não tem muitos livros. Peço livros, peço dicionários, físicos. Pessoal diz que tem na net, e acho maravilhoso que tenha na net, mas tem gente que não tem net em casa, tem gente que não tem computador em casa, tem gente que não tem. Olha, século XXI, tá, ótimo que no Brasil todo mundo tem um computador em casa e um telefone inteligente, mas a realidade fora do Brasil é outra.
\end{abstract}

Por outro lado, o material didático usado nas três instituições é diferente. No caso de El Salvador, usava-se antigamente o livro editado pela Fundação Centro de Estudos Brasileiros de Buenos Aires (FUNCEB) chamado: "Um português bem brasileiro". Até eles receberem um telegrama no ano 2011 que não autorizava mais a compra do material e que funcionassem com o sistema de empréstimo. Fátima não concordou e pediu que os professores preparassem um material didático que é usado até hoje. São sete livros baseados no material da FUNCEB com "adaptações para a realidade salvadorenha", segundo nos comentou Isis $^{23}$. (Vide ANEXO B).

A elaboração dos materiais passou pela avaliação da diretora e na avaliação dos alunos sobre o curso, a cada trimestre, há uma pergunta específica sobre o material didático. Uma das professoras afirmou que há uma revisão e edição constante do material, que vai sendo melhorado e adaptado conforme as demandas dos discentes. No caso da Nicarágua, usa-se uma apostila que reúne vários livros de ensino de português para estrangeiros. A Costa Rica usa dois: Falar, Ler e Escrever para os cursos regulares (pois o objetivo é, segundo Susana, criar uma competência com acuidade da língua portuguesa) e Diálogo Brasil, para os cursos empresariais.

Após a apresentação das instituições, mostramos, a seguir, outro ponto que, consideramos, merece destaque na hora de apresentar o panorama do ensino de PLE alémfronteiras nos países visitados. Assim, mostramos um perfil dos docentes dos centros de ensino da língua portuguesa. Este ponto é do nosso interesse particular, pois, como demonstrado, há um interesse do Brasil em difundir a língua e a cultura, pois vemos que houve investimentos na infraestrutura, em doações passadas de livros, etc. No entanto, a nosso ver, uma dos principais pontos que observamos durante a nossa permanência em campo

${ }^{23}$ A coleção do material didático chama-se "Meu Brasil brasileiro" e foi produzido pela equipe de professores do CCBES. 
é a falta de uma política de formação dos professores de PLE. A seguir, então, pormenorizaremos.

\subsection{Perfil dos professores de Português nos países visitados da América Central}

Apresentamos, a seguir, o perfil dos professores de português nos países visitados, no qual informamos o tempo de cada professor na instituição, forma de contratação, formação superior/formação na área e capacitações recebidas ao longo da carreira de docência de PLE:

TABELA 4: Perfil dos professores de PLE em El Salvador

\begin{tabular}{|l|l|l|l|l|}
\hline $\begin{array}{c}\text { Tempo como } \\
\text { docente de } \\
\text { PLE no } \\
\text { CCBES }\end{array}$ & Contratação & $\begin{array}{c}\text { Formação } \\
\text { na área }\end{array}$ & $\begin{array}{c}\text { Formação } \\
\text { Completa }\end{array}$ & $\begin{array}{c}\text { Capacitações } \\
\text { na área de } \\
\text { PLE }\end{array}$ \\
\hline $31 \mathrm{a}$ & Convidado/concurso & Sim & Sim & 3 \\
\hline $11 \mathrm{a}$ & Concurso & Não & Sim & 3 \\
\hline $3 \mathrm{a}$ & Concurso & Não & Sim & 1 \\
\hline $20 \mathrm{a}$ & Convidado & Não & Não & 3 \\
\hline $11 \mathrm{a}$ & Concurso & Não & Não & 3 \\
\hline $2 \mathrm{a}$ & Concurso & Não & Não & 1 \\
\hline $2,5 \mathrm{a}$ & Concurso & Não & Sim & 1 \\
\hline
\end{tabular}

Na Nicarágua, estabelecemos contato com 5 dos 7 professores titulares. Somente uma tem formação em Letras Espanhol e uma tem formação em Tradução Espanhol-Inglês.

TABELA 5: Perfil dos professores de PLE na Nicarágua

\begin{tabular}{|l|l|l|l|l|}
\hline $\begin{array}{l}\text { Tempo como } \\
\text { professor (a) } \\
\text { de PLE no } \\
\text { CCBN }\end{array}$ & Contratação & $\begin{array}{l}\text { Formação } \\
\text { na área }\end{array}$ & $\begin{array}{c}\text { Formação } \\
\text { Completa }\end{array}$ & $\begin{array}{c}\text { Capacitações } \\
\text { na área de } \\
\text { PLE }\end{array}$ \\
\hline $\begin{array}{l}\text { Desde 1992, } \\
\text { com algumas } \\
\text { interrupções }\end{array}$ & Concurso & Não & $\begin{array}{l}\text { Sim (mestrado } \\
\text { em Ad. } \\
\text { Empresas) }\end{array}$ & 2 \\
\hline 7a & Concurso & Não & Não & 2 \\
\hline $9 a$ & Concurso & Não & Sim & 2 \\
\hline $\begin{array}{l}\text { Desde 1990, } \\
\text { com algumas } \\
\text { interrupções }\end{array}$ & Concurso & Sim & Sim & 2 \\
\hline 8a & Concurso & Sim & Sim & 2 \\
\hline $13 a$ & Concurso & Não & Não & 2 \\
\hline
\end{tabular}

$\mathrm{Na}$ Nicarágua, dos professores são falantes não-nativos da língua portuguesa, mas possuem vasta competência comunicativa na língua, pelo fato de terem morado no Brasil 
previamente. No caso da Costa Rica, a coordenadora pedagógica, Susana, declarou que o corpo docente da FCDEB compõe-se de 35 pessoas. Segundo afirmou: "não tem professores com formação em Letras, mas temos advogados, psicólogos, pedagogos, economistas, engenheiros, médicos". Assim, vemos que, nos três países, os professores com formação específica na área de Letras pertencem a uma minoria.

Durante as entrevistas, encontramos casos de professores que possuem formação nas áreas da saúde (Ortodontia, radiologia, etc.) Administração de Empresas e docentes que estão cursando Direito; outros não se encontram em processo de formação em carreiras, ou possuem cursos incompletos. Dos três professores que têm formação na área, somente dois estão atuando, pois uma tem cargo administrativo.

Apresentamos, a seguir, um gráfico-resumo do perfil de formação dos docentes dos países visitados. Salientamos que o total é 48 professores ativos nas três instituições dos países visitados.

GRÁFICO 2: PERFIL PROFISSIONAL DOS PROFESSORES DE PLE NOS PAÍSES VISITADOS

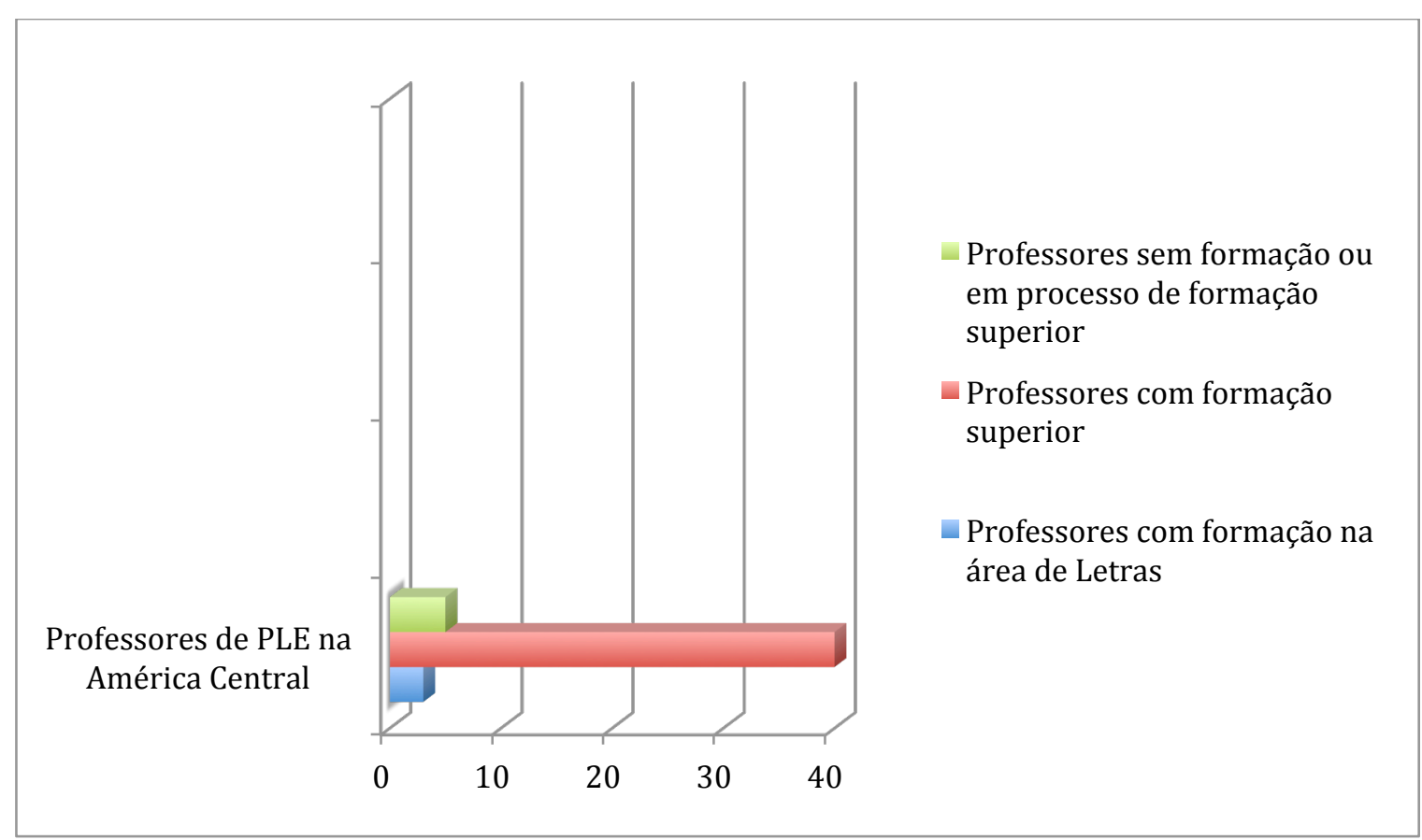

Gráfico nosso

Conforme apresentamos nas tabelas anteriores, nas quais resumimos o perfil dos professores dos países, vemos que a maioria tem uma experiência relevante em sala de aula e no caso do CCBES e CCNB, dos 14 professores ativos, 13 foram aprovados por concurso, (vide modelo de edital no ANEXO C). Isso demonstra competências profissionais desde o 
primeiro momento da contratação. Susana, na Costa Rica, afirmou que analisa previamente os potenciais candidatos a professor.

Vemos também, por outro lado, que as capacitações recebidas na área de PLE têm um número quase nulo na história das instituições. Por exemplo, vemos que há docentes em El Salvador com mais de uma ou duas décadas trabalhando no ensino de português para estrangeiros e que somente participaram de três capacitações. Conforme mostrado na tabela da Nicarágua, o panorama se repete. As capacitações e a frequência delas depende da DPLP e, segundo fomos informados, há um processo que se deve seguir para solicitá-las, como mostraremos a seguir.

As capacitações, e todos os eventos de difusão linguístico-cultural, segundo foi-nos explicado nas entrevistas, devem passar por um processo de avaliação e aceitação da DPLP. Pelo que observamos nos depoimentos, a aprovação dos eventos que têm relação com os CCBs depende das prioridades que a DPLP expuser nos comunicados oficiais enviados a cada representação diplomática fora do Brasil. Todo ano é solicitado que os diretores de todos as instituições enviem suas propostas culturais. Fátima e Aline, diretoras dos CCBES e CCBN comentaram (grifos nossos):

Fátima: Tem a DPLP que trabalha com essa questão do idioma português: Departamento de Promoção e Difusão da Língua Portuguesa. O evento que propuser, se tiver a ver com Centro Cultural, com os nossos alunos, vai para a DPLP, e eles avaliam. Mas primeiro passa pelo crivo do pessoal daqui, eles pedem para ver as propostas. Se as acharem convenientes, eles aprovam e mandam para a DPLP. No caso do Centro Cultural, eles (o Itamaraty) mandam uma lista de propostas que poderiam ser aprovadas, não é? No ano passado (2013), eles mandaram um telegrama com a lista de propostas que poderiam ser aprovadas e, nelas, eles colocaram: Capacitação para professores. Nem todo ano eles falam, eles mencionam. Então, eles querem aprimorar e... e harmonizar o ensino de Português no mundo e estão priorizando essa capacitação. No ano retrasado, 2012, eles mandaram um telegrama com as propostas e eles disseram que "poderiam levar em consideração capacitação para os professores". Eu aproveitei. Na minha lista de propostas que eles pedem que a gente enumere em ordem de prioridade, eu coloquei como prioridade: Capacitação para as professoras do Centro Cultural, então, eu já tenho os dados da pessoa que eu gostaria que viesse, formação, os honorários, os gastos com hospedagem se for estrangeiro e os outros gastos que teria aqui. Tenho que orçar tudo isso e mandar. Então, em 2013 eles aprovaram a capacitação aqui para o Centro Cultural. Foi uma semana. Daí para em 2013 para 2014 eles também priorizaram as capacitações. Eu fiz outra proposta de uma continuação para a primeira capacitação aqui, mas eu tenho a impressão de que havia outros Centros Culturais que não tinham tido capacitações e eles priorizaram e não houve capacitação aqui no ano passado. Tanto é que para este ano eu fiz um novo pedido, vamos ver o que é que eles vão achar.

Entrevistador: Você insiste em capacitação docente?

Aline: Eu insisto muito em capacitação, muito, muito.

Entrevistador: Qual é a resposta que você tem? 
Aline: (Pausa) Nenhuma. Eu acabei de fazer meu PCBB (Plano Cultural 2015). Eu propus capacitação, sempre proponho. Mas tem muitas questões que eles não propuseram, eles impuseram, como ver o Quadro Comum Europeu de Referências e ver como poderia dialogar com o Celpe-Bras. Eu peço todos os anos, mesmo não sendo diretora.

A diretora do CCBN explicou que no começo do ano 2014 receberam um Despacho Telegráfico que pedia que os diretores fizessem um texto sobre os descritores de desempenho do Celpe-Bras e ver a relação que eles poderiam ter com os descritores do Quadro Comum Europeu de Referências. O intuito era recolher informações de todas as instituições para harmonizar o currículo e o conteúdo programático dos CCBs. A capacitação dos professores, nessa questão, segundo o despacho telegráfico, poderia ser aprovada. Fátima enviou uma proposta mas foi indeferida ${ }^{24}$. Aline comentou a respeito: “então, quer dizer, você precisa passar para nós, professores, o entendimento de quais são as suas regras, os critérios para avaliar. E, honestamente, eu não entendi nada do Quadro Comum Europeu. Precisamos ter capacitação sobre isso, e ela foi negada".

Por outro lado, o caso da Costa Rica é diferente. O processo de capacitação passa pela coordenação pedagógica, no caso, de Susana. Ela explicou que sistematizou um método de formação inicial dos professores de PLE que chegam à fundação. Ela afirmou que todos os professores que atualmente estão dando aulas passaram pelo mesmo processo. Acrescentou, ainda, que posteriormente ela acompanha o desempenho dos professores por meio das avaliações que recebe dos alunos:

\begin{abstract}
Susana: Eu dou uma capacitação na qual ele sabe que o trabalho não é dele ainda. Ele começa fazendo um estágio de observação. Ele fica um mês vendo as aulas dos outros professores. Nesse momento, não falo de teoria, não falo de nada. Digo: "você vai ver. O laboratório é a sala de aula". Você vai ver o que está se fazendo aí, e com diversos professores. Aí ele faz todo isso e sento com ele e pergunto: "o que você observou?" Porque o problema não é o conteúdo, é como trabalhar. Como é transmitido. A gente não fica no "livro e página tal". A gente tem alunos que trabalharam o dia inteiro e precisa de algo dinâmico. A gente passa vídeos, áudios, músicas, a gente passa textos que possam ser polêmicos para que haja discussão, jogos, brincadeiras, tudo para que o aluno esteja, né?, por dentro, senão ele dorme. Ele tá exausto. $\mathrm{O}$ professor que observou ele tem que começar a... a gente sabe quem tem jeito e quem não tem, você logo vê. A pessoa diz assim: "poxa, eu me vejo nisso, não sei quê, não sei quê". Aí eu peço para ele dar um tema sempre algo fácil para um grupo onde eu possa avaliar, depois dele ter observado durante um mês. Eu
\end{abstract}

\footnotetext{
${ }^{24} \mathrm{Na}$ revisão bibliográfica, tivemos acesso às publicações oficiais da Em Rede Revista, que é a revista oficial da Rede Brasil Cultural. Segundo foi publicado em Rede em Revista (2015), o Quadro Comum europeu de Referência para as Línguas, o CELPE-Bras pode ser a base do marco brasileiro para maior harmonização dos CCBs e leitorados no mundo inteiro. A proposta, segundo foi informado, não recebeu até hoje seguimento nem oferta de capacitações para os docentes dos CCBs visitados.

Disponível em: http://redebrasilcultural.itamaraty.gov.br/images/Revista/REDE_EM_REVISTA_26022015.pdf Acesso em 20 jun. 2015.
} 
devo confessar que ele ensaia várias vezes a aula comigo. Ele ensaia. Por quê? Porque quem não é professor não sabe usar o recurso da lousa, por exemplo. Para que serve? Como organizar? Coisas básicas de uso desses recursos. Eu falo sobre o corpo, o movimento do corpo, o professor não deve estar sentado numa cadeira. Quantas vezes ouço: "eu adoro as aulas com esse professor porque são dinâmicas". Mas não é a aula, é ele, que não para, ele tá circulando entre os alunos e isso é muito importante. Eu passo essas ferramentas que eu vou dando e depois eu falo: "agora eu quero que você me dê essa aula a mim. Você vai ensaiar", e aí eu vou polindo. Eu passo para ele dar um tema. Se eu tenho certeza que ele é bom, a capacitação, aí sim, eu coloco alguém novo em um nível muito fácil. Eu não coloco no primeiro, porque acho que é muito difícil, coloco no nível 2, 3 aí vou fazendo plano de aula com ele. Mas o plano de aula é um relatório de tudo o que vai fazer. "Você vai chegar, vai colocar as cadeiras em círculo, entendeu? Para que tenha ali realmente um rumo e a gente faz isso todas as semanas. "Como foi a aula passada? Ok! Então, vamos fazer o planejamento da aula 2. Vai fazer assim..."

Conversamos, também, com uma das diretoras da FCDEB, Ana, e ela reiterou o que Coordenadora Pedagógica nos disse. Afirmou, por exemplo, que ela e a codiretora foram a Londrina, Paraná, no ano 2014 ao simpósio da Sociedade Internacional de Português Língua Estrangeira, SIPLE. Elas, pois, assim que retornaram à instituição, reuniram-se com o corpo docente e transmitiram os conteúdos ou fatos mais representativos do evento.

Depois de apresentar o perfil profissional dos docentes de PLE nos países por nós visitados, mostramos um breve histórico das capacitações recebidas nas instituições vinculadas diretamente ao Itamaraty, isto é, o CCBES e o CCBN. Mostraremos, de forma detalhada, quais foram e uma retroalimentação dos professores. Cabe ressaltar que tivemos acesso às avaliações feitas por eles no momento da primeira capacitação, isso nos dará insumos para avaliar os comentários dos docentes, como faremos a seguir.

\subsection{Formação recebida pelo corpo docente}

Diniz (2012, p. 220) afirma que é preciso ressaltar que iniciativas no sentido de melhor orientar a atuação da RBEx datam, pelo menos, do fim da década de 1980 e a capacitação dos professores parecia ser uma prioridade. $\mathrm{O}$ autor apresenta um parecer do Conselho Federal de Educação de 08 de junho de 1989, e cita: (grifos nossos):

Assim sendo, nos CEBs localizados na América Latina e na África - que são a prioridade do programa - as ações estarão ligadas ao desenvolvimento das áreas de cooperação educacional e intelectual, bem como a preparação, treinamento e aperfeiçoamento de recursos humanos. Já para os CEBs situados na América do Norte e na Europa, a preocupação será diversificar o campo da difusão cultural, procurando identificar, em cada Centro, a modalidade de maior receptividade para nossos produtos culturais. 
Nesse sentido, Cruz (1994, apud DINIZ, 2012, p. 221), o então chefe da Divisão de Instituições de Ensino e Programas Especiais (DIEP), expressou num informe que umas das iniciativas feitas era a "organização de seminários regionais de atualização didática para diretores, professores de CEB e leitores, com a colaboração da Universidade Estadual de Campinas". Assim, o autor supracitado menciona a realização de seminários em Montevidéu, Buenos Aires, Assunção e Barcelona, em 1993, e em Roma, em 1994, bem como a organização de mesas-redondas de diretores de Centros em São José e Santiago.

O professor Almeida Filho foi o acadêmico escolhido para dar essas capacitações fora do Brasil, devido ao currículo reconhecido e já ter um nome consolidado no círculo acadêmico na área da Linguística Aplicada ao Ensino de Línguas. Em comunicação pessoal, comentou-nos:

\footnotetext{
Lembro-me de que a primeira, ou uma das primeiras, capacitações que fiz foi na Espanha. O Ministério escolheu um lugar nesse país e lá foram colocados 27 professores. Havia professores de Eslováquia, da Rússia, da Polônia, da Alemanha, da Holanda, da França, de diversas partes da Europa. Estiveram ali comigo e os professores do Centro em que eu estava, em Barcelona. Essa foi uma das primeiras. Não era uma iniciativa aberta da DPLP (à época DIEP), mas um diretor ouviu falar de mim: um professor que estava formando professores, que tinha publicações, que estava experimentando avaliações do tipo comunicativo, que tinha orientandos que estavam fazendo pesquisas na área. Eu já era professor na pós-graduação e comecei a aparecer. Já tinha um nome, era professor de línguas, já tinha publicações, apresentações em congressos e emergia nessa época o Mercosul, nos anos 92 e 93, e daí logo veio a iniciativa de formar professores para entrar no Mercosul.
}

Essas iniciativas, conforme a entrevista concedida pelo acadêmico, foram interrompidas e retomadas só no ano de 2006. Antes disso, comentou ter sido convidado a capacitar em universidades no mundo inteiro, mas por iniciativa das instituições que o convidavam. Assim, as capacitações foram retomadas apenas nos últimos anos, particularmente, a partir da criação do Programa de Formação Intensiva Continuada para Professores de Português Língua Estrangeira (PROFIC/PLE), contratado pela DPLP. Foram realizados, no âmbito desse programa, cursos de formação na Universidade de Brasília (2006) - onde se reuniram professores de diversos CCBs - e nos Centros Culturais de Assunção (2007 e 2009), Barcelona (2007), Lima (2007 e 2010), Santo Domingo (2010) e Roma (2010). (DINIZ, 2012, p. 221).

O professor Almeida Filho corrobora a asseveração do autor supracitado: 


\begin{abstract}
Núcleo de Ensino em Português para Estrangeiros, NEPPE) e a coordenadora à época era Percília Santos. Ela captou o projeto, conversou com o pessoal da DPLP porque eles queriam um projeto para ser feito aqui em Brasília inicialmente. Percília me chamou, chamou outros colegas e tive de novo um papel forte de ajudar a criar um projeto um pouco parecido com os outros cursos que eu tinha feito, porque acho que tinha bastante experiência no grupo e se você olhar com atenção a minha presença é confirmada pelo desenvolvimento da Operação Global de Ensino de Línguas, OGEL. Isso é discernível dentro do PROFIC, só que no PROFIC a diferença foi que começamos a pensar em níveis, um, dois e mais tarde pensei no três. No começo pensamos só em um, por isso só falávamos PROFIC, depois vieram os níveis 2 e 3. Percília saiu no ano seguinte e passou a coordenação para mim e eu participava, ofertava aulas, organizava os materiais na forma de apostilas. Os professores vieram das Américas e ficaram conosco em Brasília: Guiana, Argentina, Bolívia, México, Peru e Bolívia. O PROFIC é um sistema. Quando eu assumi a coordenação, pensei: "é um sistema, é diferente dos outros. Ele não é um curso feito para um lugar. Ele é um curso durável. Nós podemos fazer esse curso e ele fica disponível. Toda vez que a DPLP precisar de um curso podemos perguntar: é a primeira vez? Ele vai no nível 1. Já fizeram o nível 1? Então, pode escolher o 2". Eu pensei em ter um sistema assim constituído.
\end{abstract}

Assim, as capacitações foram crescendo e saíram do Brasil. O professor Almeida Filho relatou que esse segundo ciclo aconteceu devido a uma verba que a DPLP havia recebido e estava fomentando muito a capacitação dos professores, de há muito reprimida como demanda. No caso de El Salvador e Nicarágua, a primeira capacitação que eles tiveram foi no México, no ano 2009 e na Nicarágua, em junho de 2010. Como mostra o documento de Prestação de Contas $\mathrm{n}^{\circ} 57$ do $\mathrm{MRE}^{25}$, em 2010, foram realizadas 5 edições do PROFIC (Programa de Formação Intensiva Continuada de Professores de Português Língua Estrangeira (PLE)), para docentes da América do Sul, América Central, América do Norte (México) e Caribe, além da Europa (Espanha, Itália e Finlândia). Com a liderança acadêmica da com a Universidade de Brasília, o documento informa que chegou a ser examinada a utilização da Internet para a realização de cursos periódicos de capacitação para professores.

No entanto, o andamento agitado das capacitações chegou a um fim abrupto. O professor Almeida Filho relata: "o dinheiro acabou rapidamente, deixando várias ofertas previstas. Depois soubemos que a verba tivera de ser compartilhada com uma orquestra brasileira que viajava pelo mundo. A DPLP teve de compartilhar o dinheiro com outras iniciativas, então murcharam as chances do PROFIC".

Após o levantamento de registros nos três países, quisemos retratar de forma aprofundada como é/foi configurado o processo de formação de professores de PLE nos países visitados.

25 Disponível em: <http://www.brasileirosnomundo.itamaraty.gov.br/associativismo-e-politicas-para-ascomunidades/ata-consolidada-de-demandas-e-prestacao-de-contas/ata-consolidada-de-demandas-e-prestacao-decontas/prestacao-de-contas-no-57.pdf> Acesso em 15 set. 2015. 
Cabe salientar neste ponto que ambas as instituições foram enfáticas ao afirmar que a participação dos professores nos PROFICs foi devido a que houve pessoas na direção que acreditavam na importância da formação do corpo docente. No caso de El Salvador, Fátima declarou ser fundamental o fato de a ex-primeira dama da República, Vanda Pignato, estar na direção, pois foi ela que fez os trâmites na embaixada para que todos os professores fossem a ambas as capacitações.

No caso da Nicarágua, Aline e a totalidade de professores entrevistados comentaram que foi graças a um diplomata, o Terceiro Secretário e ex-diretor do CCBN, Hugo Lorenzetti, formado em Letras, que capacitou previamente o pessoal. Desse modo, puderam aproveitar melhor o conteúdo transmitido nas capacitações. Dividimos, então, as tabelas por edição do PROFIC.

TABELA 6: Avaliação do PROFIC 1

\begin{tabular}{|c|c|}
\hline País & Comentários do PROFIC 1 \\
\hline \multirow[t]{3}{*}{ El Salvador } & $\begin{array}{l}\text { Os professores foram brilhantes, muito inteligentes, pessoas } \\
\text { maravilhosas, mas foi... muita teoria. E todos os participantes do PROFIC } \\
\text { I: do México, Costa Rica, Nicarágua acho que da República Dominicana } \\
\text { e nós (El Salvador), queríamos algo mais prático. Conversamos, } \\
\text { conversamos. Trocamos muitas ideias e tudo mais. Nós sabemos que o } \\
\text { método comunicativo é o ideal. Nós sabemos que a gramática deve servir } \\
\text { como um suporte, mas... como chegar a esse meio-termo? Como unir } \\
\text { gramática e texto e comunicação sem desprezar um dos dois elementos? } \\
\text { Como é que a gente pode tornar o método mais comunicativo } \\
\text { desprezando a forma? Quer dizer, em nenhum momento foi dito isso, mas } \\
\text { eles disseram que cada professor e cada Centro Cultural deveria encontrar } \\
\text { seu ponto de equilíbrio. } \\
\text { Nessa época o Celpe-Bras já tinha liberado o uso do material na sala de } \\
\text { aula, porque antes era proibido isso também. Eles deram sugestões, que a } \\
\text { gente deveria trabalhar com a televisão: usar a televisão como ajuda. Por } \\
\text { exemplo, programas, minisséries, aqueles seriados, A Grande Família, } \\
\text { pegar um dia tal assunto e ver qual é o tema de qual trata. Falou sobre a } \\
\text { aula ideal, que deveria ter sempre a parte da produção oral e da produção } \\
\text { escrita. Então, entendimento, não é? Escutar, falar, escrever. Essa é uma } \\
\text { aula ideal e eu concordo plenamente. }\end{array}$ \\
\hline & $\begin{array}{l}\text { Acho que ver um pouco a abordagem comunicativa, embora não seja tão } \\
\text { fácil de ser aplicada. O que era proposto era fazer uma coisa totalmente } \\
\text { comunicacional, só que para o nossa realidade, para os nossos alunos não } \\
\text { podemos fazer tudo assim. Temos que apresentar um pouco de gramática } \\
\text { para que os alunos se coloquem no contexto. Mas, acho que ajudou a que } \\
\text { pudéssemos reformular as nossas aulas, eu acho que tento ser um pouco } \\
\text { mais comunicativa. }\end{array}$ \\
\hline & $\begin{array}{l}\text { Eles sempre nos diziam que gramática não era legal, que nós podemos } \\
\text { ensinar o português como a gente ensina a uma criança que nasceu, aí na } \\
\text { nossa família, e ensina português pra ela e que fale como nós falamos. } \\
\text { Tudo bem. Então, eu questionava: "mas como vamos a começar isso?". E } \\
\text { até hoje estou esperando uma resposta de como começar uma aula sem } \\
\text { algo de gramática. Já sei que posso, mas porque eu inventei uma loucura e } \\
\text { funcionou, mas, mesmo assim, o livro já é uma base, eu não posso deixá- } \\
\text { lo. Eu já me acostumei com ele. }\end{array}$ \\
\hline Nicarágua & O momento foi isso que nos apresentaram abordagem, não é? Formas de \\
\hline
\end{tabular}




\begin{tabular}{|l|l|}
\hline & $\begin{array}{l}\text { abordagem que você pode ter na sala de aula. Os professores foram } \\
\text { realmente muito teóricos, mostravam aquela estrutura macro, "estamos } \\
\text { num guarda-chuva enorme, aqui esse é o teto, a estrutura da nossa casa, } \\
\text { esse é o nosso grande teto a gente precisa saber disso". Lógico, leituras } \\
\text { obrigatórias dos livros, para que a gente pudesse entender, foram feitas } \\
\text { por nós antes de sair pra lá e depois de voltar do PROFIC. Depois, o } \\
\text { assunto de material didático. }\end{array}$ \\
\hline $\begin{array}{l}\text { Foi muito teórico, mas sempre pego alguma informação que talvez não } \\
\text { tenha lido alguma coisa. Não lembro sobre que, mas fiz algumas } \\
\text { anotações. Sei que, lógico, tem muita teoria, mas procuro ler várias vezes } \\
\text { o material. }\end{array}$ \\
\hline $\begin{array}{l}\text { A avaliação é muito positiva. Mas a questão dos cursos, o que resgato foi } \\
\text { a oportunidade que tivemos de nos encontrar com os professores de } \\
\text { outros países daqui da América Central e ver como a gente estava } \\
\text { trabalhando e aí acrescentava alguma coisa. }\end{array}$ \\
\hline $\begin{array}{l}\text { Foi muito positivo porque nessa época foi o primeiro treinamento formal } \\
\text { que tive e, para mim, foi um aprendizado de como ensinar a língua } \\
\text { portuguesa e esse treinamento era dado por professores especialistas. Mas } \\
\text { eu pensei: "o que eles estão ensinando eu já sei". Para mim não era a } \\
\text { grande coisa que senti que ia ser. Sabe aquela expectativa que você tinha, } \\
\text { mas quando vi aquelas coisas eu já estava fazendo, como a parte } \\
\text { comunicativa, por exemplo. Eu vi no México que é mais importante a } \\
\text { parte da oralidade, sem esquecer a gramática, claro, porque você não pode } \\
\text { ficar só ensinando gramática. Se bem que eu sou bastante gramatical, mas } \\
\text { eu aprendi isso, que tem que trabalhar mais com a parte oral. }\end{array}$ \\
$\begin{array}{l}\text { Gostei. Os professores que chegaram mostraram o que estava } \\
\text { acontecendo no mundo, livros que tinham feito, exercícios, faziam com } \\
\text { que nós nos sentássemos e trocássemos experiências. }\end{array}$ \\
\hline
\end{tabular}

Quadro nosso

TABELA 7: Avaliação do PROFIC 2

\begin{tabular}{|c|c|}
\hline País & Comentários do PROFIC 2 \\
\hline \multirow[t]{3}{*}{ EI Salvador } & $\begin{array}{l}\text { Eles deram ideias assim, de você trabalhar sempre com coisas práticas } \\
\text { até com novelas. Eles disseram: "gente, vocês pegam, ligam a televisão. } \\
\text { Tá passando uma novela. Estão falando hoje sobre o quê? Ciúmes. Façam } \\
\text { um trabalho. Então, eu adorei essa parte, muito boa. Peguei muitas ideias } \\
\text { dos professores, assim, essas ideias práticas, e eu utilizava na minha sala } \\
\text { de aula: trabalhar com música, trabalhar com poemas, contextualizar. } \\
\text { Tudo isso eles deram. Isso no PROFIC I. Daí, um ano depois, nós fomos } \\
\text { à Nicarágua. Aí eu senti que o curso foi mais teórico que o PROFIC I. } \\
\text { Agora, eu tenho muitas coisas interessantes, apontamentos do PROFIC II } \\
\text { também que achei fundamentais: "o aluno tem que ser respeitadíssimo". } \\
\text { Não é? Você não pode, você tem que observar muito essa questão da... } \\
\text { individualidade, respeitar o aluno como um todo, jamais...jamais } \\
\text { desprezá-lo, menosprezá-lo, ser irônico, eles frisavam bem isso. Eu tenho } \\
\text { os apontamentos do PROFIC II, bem detalhado e, ainda, marcados. }\end{array}$ \\
\hline & $\begin{array}{l}\text { Acho que me ajudou no sentido de intercambiar experiências com outros } \\
\text { professores: teve professores do México, Panamá, Nicarágua, então, acho } \\
\text { que pudemos intercambiar experiências. }\end{array}$ \\
\hline & O mesmo comentário para avaliar ambas as capacitações. \\
\hline \multirow[t]{2}{*}{ Nicarágua } & $\begin{array}{l}\text { PROFIC II. Já com Hugo no PROFIC II como ele é formado da } \\
\text { UNICAMP, tinha sido aluno de grandes nomes, então, ele já sabia como } \\
\text { era o assunto. O PROFIC II aqui em Manágua, ele teve a beleza que } \\
\text { houve uma pessoa que sabia direcionar as perguntas: “tá, tudo bem. Isso } \\
\text { que você explicou tá ótimo, mas explica pro meu povo ISSO, né?". Foi } \\
\text { mais vantajoso que o primeiro. }\end{array}$ \\
\hline & O mesmo comentário para avaliar ambas as capacitações. \\
\hline
\end{tabular}




\begin{tabular}{|l|l|}
\hline & $\begin{array}{l}\text { O PROFIC II quando ele veio, tínhamos aqui que ele cuidava muito da } \\
\text { gente, o Hugo Lorenzetti, como ele estudou Letras, ele ajudou muito com } \\
\text { os gêneros e nos sentimos muito orgulhosos, porque a gente estava } \\
\text { trabalhando com gêneros textuais e para nós era o início de uma forma de } \\
\text { dar aula ajudando o aluno a escrever e falar. }\end{array}$ \\
\hline $\begin{array}{l}\text { Certas coisas que já estávamos adotando graças ao Hugo e para os demais } \\
\text { centros era uma novidade, como trabalhar com gêneros e os demais não } \\
\text { tinham entrado nessa corrente. }\end{array}$ \\
$\begin{array}{l}\text { O PROFIC daqui foi mais como: preparar uma aula, formar grupos, e aí } \\
\text { vocês fazem uma aula sobre vocabulário, o formador colocava exercios } \\
\text { como se fosse uma universidade. Uma diferença grande é que a gente } \\
\text { sentiu que estava bem preparada, pelas capacitações internas que a gente } \\
\text { teve com o professor Hugo. }\end{array}$ \\
\hline
\end{tabular}

Quadro nosso

TABELA 8: Avaliação do PROFIC 3

\begin{tabular}{|c|c|}
\hline País & Comentários do PROFIC 3 \\
\hline \multirow[t]{4}{*}{$\begin{array}{l}\text { El } \\
\text { Salvador }\end{array}$} & $\begin{array}{l}\text { Foi uma... como é que eu posso dizer... uma retomada dos PROFICs I e II. } \\
\text { Havia três professoras que não haviam participado de nenhum PROFIC e } \\
\text { de uma certa maneira elas foram beneficiadas. Sentimos que falta mais... } \\
\text { algo mais concreto. Como? Como conciliar teoria e prática? Como } \\
\text { conciliar comunicação e gramática? Como fazer isso? Como } \\
\text { contextualizar? Coisas práticas. }\end{array}$ \\
\hline & $\begin{array}{l}\text { A terceira foi muito tempo depois, mas foi continuação porque foi } \\
\text { chamada da mesma forma. O que ele fez foi dar ideias de materiais que } \\
\text { ele usava nas aulas de PLE quando morava em outro país. Para mim, não } \\
\text { foi suficiente. } \\
\text { Eu acho, claro, é impossível ensinar como dar aula, mas, pelo menos, dar } \\
\text { opções como o professor deve se posicionar perante o aluno, que } \\
\text { respostas dar diante de certas situações, como abordar, porque se o nosso } \\
\text { curso deve ser comunicativo, como ser? Como facilitar o ensino de } \\
\text { gramática? Isso, acho que isso falta e não temos isso. }\end{array}$ \\
\hline & $\begin{array}{l}\text { Deixa eu ver... eh... bom, questões gramaticais, ele foi nulo nessa parte. } \\
\text { Ele não deu aporte. O que eu gostei, foi que deu muitas ideias, deu } \\
\text { quantidade de vídeos que a gente podia usar para diversos fins, deu ideias } \\
\text { de atividades para fazer com os alunos. Não me lembro, mas eu tenho } \\
\text { anotado e muitas já fiz. Eu achei legal essa parte. }\end{array}$ \\
\hline & $\begin{array}{l}\text { Não foi o que a gente esperava. A gente, às vezes, precisa de ideias } \\
\text { também, então a gente sente que quando vem uma pessoa para capacitar, } \\
\text { você acha que essa pessoa está cheia de ideias para te ajudar um pouco. } \\
\text { Porque, às vezes, também, se você não tá buscando alguma coisa nova } \\
\text { todos os dias a tua aula pode tornar-se monótona, e a ideia não é essa, né? } \\
\text { Eu, pelo menos, sou totalmente contra um aula monótona, as minhas aulas } \\
\text { tem que ser divertidíssimas, porque é meu jeito de ser e minha forma de } \\
\text { ensinar. Então, às vezes, a gente busca nessas pessoas que vêm te dar } \\
\text { capacitação, algumas ideias também, né? E, às vezes, se enfocam naquilo } \\
\text { que você não esperava nem queria. } \\
\text { Tinha muita teoria. Foi muita teoria, muita teoria. O problema é que, às } \\
\text { vezes, os professores, eu sinto isso, quando saem para capacitar, eles já } \\
\text { levam um material pronto. E eu não sou assim. Por isso que prefiro os } \\
\text { níveis mais avançados, porque posso criar, onde posso inventar, onde não } \\
\text { tenho que me prender àquela regra de gramática, onde posso sair dela, e } \\
\text { fazer que eles FALEM comigo durante uma hora e trinta minutos. É a } \\
\text { melhor aula para mim. Então, é nessa aula que eu busco ideias, porque eu } \\
\text { tenho minhas ideias, mas não posso, o tempo todo, usar as mesmas. Como } \\
\text { eles sempre falavam que a gramática é o menos possível, que o melhor é } \\
\text { sempre falar e falar e falar. Então, eu tinha aquela sede de ideias que eles } \\
\text { iam me dar. Eu acho totalmente difícil uma aula sem gramática. Você }\end{array}$ \\
\hline
\end{tabular}




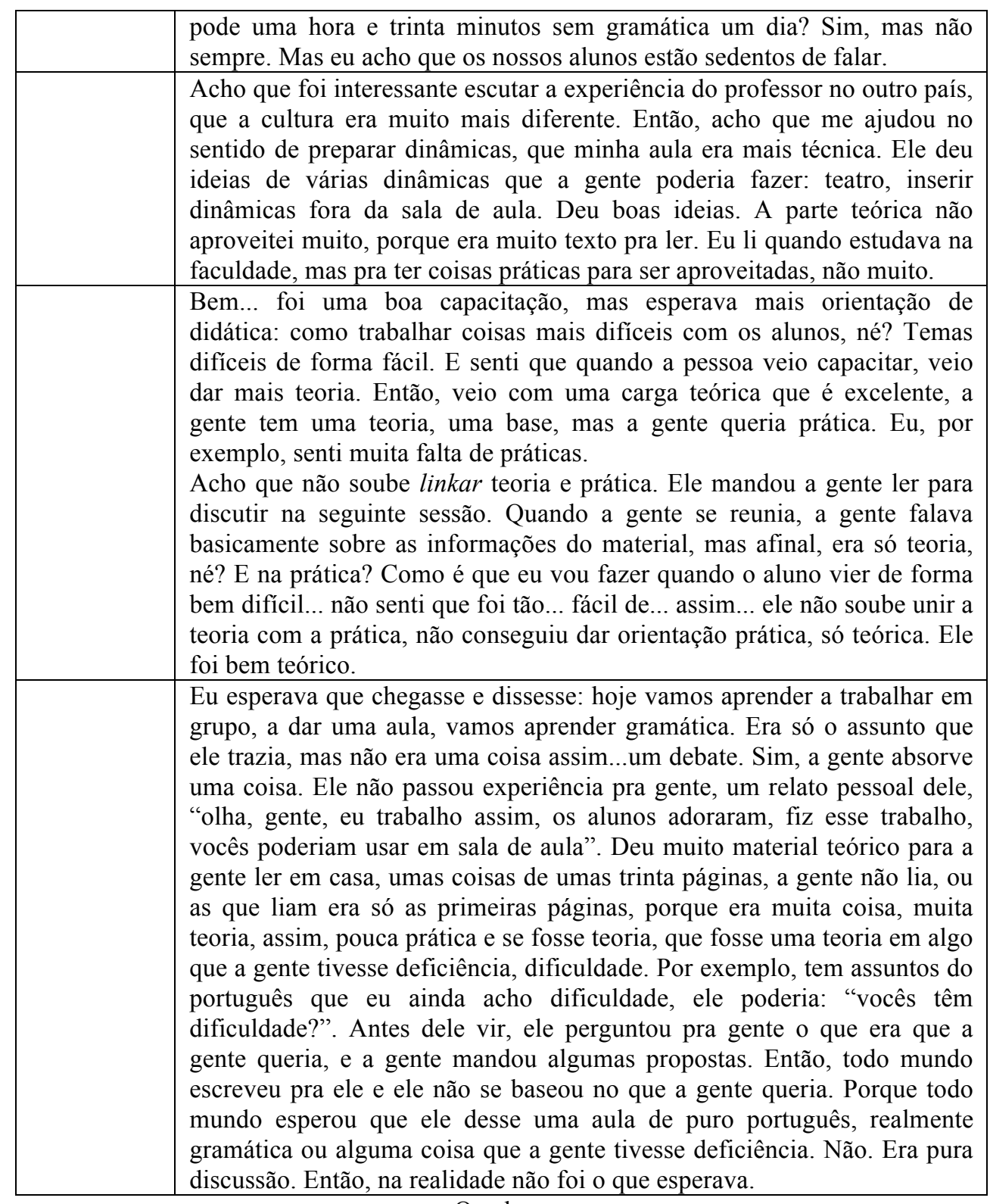

Quadro nosso

Para analisar os argumentos expostos nas entrevistas, solicitamos acesso aos questionários escritos durante o curso ofertado no México. A avaliação, elaborada pelos formadores dos cursos PROFIC, buscava abranger aspectos como: interesses dos docentes, auto-avaliação do próprio desempenho e dos facilitadores, pontos a serem melhorados, uma pergunta dos conteúdos estudados e pontos a serem considerados para melhorar a qualidade dos cursos futuros. Da totalidade de questionários respondidos, selecionamos só os dos Centros Culturais visitados e dos professores com os quais tivemos a oportunidade de 
conversar pessoalmente, totalizando 10 documentos que comentaremos e discutiremos a seguir $^{26}$.

A primeira parte compõe-se de quatro perguntas fechadas, apresentando uma escala de 1 a 4, significando o primeiro valor muito pouco ou insuficiente e o segundo indica máxima apreciação dos participantes.

Na primeira pergunta diz respeito ao interesse despertado nos docentes. A totalidade dos professores considerou máxima apreciação. A segunda, objetivava avaliar o próprio desempenho: 9 deram-se nota 3 e uma deu-se nota máxima. A terceira questão perguntava sobre a utilidade dos conteúdos para o contexto de trabalho. Todos colocaram nota máxima. A última pergunta fechada pedia uma avaliação dos facilitadores do curso, que receberam a nota mais alta por parte dos docentes da capacitação.

Neste ponto vemos uma discrepância entre o que foi-nos dito durante as entrevistas e o que foi avaliado nos questionários, pois os docentes reconheceram uma máxima utilidade dos conteúdos estudados durante a semana de capacitação, avaliaram como excelente a estrutura e organização do desenvolvimento do curso, assim como um despertar no interesse deles na hora de ter acesso a conhecimentos e leituras especializadas na área de Ensino e Aprendizagem de PLE.

A segunda parte apresenta 5 perguntas abertas. A primeira, perguntava sobre os pontos altos do curso ofertado. Encontramos as seguintes respostas: A aclaração de qual realmente é o nosso trabalho como professores de português para falantes de espanhol; diversidade de assuntos e desses um grau de aproveitamento; comecei a "pensar mais"; uma nova visão de ensino; conhecimento; a diferença de abordagens; abordagem; um ponto alto foram os palestrantes; o ensino de abordagem comunicacional; conhecer (descobrir) os tipos de abordagem.

Dessa pergunta, vemos em uma resposta que há sinais de consciência do papel que representa ser professor de português em um país hispano-falante e no resto dos professores, vemos que destacam o fato de conhecer "novas formas de ensino/novos conhecimentos". Fezse uma clara diferença ao papel transformador e revolucionário da abordagem comunicativa como um novo horizonte, um novo caminho a ser seguido para o ensino de línguas estrangeiras. Pelas respostas, vemos que há professores que não conheciam a abordagem comunicativa.

\footnotetext{
${ }^{26}$ Houve, no curso do México, professores que atuavam em outros países. Não foram tomados para a análise pois não tivemos acesso a entrevistas com eles.
} 
A segunda pergunta aberta pedia que os professores dessem sugestões para melhorar. As respostas foram: trabalhar com outros grupos de professores, mais troca de experiência; preparar-me com mais leituras e cursos; trabalho em equipe; trabalho em grupos; fazer mais atividades na aula; precisamos de mais tempo para o desenvolvimento do conteúdo ou sessões mais longas; nenhum; os materiais auxiliares (apostilas, livros); mais debates, trabalhos em grupo; mais horas-aula.

Apesar de algumas respostas serem imprecisas, reconhecemos algumas semelhanças com o que nos foi dito durante as entrevistas. Os professores ressaltaram como ponto positivo a troca de experiências e as sessões grupais como fundamentais na hora de se planejar um curso de formação docente. Da totalidade de avaliações, três docentes reforçaram o fato de ser necessário mais tempo para discutir, debater e falar sobre o conteúdo exposto. Houve um docente que achou que os materiais selecionados devem ser melhorados, mas não especificou em que sentido e uma resposta dá sinais de uma necessidade de autopreparação, de uma procura autônoma de reflexão e leituras.

A terceira pergunta pedia que os professores salientassem uma palavra/imagem/conceito marcante do curso. As respostas foram: a comunicação não tem que ser inimiga da gramática; abordagem; aquisição na área comunicativa; comunicacional; cultura; abordagem; aprendizagem; abordagem: para mim foi uma coisa revolucionária; reflexão, refletivo; abordagem comunicativa/ADQUIRIR!.

Observamos que a abordagem comunicativa aparece como protagonista, acompanhada de conceitos/construtos atrelados frequentemente a ela: como cultura e reflexão. Observamos neste ponto que houve docentes para os quais o conhecimento da alternativa ao ensino tradicional/gramatical foi um conhecimento revolucionário, frases que dão sustentação a um dos princípios da abordagem comunicativa, como que "comunicação e gramática não devem ser inimigas" ${ }^{27}$, são sinais de assimilação de conhecimentos fornecidos durante o curso, assim como a diferença de construtos aquisição/conhecimento revelam depoimentos com sinais de sofisticação teórica na hora de expressar-se. Constatamos nas entrevistas mais imprecisões conceituais ao se referir à capacitação. Afirmou-se nos questionários que o conteúdo discutido na capacitação era revolucionário, novo, e nas entrevistas foi-nos dito por alguns docentes que era algo que já dominavam.

\footnotetext{
${ }^{27}$ Almeida Filho (1993) afirma que a gramática não deve desaparecer durante o ensino que almeje ser comunicativo. Os eventuais momentos de sistematização do código linguístico, no dizer do autor, devem ocorrer dependendo das necessidades dos aprendentes, isto é, quando aquela explicitação é por eles solicitada.
} 
Um dos objetivos do curso era introduzir a reflexão no exercício docente dos professores de PLE. Como já exposto, uma professora resgatou esse conceito como fundamental durante a capacitação. Observamos que os objetivos previamente estabelecidos foram cumpridos, pois os aspectos conteudísticos foram mencionados pelos docentes e os depoimentos mostram mais interesse neles em aprofundar os conhecimentos apresentados ao longo do curso.

A quarta pergunta solicita uma verificação da teoria visitada durante a capacitação. $O$ questionário tem oito perguntas e pede-se que se responda a uma questão previamente formulada e explicitada pelos professores-facilitadores durante o curso de formação. Dentre os tópicos mencionados nas perguntas, observamos que tem uma estrutura orgânica: parte da abordagem e depois vai às concretudes e prática em sala de aula: materiais, planejamento, avaliação, papel da gramática, cultura no processo de aprender, atividades comunicativas no ensino, etc. Assim, vemos que as perguntas abrangeram os conteúdos programados previamente pela coordenação do curso. Dos docentes que preencheram as questionários, um não respondeu, teve uma resposta e os demais formularam mais perguntas.

As dúvidas escritas pediam comparações entre aplicação da gramática em uma aula comunicativa e uma aula "normal"; aspectos "mais importantes" que se devem trabalhar; até “que grau de conhecimento um professor pode chegar", como "equilibrar, realmente, o método gramatical e o comunicacional"; como "melhorar a abordagem em sala de aula"; como uma pessoa pode "ter aptidão para aprender língua"; "como aplicar a abordagem comunicacional na prática utilizando o conhecimento teórico"; o que "entendeu como abordagem comunicacional"; se o fato de "morar longe diminui as possibilidades de ser um bom professor de PLE"; e a única resposta é: "materiais fonte melhoram o aproveitamento da aula" (pedia-se que fosse descrito como ocorreria a mudança com os materiais fonte.

Após ler as avaliações orais e escritas dos professores, vemos que existe a ideia de que as abordagens (confundidas como métodos por alguns docentes) ocupam posições arquetípicas no ensino, ou que a abordagem é algo que se "adota", tanto é que nos textos fazse a distinção: aula tida como normal vs. aula comunicativa.

Abordagem não se algo que se adote. É, sim, uma filosofia de ensino, e ela se materializa em um ensinar com qualidade variável, fruto das condições internas de cada professor em sua inter-relação com condições externas em que se dá seu ensino (ALMEIDA FILHO, 2009, p. 17). A abordagem comunicativa não descarta momentos de sistematização do código linguístico, mas o foco é que a língua seja "aprendida para e na comunicação sem se restringir apenas ao 'domínio' de suas formas e do seu funcionamento enquanto sistema”. 
(ALMEIDA FILHO, 2008, p. 12). Em outras palavras, a gramática, na visão da abordagem comunicativa, privilegia o sentido, a interação, o significado sobre a rotinização e explicitação unicamente do código linguístico da língua que se deseja aprender. Outros docentes perguntaram sobre como "melhorar" a abordagem. O anterior revela, talvez, faíscas iniciais de um questionamento do próprio ensinar. Após o confronto com uma autoanálise, o professor mostrou interesse em aprimorar seu desempenho profissional. Das respostas, observamos que somente dois docentes fizeram um questionamento reflexivo da própria prática e os restantes reforçavam dúvidas e algumas imprecisões da teoria discutida durante o curso. Isto quer dizer, após a leitura de ambas as avaliações, que ainda não houve um estranhamento capaz de tirar os professores do seu presente contínuo, no dizer de Almeida Filho (2009, p. 14).

Como última pergunta, pediu-se que os professores dessem pontos que auxiliassem a melhorar a qualidade de aproveitamento do curso, ou seja, solicitou-se uma recomendação para que os conteúdos vistos pelos professores fossem num futuro melhor assimilados pelo corpo docente em serviço. As respostas solicitavam acompanhamento online posterior, mais debates; colocar as perguntas dos alunos antes da exposição dos temas; um professor escreveu que foi ótimo, mas que não teve tempo de ler todas as apostilas por falta de tempo, mas que gostaria de outro curso, para ver e avaliar se houve mudanças nos professores; outro professor escreveu que gostaria de mais cursos anuais, avaliou muito bem e pediu um certificado de participação; outra avaliação afirma que houve muitas coisas novas, mas que sentiu falta de atividades grupais; outro questionário pedia respostas concretas; soluções para os problemas apresentados e, finalmente, mais material audiovisual. Dois professores não responderam a essa pergunta.

Tivemos acesso, também, ao registro das atividades feitas pelos professores durante o curso, e observamos que dos 11 professores dos países pesquisados nesta dissertação, somente 2 executaram a análise de abordagem. Destacamos, também, das avaliações orais e das escritas, duas respostas de "não ler o material inteiro". Confirmamos nesse ponto que houve em alguns professores falta de compromisso para estudar os materiais recomendados pelos capacitadores. E, também, vemos nos depoimentos que a quantidade de professores que iniciaram ou deram sinais de um processo de auto-visitação da própria prática é baixa. Acreditamos, todavia, que as decisões inúmeras com que se defronta o professor devem se dar não à luz do dogma, da tradição, do ensino bem-sucedido, que não se explica por não se conhecerem as crenças ou da moda desejada, mas de um cada vez mais bem informado conjunto de definições e pressupostos articulados por algum modelo reconhecível, muitas 
vezes produzido por terceiros (pesquisadores) e dado a conhecer em linguagem acessível aos membros da profissão.

Assim, vemos, em ambos os casos, respostas e conclusões guiadas apenas por suas teorias pessoais informais (teoria com t minúsculo), como pensar que uma aula comunicativa é só falar, ou que a gramática não pode entrar em uma aula dita comunicativa, ou que a gramática é essencial e ocupa um lugar de privilégio durante a aula, ou pensar que se ensina uma LE como se fosse uma criança adquirindo a L1. Observamos, pois, nesses casos, teorizações informais advindas de crenças do seu próprio ensino. Para formar professores, precisa-se de mais do que ideias, do que intuições, memórias. Isso tudo, sem dúvida, é importante para dar suporte, de certa maneira, quando se ensina língua, é o que vai conduzir a aula de LE. Nem toda teoria serve aos professores de línguas, afirma Almeida Filho (2011 p. 116), servir-nos-á, sim, aquela que produz uma definição, uma explicação sobre como a estrutura de ensino/aprendizagem de línguas funciona.

Cabe conhecer, neste ponto, os princípios geradores do curso. Tivemos acesso aos documentos que deram origem às capacitações. Observamos uma estruturação orgânica e bem planejada de um curso de formação continuada para professores de PLE em serviço. Explicita-se, claramente, a importância de haver uma sequência de encontros, nos quais exista um acompanhamento do exercício docente. Como estabelece o documento (PROFIC, mimeo, 2010), o elemento mais importante no Sistema de cursos é a sua filosofia ou Abordagem Formadora: (grifos nossos)

Essa abordagem, numa palavra, é reflexiva e parte do que os professores fazem nos seus contextos e do que pensam ser uma formação (o que esperar dela), do que formar-se e do que é o trabalho formativo dos formadores. O objetivo maior é aumentar a independência de verdades prontas, da prática sem fim a que estão presos os professores e começar fazer os participantes considerar que há uma profissão em jogo informada por princípios teóricos também e que há alternativa para o ensino gramatical de longa tradição. Leitura relevante e reflexões baseadas nessa leitura e na prática são instrumentais para a formação continuada.

(2) Todos os cursos serão precedidos da construção de um planejamento escrito que será entregue aos alunos no primeiro dia de curso.

(3) Desse planejamento constarão: cabeçalho identificador do curso, nível, local e docentes responsáveis, seção de OBJETIVOS, seção de PROGRAMA (máximo de dez pontos, mínimo de 5) a ser desenvolvido pelos dois docentes, seção de AVALIAÇÃO sucinta mas acompanhada dos instrumentos que deverão ser preenchidos no último dia de aulas (as questões para serem desenvolvidas em um ou dois parágrafos podem ser ilustrativas das reais questões que serão colocadas na ficha final verdadeira em cada oferta) e seção de bibliografia específica além do que já consta do material de leitura. [...]

(5) Nos cursos em cada país, os professores estarão atentos a pormenores que nos ajudarão a planejar melhor as atividades futuras. Esses pormenores serão registrados e compartilhados como colaboração ao restante do grupo de especialistas do Sistema PROFIC. 
Observamos, também, que houve um planejamento diário, sequencial, que descrevia os conteúdos, os procedimentos e os materiais a serem usados durante a aula. Vimos, também, que no curso inicial a teoria é introduzida sequencialmente. Primeiro, buscou-se, segundo o roteiro, um entrosamento da turma, com leituras que discutem sobre o que é ensinar português, como chegaram a essa profissão, qual é o papel dos professores perante os desafios do ensino de PLE, indicações de uma atividade individual reflexiva sobre análise de abordagem e traçar atuações futuras de produção e discussão diária. Também, uma atividade grupal, com o conceito de abordagem e as quatro materialidades (único aspecto conteudístico teórico do dia) e com propostas de reflexão diária, discussão e aplicação para os institutos aos quais os docentes pertenciam.

Depois, o roteiro descreve os passos para um autoconhecimento na condição de professores de PLE, e os primeiros passos de descobrimento da própria abordagem por meio de roteiro reflexivo e um pequeno texto para ser entregue aos formadores com as primeiras reflexões do exercício profissional dos participantes baseado na experiência deles. Ao ler o roteiro inteiro, percebemos que não estava imbuído de discussões gramaticais, os aspectos teóricos eram propositados, justificados e conduzidos conforme as discussões iam acontecendo.

Nesse sentido, vemos que existem algumas discrepâncias entre o que os professores afirmaram nas entrevistas e nos questionários e os documentos que nortearam o curso. Percebemos que os professores no momento da capacitação, avaliaram com comentários excelentes o desempenho dos formadores, mas quase 10 anos depois, a tradição e as crenças advindas de memórias e pressuposições tomaram conta da teorização com t minúsculo com o a qual os docentes defendem o que fazem o por que o fazem assim.

Compartilhamos, pois, a visão de Almeida Filho (2008, p. 12), que a formação de professores é uma atividade delicada, porém possível e esta deve se materializar mediante reflexão sistemática-teoricamente informada que pode(ria) gerar mudanças na direção desejada, no dizer do autor. Cavalcanti \& Moita Lopes (1991 apud BLATYTA, 2009) defendem a necessidade de reflexão, teoricamente informada, sobre a prática de sala de aula, como meio de aperfeiçoamento do que se passa nesse ambiente. Blatyta (2009, p. 67) afirma, ainda: 
explícitas sobre abordagem. A compreensão das teorias explícitas é atravessada por teorias implícitas, fruto das experiências pessoais de cada professor. Afinal, conforme Pennycook (1989) afirma, os indivíduos são produto de histórias particulares, que perseveram no habitus ${ }^{28}$, e suas ações nunca podem ser analisadas adequadamente apenas como resultado de um cálculo consciente. O conhecimento é produzido dentro de uma particular configuração de circunstâncias sociais, culturais, econômicas, políticas e históricas. Atualizar conhecimentos, sair de rotinas estabelecidas, implica também em trazer à tona e analisar teorias implícitas, ressignificando-as em novas configurações.

Assim, concordamos com a autora e com Almeida Filho (2011, p. 30) que o professor deve intercalar observações (do próprio ensinar e de outrem), análise, leituras esclarecedoras, mais pensar, mais discussão, mais observações com registros da realidade, mais análise, mais leitura, constantemente. Por isso, no planejamento do curso sequencial, expunha-se a necessidade de haver mais cursos PROFIC, que em países como o Peru, que no ano 2015 teve a sexta capacitação de formação continuada para professores de PLE.

Embora a teoria seja reconhecida como necessária em alguns depoimentos, concluímos que não houve neles um processo reflexivo que promovesse uma mudança no exercício profissional. Pelo descrito nas entrevistas, alguns professores não fizeram as leituras, prejudicando a assimilação dos conteúdos neles contidos, pois, conforme vimos, houve professores que leram só as primeiras páginas ou não leram o material.

Observamos, também, durante a leitura das avaliações, que os docentes que estão em serviço esperam das capacitações aspectos mais práticos e tangíveis para serem aplicados em sala de aula, isto é, tomando em conta o modelo OGEL (ALMEIDA FILHO, 1993, 2007) a materialidade do Método (vide VIANA, 1997), que é a única materialidade que estabelece uma relação síncrona entre professor, pelo desempenho docente, e alunos, pelo desempenho aprendedor.

Em outras palavras, para alguns professores entrevistados, o mais relevante em uma capacitação é mostrar formas de agir perante a turma, sugestões de atividades e formas de explicitar os conteúdos gramaticais de forma que sejam compreensíveis aos alunos. Observamos, também, alguns sinais da abordagem comunicativa ser declarada como abordagem desejada, como objetivo a ser alcançado profissionalmente. No entanto, vemos que a gramática ainda possui uma posição de primazia na hora de pensar em uma aula de PLE idealizada, sobre como transmitir conteúdos “difíceis”, "gramaticais” aos estudantes. Pensa-

\footnotetext{
${ }^{28}$ A autora faz referência ao conceito do Pierre Bordeiu (1991, p. 116 apud BLATYTA, 2009, p. 64): “conjunto de tendências que predispõem os agentes a agir e reagir de determinadas maneiras, gerando práticas, percepções e atitudes que são regulares sem serem conscientemente coordenadas e governadas por regras".
} 
se, ainda, no geral dos entrevistados, de maneira quase generalizada, que o domínio do código linguístico se traduzirá, diretamente, em competência comunicativa.

Por outro lado, em total consonância, os professores entrevistados resgataram a riqueza e a importância da troca de experiências e vivências em sala de aula com os demais professores dos outros CCBs, uma vez que isso permitiu um efeito catártico, de compreensão mútua e um espaço para poder compartilhar situações semelhantes e ver como foram resolvidas por colegas mais experientes.

Os professores do CCBN ressaltam a relevância e a importância do fato de o professor/diplomata Hugo Lorenzetti ter capacitado o pessoal durante a sua estada na Nicarágua. Segundo Aline e o quadro de professores, ele chegou para "revolucionar" a forma de ensino de PLE na embaixada. "O que vocês fazem está bom, mas não é o que se faz atualmente. Por que você está dando listas de palavras? Imagine seu aluno na Avenida Paulista com uma lista de palavras na mão!", foi um dos comentários do professor Hugo descrito por Aline. Assim, ele se reunia com muita frequência com os docentes e os capacitou, segundo nos informaram, com abrangência, rigidez e paciência, sobre os gêneros textuais, assunto que consideram relevante em se tratando de avaliações de larga escala como o CelpeBras.

Lorenzetti fez os trâmites, na sua gestão, para ter uma leitora no CCBN, tempo que foi descrito como "dourado", "ótimo", "fantástico" e "metodologicamente revolucionário" pelos professores do CCBN. Patrícia Nakagome ${ }^{29}$ foi a leitora que chegou ao CCBN em 2008. O leitorado de Nakagome durou 18 meses e teve como produto um artigo publicado como capítulo de livro. "Felizmente, tive a possibilidade de encontrar um interlocutor bastante interessado e prestativo, o diretor do Centro Cultural, com quem discutia as dificuldades rotineiras à luz de nossas experiências profissionais e leituras especializadas". (NAKAGOME, 2012, p. 120). No entanto, encontramos que ambos possuem escassa produção acadêmica na área científica da Linguística Aplicada ao Ensino de Línguas Estrangeiras, e, embora estejam dentro da área das Letras, não possuem formação específica na área do AELin, nem do PLE.

No caso de El Salvador, não houve leitor e na Costa Rica, houve duas vagas abertas leitorados nos anos 2008 e 2010 na Universidad Nacional de Costa Rica. (DINIZ, 2012, p. 60). Não nos foi informado se os leitores tiveram uma relação com a FCDEB.

\footnotetext{
${ }^{29}$ Doutora em Teoria Literária e Literatura Comparada pela Universidade de São Paulo, USP. Currículo Lattes: http://lattes.cnpq.br/6708272847533806
} 
Sobre curso de formação PROFIC, Nakagome (2012, p.122) afirma que uma formação continuada viria, assim, complementar os cursos intensivos: ela possibilita o diálogo sobre os muitos desdobramentos surgidos após o contato com novos conceitos e metodologias. Também, a autora afirma que esses cursos devem ter um processo de autorreflexão, de autoanálise e, para isso, o professor deve reconhecer-se como um profissional, situação que nem sempre ocorre quando o docente percebe o seu trabalho unicamente como fonte de renda. (NAKAGOME, 2012, p. 122-123).

Durante a resenha de teoria, encontramos outra capacitação que não foi comentada nas entrevistas nos países visitados. Morita (2001, p. 49-58) apresenta uma formação continuada por meio de diários dialogados durante um seminário organizado pela Divisão de Instituições de Ensino e Programas Especiais do Ministério das Relações Exteriores para os professores e diretores dos CEBs: Costa Rica, México, Panamá, El Salvador, Venezuela e Nicarágua em julho de 1994. Chamou a nossa atenção que não fosse comentada, e decidimos incluí-la, por contemplar os três países que são o nosso interesse de pesquisa.

Assim, a autora faz uma leitura a respeito da formação docente nesses países. Morita (2001, p. 50), afirma que os professores que entrevistou se sentem valorizados e respeitados, porém, eles enfrentam uma série de dificuldades, pois não está consolidada uma política de profissionalização. Embora houvesse na história do ensino de PLE nos países visitados algumas capacitações, a autora conclui que há uma falta de institucionalização de formação continuada. A autora supracitada apresenta um panorama similar ao que estamos apresentando aqui e ao descrito por Nakagome (2012, p. 119): o perfil dos professores é muito amplo: há alguns com formação superior, outros com formação na área de Letras e há muitos sem formação superior. "Na prática, os professores têm-se feito nas salas na forma de verdadeiros autodidatas, usando seus conhecimentos de outras áreas e/ou do ensino de outras línguas ou da própria intuição". (MORITA, 2001, p. 51).

Assim sendo, a autora vê dificuldades tais como a limitação de material didático e a falta de cursos profissionalizantes para os professores de PLE, e os que houve, ao invés de encorajá-los, estimularam-nos a buscar soluções individuais. Alguns professores, afirma a autora, declararam que se profissionalizaram na própria sala de aula, através da escola da prática. A nosso ver, é por esta razão que eles procuram soluções práticas para a sala de aula, porque a formação do professor de PLE no contexto pesquisado veio da prática, portanto é a que precisa ser, para eles, nutrida e fortalecida.

Portanto, vemos que há uma necessidade de romper o paradigma da capacitação docente: possuir só um componente prático. Deve-se ir gradativamente pensando que o 
professor é um ator completo, que deve refletir sobre a sua prática e ter teoria suficiente para fazê-lo. Assim, concordamos com Morita (2001, p. 53) quando afirma que uma das qualidades do professor de língua estrangeira é que deve ter consciência e criticidade de sua própria prática pedagógica, pois a sala de aula deve ser um local de imensa riqueza para verificar e construir teorias de ensino e aprendizagem. Entretanto, para tal, é necessário que ele tenha uma formação adequada.

Para tal, é imprescindível que haja capacitações de formação continuada para os professores de PLE no exterior. Para o contexto específico, baseados nos depoimentos, deve haver uma mudança de mão dupla: por uma parte, o conteúdo e a linguagem dos cursos deve mudar para ser compreensível para o corpo docente e, por outra parte, o docente deve começar a fazer um processo de autorreflexão, no qual possa se situar no seu papel de agente de ensino, capaz de refletir sobre a sua prática e a prática de outrem.

\subsection{Celpe-Bras e PEC-G/PEC-PG}

Outras ações institucionalizadas que o Itamaraty mantém com os países visitados (e outros) é o exame Celpe-Bras. O exame de proficiência em português brasileiro foi criado por meio da portaria do Ministério da Educação n 1.787/1994 (DA SILVA, 2013, p. 109). Desde o primeiro exame em 1998 até 2015, saltou de 127 a mais de 5 mil candidatos na edição 02/2015 $5^{30}$. Em 2009, o então Ministro da Educação, Fernando Haddad, determinou que, a partir do segundo semestre do mesmo ano, o Instituto Nacional de Estudos e Pesquisas Educacionais Anísio Teixeira (INEP) seja o responsável pelo exame.

As instituições visitadas pertencem ao grupo de 58 postos credenciados para aplicar o exame no exterior. Entramos em contato com o INEP para saber os resultados das aplicações do exame desde o ano 2009 até o ano 2015. Fomos informados que não era possível fornecer os resultados dos participantes, visto que se tratam de informações pessoais que, de acordo com a lei de acesso à informação (Lei $n^{0} 12.527$, de 18 de novembro de 2011), são de acesso restrito aos interessados. Assim, apresentamos o número de inscrições homologadas nos postos do Celpe-Bras de El Salvador, Nicarágua e Costa Rica, nos anos mencionados:

\footnotetext{
${ }^{30}$ Disponível em: < http://www.brasil.gov.br/educacao/2014/08/celpe-bras-mais-de-5-mil-candidatos-realizaraoexame-de-proficiencia $>$ Acesso em 10 dez. 2015.
} 


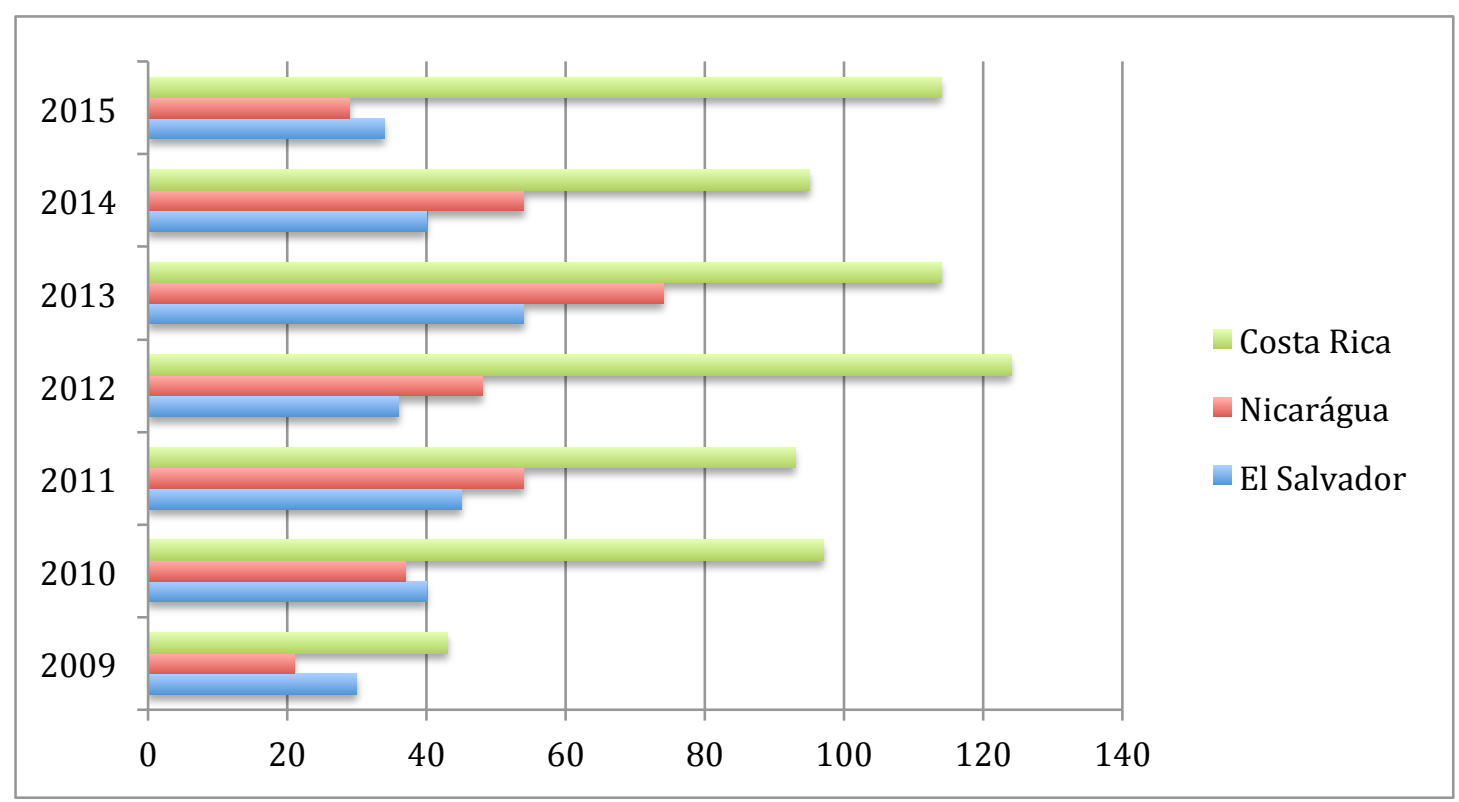

Gráfico nosso, informações do Sistema de Acesso à Informação do INEP

A procura do exame Celpe-Bras, como observado no gráfico, é maior na Costa Rica, com um salto de 43 a 114 inscritos nas aplicações do ano 2009 e 2015 respectivamente; em El Salvador, vemos um número que se mantém relativamente estável (30 e 34 nas aplicações de 2009 e 2015) e na Nicarágua, observamos a mesma estabilidade (21 e 29 nas mesmas aplicações).

Segundo foi informado, as três instituições oferecem cursos preparatórios do CelpeBras e, conforme apresentado no gráfico, a procura pelo exame é bastante significativa tomando em consideração o tamanho do país e a quantidade de alunos por período letivo. Sobre isso, quisemos perguntar sobre a quantidade de alunos que procuram o português Apresentamos, como exemplo, os dados do primeiro período letivo do ano 2015 das instituições dos países visitados: 
GRÁFICO 4: ALUNOS PLE INSCRITOS NO PRIMEIRO PERÍODO LETIVO 2015: CCBES, CCBN, FCDEB

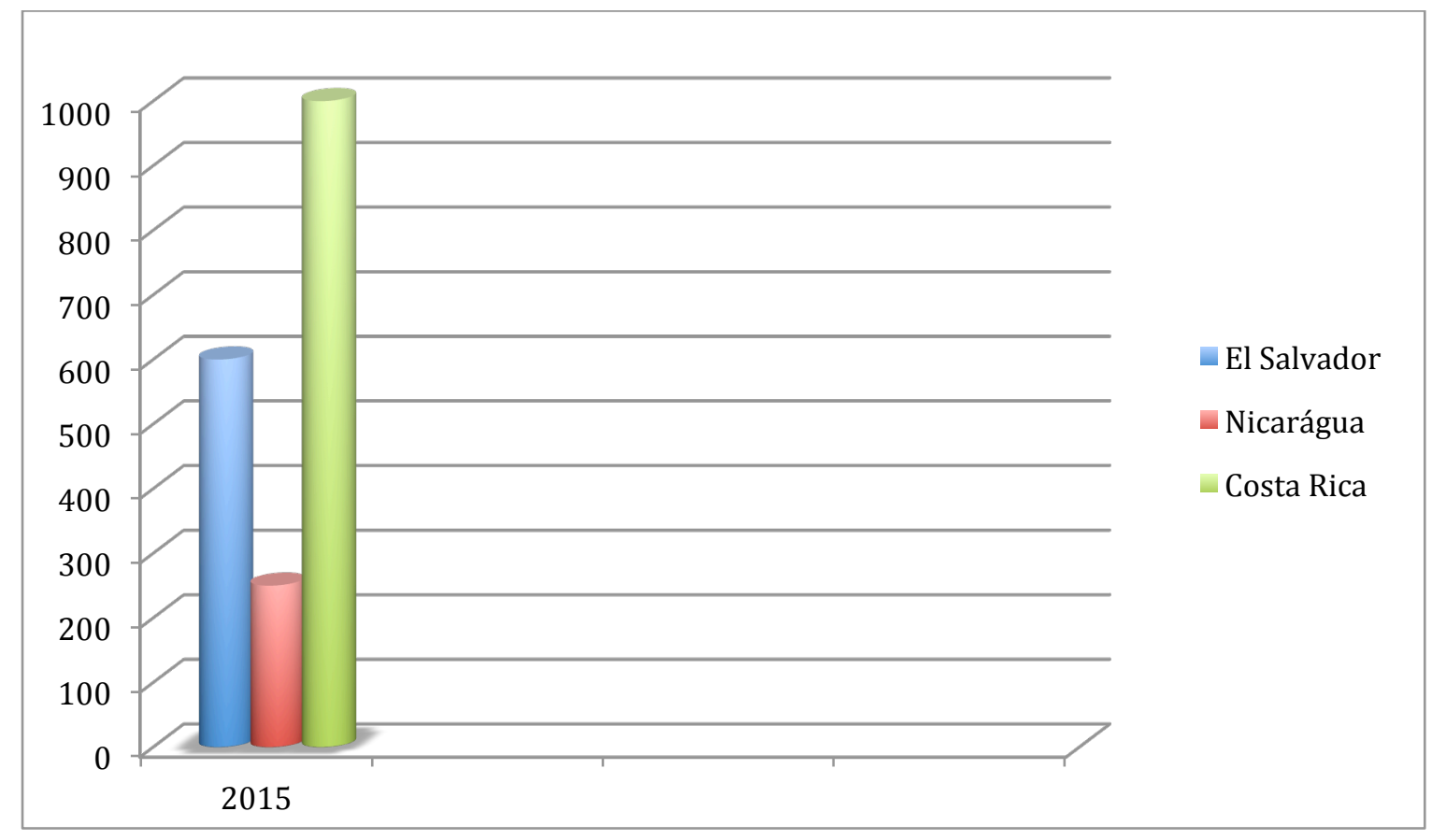

Gráfico nosso

Como exposto no gráfico anterior, vemos que a quantidade de alunos nas três instituições é significativa: mais de 1000 na Costa Rica ( $1^{\circ}$ bimestre), $650 \mathrm{em}$ El Salvador ( $1^{\circ}$ trimestre) e 250 na Nicarágua ( $1^{\circ}$ bimestre). Só o último país mencionado tem um número relativamente pequeno de alunos, se comparado com as outras dois instituições. Aline afirmou que a localização do CCBN é um empecilho para não aumentar o número de discentes, pois a embaixada fica longe do centro de Manágua.

As instituições de El Salvador e Costa Rica, como exposto no gráfico, têm um número alto de alunos a cada período letivo, quantidade que, segundo nos informaram, tem-se mantido ao longo dos últimos 5 anos. Ana Lourdes, uma das diretoras da FCDEB afirmou que as duas sedes não dão conta da quantidade de alunos que estão à procura do português ${ }^{31}$ : "está nos nossos planos abrir um novo local, ou aumentar a oferta de horários, porque os espaços não estão dando conta", afirmou. No caso do CCBES, Fátima, no mesmo sentido, disse que não abrem mais vagas porque não há professores e porque a infraestrutura não permite receber mais alunos.

${ }^{31}$ O FCDEB possui duas sedes, uma em San José (capital da Costa Rica) e outra a 15 quilômetros, na cidade de Santa Ana, (23 minutos, sem trânsito). 
Essa procura expressiva pelo português e pela busca de aferir os conhecimentos da língua portuguesa por meio do exame Celpe-Bras tem uma resposta: o português não é mais uma língua de turismo, ou de lazer. Nos países visitados, segundo os depoimentos, nunca o foi, como é no caso da Nicarágua, de El Salvador e da Costa Rica. Durante as entrevistas, foi nos informado que nos três países há call centers que pedem proficiência em português e os professores dos centros pesquisados são chamados para ir e oferecer treinamento de pronúncia, coaching, correção de redações, etc. Segundo Aline, Fátima e Susana, o português é uma "muito procurada" terceira opção (de língua) para aqueles que querem acrescentar suas opções laborais e aumentar o salário. Em outros casos, uma terceira língua é requisito de formatura de algumas universidades privadas, como no caso de El Salvador.

Durante a nossa permanência in loco, conversamos com Nicolás Ayala, historiador da educação, pesquisador da área de inglês como língua estrangeira da Universidad de El Salvador, (UES), e coordenador do curso de Lenguas Modernas. Na entrevista, ele comentou que pretendem esboçar uma proposta de adicionar o português brasileiro ao currículo do curso que ele coordena, pois houve uma pesquisa de conclusão de curso no ano 2015, na qual: “os jovens descobriram que, depois do inglês, a língua do comércio e do turismo nas praias de El Salvador é o português brasileiro e não o francês". O anterior reafirma a necessidade de maior difusão da língua portuguesa e mais capacitação de docentes especializados na área. E afirma o que fora dito antes nesta dissertação: instituições podem e contam com a autonomia de criar e implantar políticas linguísticas.

No caso da Costa Rica, Susana afirmou que é muito comum encontrar costarriquenhos que dominem de forma ampla a língua portuguesa e que a mão de obra tica ${ }^{32}$ é de alta qualidade. Esse argumento reforça a pesquisa desenvolvida por Pires no ano 2013, que afirma que: a mão de obra é de alta qualidade e que houve uma propaganda para empresários investirem nos call centers da Costa Rica, pois com um salário que poderia ser pago a um americano, pagar-se-iam três salários a costarriquenhos, graças aos Tratados de Livre Comércio assinados por ambos os países. (PIRES, 2013, p. 22). Constatamos, também, que o autor afirma que um dos motivos de os costarriquenhos aprenderem português é que há uma diferença bastante chamativa entre o salário dos centros de atendimento em português e um professor universitário local. O autor fez a comparação e afirmou que um agente de atendimento ao cliente com fluência em português poderia receber $\$ 400$ dólares americanos a mais do que um professor universitário. (Vide ANEXO H).

\footnotetext{
${ }^{32}$ Gentílico de uso popular para costarriquenho, seu uso não é pejorativo.
} 
Constatamos, também, nas entrevistas feitas, o Brasil apresenta-se, unicamente, como um destino importante para estudos de graduação e pós-graduação e, assim, ter um crescimento profissional. Como mostrado nos depoimentos, no caso da Nicarágua, o propósito de os alunos irem às aulas de português é aprovar o Celpe-Bras e obter uma bolsa de estudos do governo brasileiro. No caso de El Salvador e da Costa Rica, ocorre da mesma maneira. A esse respeito, no que concerne às instituições visitadas, encontramos duas grandes limitações: a falta de capacitação no que diz respeito à avaliação do Celpe-Bras e a falta de preparação dos docentes para informarem os interessados sobre os Programas de Estudante convênio PEC-G e PEC-PG ${ }^{33}$.

Em uma das entrevistas, consideramos que o depoimento de Maria traduz de forma fiel o sentimento dos professores sobre a necessidade de formação e capacitação sobre o exame:

\begin{abstract}
Maria: nós fazemos o Celpe-Bras, queríamos nós ser convidados e ir até Brasília e ver como corrigem, de que maneira eles dão as notas, porque os alunos perguntam. $\mathrm{Na}$ nota oral a gente dá, mas não sei como é o equilíbrio que eles fazem nas provas oral e escrita para equilibrar a nota do aluno. Acho que nossa diretora deve ser convidada para saber como é feita a correção e passar pra nós isso. Porque não sabemos se estamos longe dos ensinamentos adequados para o aluno. Quanto mais a gente souber de que maneira Brasília faz a sua programação no sentido de como corrigem as provas, a gente vai ser mais exigente, o professor vai buscar mais, aprimorar, explicar melhor.
\end{abstract}

Em consonância sobre a capacitação do Celpe-Bras, Aline comenta, ainda:

\begin{abstract}
Aline: Todos os anos a gente pede coisas muito mais simples do que uma capacitação: vamos lá, correção do Celpe Bras, você sabe como faz? Não. E você? Também não. Vamos lá, a gente precisa aprender, pelo menos fazer um estágio, vai lá, minha filha, e traz café, eu vou e trago café, mas deixa eu aprender e olhar, eu não tenho problema se ficar aí, fazendo as unhas dos outros, posso ficar segurando os casacos de todo mundo, eu viro cabide (risos), mas ninguém sabe. Então vêm aquelas coisas, né? A gente aplica prova, tá? Desde 2005 eu aplico prova do Celpe. $[\ldots]$

A nossa obrigação é pegar a prova, a gente coloca... faz, lacra e manda. A gente realmente não toca, tá certo? Mas, lógico, eu passei as notas, eu passei o áudio em .mp3 ou .mp4, tá? E eu escutei como essa pessoa falou ou, talvez, eu fui a professora/entrevistadora, aí eu fíco: nossa, coitado! Se ferrou! Aí aparece com Intermediário Superior... COMO? O que é que eu, no meu entendimento, estou
\end{abstract}

\footnotetext{
${ }^{33}$ Os Programas de Estudante Convênio de Graduação (PEC-G) e de pós-graduação (PEC-PG) são programas que foram criados com o objetivo de possibilitar a cidadãos oriundos de países em desenvolvimento a realização de estudos de graduação e pós-graduação em Instituições de Ensino Superior (IES) brasileiras, contribuindo, assim, para a formação de recursos humanos. O programa é administrado pelo Ministério das Relações Exteriores, por meio da Divisão de Temas Educacionais, e pelo Ministério da Educação, em parceria com Instituições de Ensino Superior em todo o país.

Cabe mencionar que as três instituições visitadas são as encarregadas de dar as informações sobre os convênios mencionados.
} 
vendo errado que a outra pessoa lá em Brasília viu diferente ou o que é que está pesando mais? O que é que ele fez? Não é? Então, quer dizer, eles precisam passar para nós, professores, o entendimento de quais são as suas regras, os critérios para avaliar.

Vemos, então, que alguns critérios e/ou procedimentos do Celpe-Bras (estrutura, grades de avaliação, avaliação holística ou analítica, peso e critérios de avaliação) ainda são desconhecidos para os professores. O mesmo pensamento foi percebido nos comentários das instituições de El Salvador e da Costa Rica, também no sentido de material preparatório. Deve-se pensar, então, em capacitações do corpo docente sobre o exame e sobre os programas PEC-G e PEG-PG. A esse respeito, Juliana S. e Aline comentaram:

\begin{abstract}
Aline: cursos de atualização para os agentes operadores dos Programas de bolsa PEC-G e PEC-PG, somos nós que damos a informação, a gente começava a ligar, pega tudo o que está na internet, de repente vem alguém que sabe um pouco mais e você começa a aturar essa pessoa de informação: vem cá, me explica como é isso ou aquilo. E a gente dá seguimento, quer dizer, a gente chega inclusive aqui, o aluno se complica tanto criando curriculum vitae no $\mathrm{CNPq}$, e depois o Currículo Lattes, depois não sei o quê, aí ele marca uma hora conosco, sentamos aqui e vamos lá, toca fogo. Aí a gente vai com ele. Mesmo assim, a gente consegue, por exemplo, a gente acaba de enviar quatro pessoas, quatro pessoas, para o PEC-G. Não é uaaau, mas o fluxo não é grande, mas sempre tem dois ou três nicaraguenses ao ano que vão. Tem certo nível de competência nossa, quer dizer, a gente se transforma em certos atores de que realmente a bolsa tá funcionando.

Juliana S: O principal problema que vejo é a burocracia. Todo o processo que as pessoas têm que fazer para participar no programa. Também, o domínio da língua respaldado pelo Celpe-Bras acho que é um dos problemas para que as pessoas não se inscrevam. Ademais, as pessoas que não estão aqui desconhecem o PEC-G. Não tem muita divulgação. Nos anos que estou coordenando o PEC-G, nunca tivemos uma capacitação sobre o programa. O que eu sei foi que li, me informei. O ministro anterior que estava na embaixada tinha trabalhado com os programas e ele nos deu algumas orientações. Porém, falta divulgação, capacitação. Tem muita gente que pede informação, mas quando eu digo que precisa do português, desistem.
\end{abstract}

Se formos comparar o número de alunos inscritos nos curso de português e a procura pelo exame Celpe-Bras, observamos que a quantidade de pessoas beneficiadas dos programas PEC-G e PEC-PG é menos expressiva. A seguir, mostramos o relatório da Divisão de Temas Educacionais do Ministério das Relações Exteriores dos anos 2000 a 2015: 
TABELA 9: PEC-G SELECIONADOS AMÉRICA LATINA E CARIBE 2000 A 2015

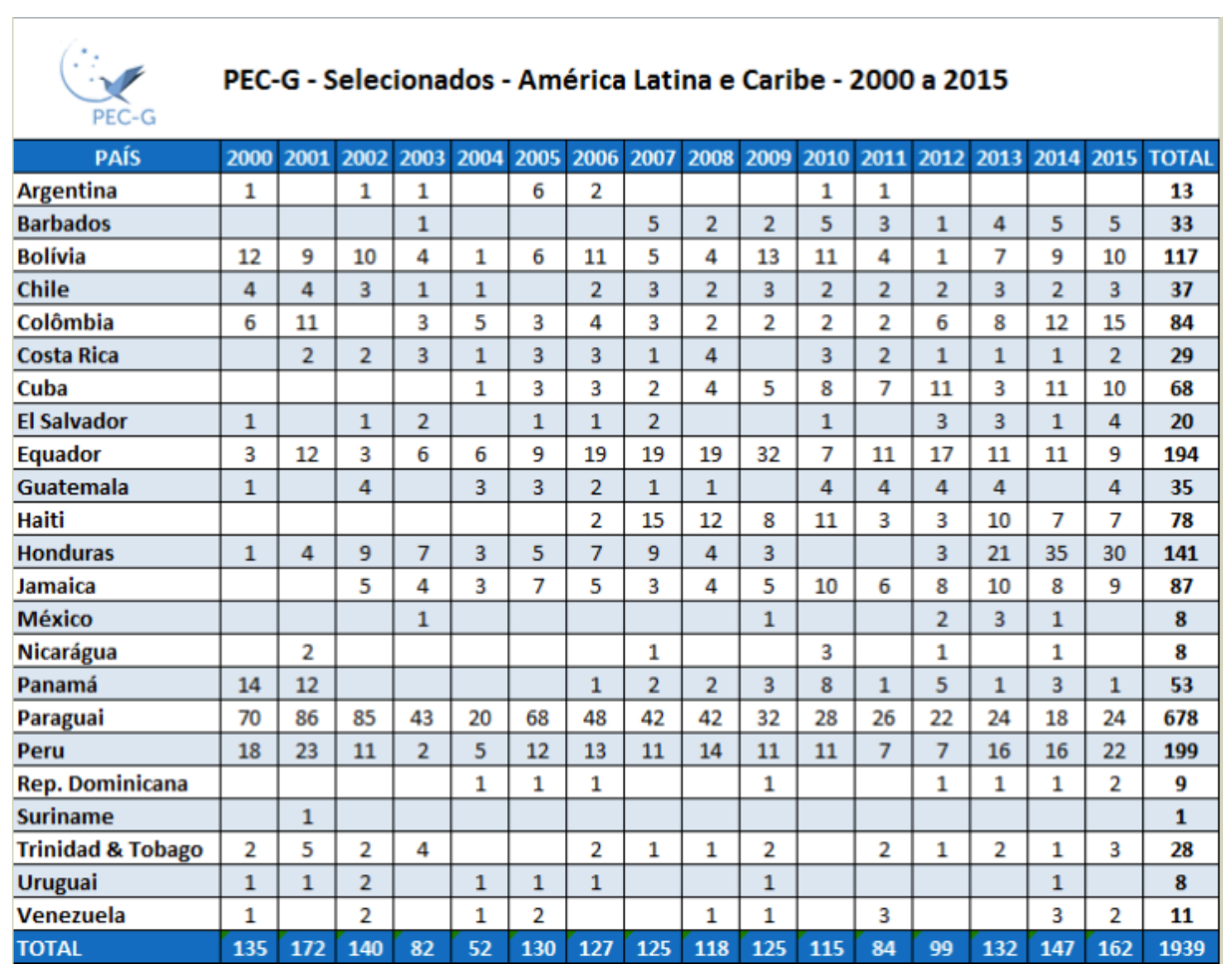

Fonte: Divisão de Temas Educacionais, MRE, 2015

TABELA 10: PEC-PG SELECIONADOS AMÉRICA LATINA E CARIBE 2000 A 2013

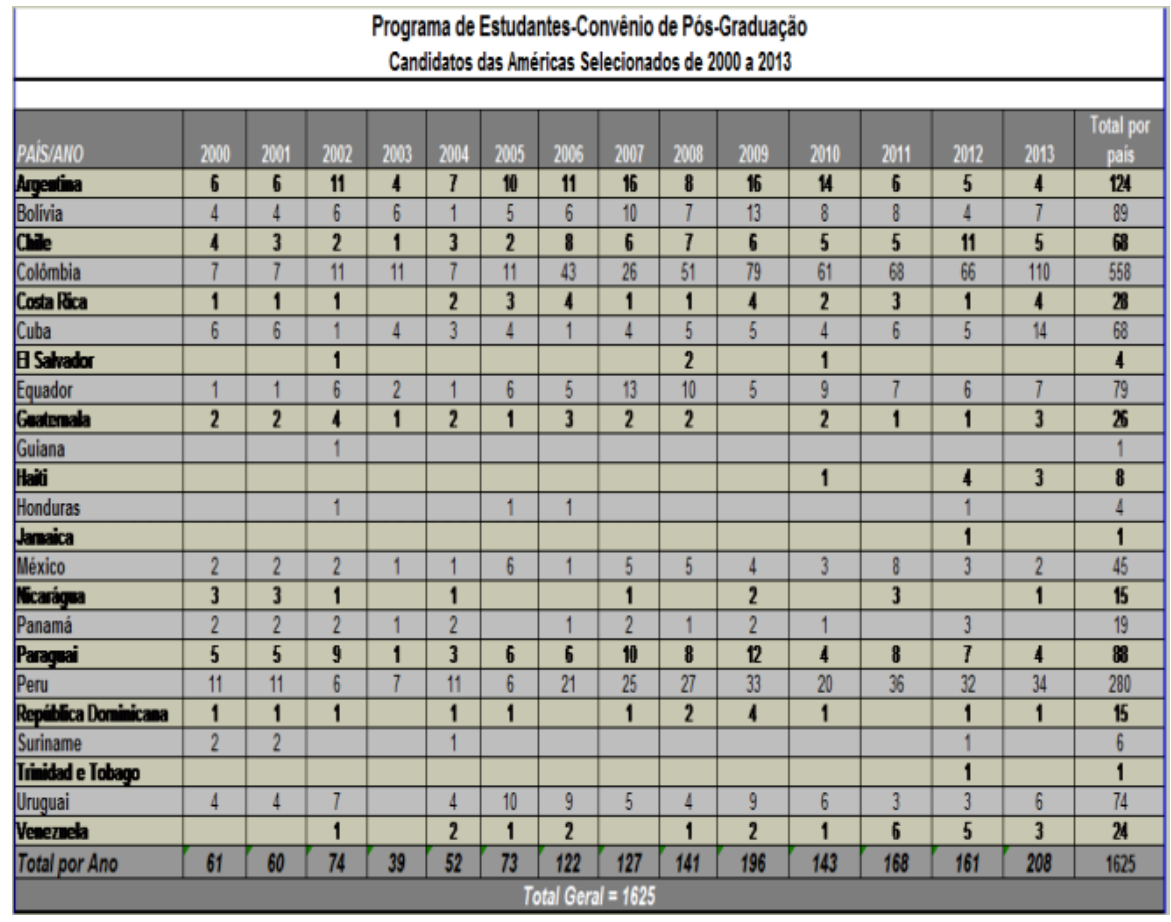

Fonte: Divisão de Temas Educacionais, MRE, 2015 
Como observamos nas imagens anteriores, a quantidade de alunos aprovados nos programas PEC-G e PEC-PG vindos dos países visitados não é tão grande quanto os alunos que buscam estudar português ou os que fazem o Celpe-Bras. Juliana S. afirma que uma das razões poderia ser porque, além da aprovação obrigatória do Celpe-Bras, o PEC-G impõe idade limite para participar: ter entre 18 a 23 anos completos ${ }^{34}$. Para o PEC-PG, encontramos também, que deve ter a aprovação no exame e "ser aceito por Instituição de Ensino Superior brasileira (IES), pública ou privada, em curso de mestrado ou doutorado avaliado pela CAPES com conceito igual ou superior a 03 (três)" ${ }^{\prime 35}$.

Como apresentado nas imagens, vemos que a quantidade de alunos enviados graças aos programas PEC-G e PEC-PG é a seguinte: de 2000 a 2015, foram aceitos para participarem do programa PEC-G: 20 salvadorenhos, 29 costarriquenhos e 8 nicaraguenses. Para o Programa PEC-PG, de 2000 a 2013, foram aprovadas as solicitações de: 28 costarriquenhos, 4 salvadorenhos e 15 nicaraguenses.

Destarte, para aumentar o número de participantes, as professoras Juliana S. e Aline manifestaram que é necessário que haja capacitações tanto do Celpe-Bras como dos programas de estudante convênio, pois a informação que elas conhecem é, na maioria das vezes, encontrada na internet, em sites não oficiais. Embora elas afirmem que enviam perguntas ao e-mail oficial da Divisão de Temas Educacionais para obter algumas respostas, é mister que haja mais informação a respeito de tais ações do governo brasileiro.

Além das ações de iniciativa governamental para os Centros de ensino de PLE fora do Brasil, observamos que há uma necessidade de fazer convênios e eventos internos de diversa natureza a fim de promover a língua e cultura do Brasil. A totalidade dessas ações não foi iniciativa do Itamaraty e, sim, da gestão das instituições visitadas. A seguir, apresentamos um breve resumo delas.

\footnotetext{
${ }^{34}$ Disponível em: http://www.dce.mre.gov.br/PEC/G/criterios candidatura.html Acesso em 10 de out. 2015

${ }^{35}$ Disponível em: http://www.dce.mre.gov.br/PEC/PG/candidatura.php Acesso em 10 de out. 2015. Esse ponto, especificamente, é muito discutido em blogs e sites não oficiais de informação do programa. Alguns sites recomendam aos alunos virem ao Brasil como turistas para obterem essa carta de aceite, e depois que façam o processo para participar do programa PEC-PG.
} 


\subsection{O alcance dos centros de ensino de PLE visitados}

\section{EL SALVADOR}

Convênio com a Policía Nacional Civil (PNC): bolsas aos estudantes da PNC, que são oficiais que trabalham patrulhando a cidade ou têm função administrativa. Esse convênio se estende para os familiares diretos deles: esposa (o), filhos. Segundo William Saul González, Coordenador da Área de Gestión Formativa Centro Formación y Capacitación Institucional, o convênio iniciou com a Dra. Vanda Pignato, no ano 2002. Houve, no total, mais de 150 estudantes desde o início do convênio. A seleção dos agentes é baseada no cargo e gênero, tendo como uma das prioridades a equidade de gênero. William González afirmou que já houve agentes que foram a países em conflito ou em colaboração com as Nações Unidas graças ao português: Timor-Leste e outros a países de língua oficial inglesa.

Convênio com o Ministério das Relações Exteriores: Este convênio se cristaliza no Instituto Especializado de Educación Superior para la Formación Diplomática (IEESFORD) que começou em 2012, no qual os professores do CCBES vão ao Ministério dar aulas de português para os diplomatas. Segundo o contador do CCBES, já se formaram mais de 30 estudantes.

Convênio com o Centro Nacional de Artes, CENAR: o convênio é oferecer oficinas de teatro para os alunos e, desse modo, os professores de artes cênicas recebem uma bolsa para aprenderem português. O convênio iniciou em 2013 e atualmente tem dois alunos recebendo aulas.

Convênio com Fuerza Aérea de El Salvador (FAES): Existe um convênio que iniciou em 2014 e outorga 4 bolsas de estudo a cada trimestre letivo.

\section{Convênio com Universidad Francisco Gavidia (UFG) e Universidad de El Salvador} (UES): no caso da UFG, o convênio iniciou em 2009 com os alunos do curso de relações internacionais. Eles fazem um estágio no CCBES de seis meses e, em troca, eles recebem uma bolsa para aprender português. O convênio com a UES é mais recente, iniciou em 2014 com 6 estagiários e 4 em 2015. 
Carmen Rodrigues teve um programa chamado Hola, Brasil, na Radio Clásica e o Brasil Contemporáneo durante seis anos na Radio Láser, nos anos 90. Há pouco tiveram um programa de rádio financiado pelo Itamaraty, Alma Brasileira, no ano 2011, de difusão da cultura brasileira: música, palavras em português, cultura e culinária. Segundo comentaram as professoras, algumas são chamadas para cozinhar na televisão, dar entrevistas para as rádios. Atualmente a professora Carmen trabalha com a NatGeo, na área de legendagem, fazendo as traduções português-espanhol dos documentários.

\section{NICARÁGUA}

Exército Nicaraguense: segundo o administrativo do CCNB, o convênio iniciou em 2013. Outorgam-se bolsas de estudos, no momento em que a pesquisa foi feita (início do ano 2014) havia quatro alunos, do exército um aluno no Básico II e três alunos no Intermediário II, todos com bolsa integral. Afirmou, também que há 16 alunos que cursaram o básico I, e um dos professores vai ao exército duas vezes por semana.

Há bolsas para alunos regulares, sendo a maioria familiares dos funcionários da embaixada. Os alunos regulares têm acesso a bolsa, mas é menor quantidade. No quadrimestre em que foi feita a pesquisa havia 20 alunos com bolsas, entre o exército e alunos regulares.

Funcionários do governo nicaraguense, diplomatas: há funcionários do governo da Nicarágua e pessoas de outras embaixadas que solicitam aulas de português. Também os membros da Cooperação Japonesa, Japan International Cooperation Agency, (JICA) faziam aulas via Skype.

Português como Línguas de Herança (PLH): Começou no ano 2013 um projeto piloto de PLH, começou um projeto chamado Conta Contos.

\section{COSTA RICA}

Aulas para pessoas com capacidades especiais: Aulas de português para duas pessoas com Síndrome de Down, e para um cego.

\section{Aulas para crianças em favelas:}


Um dos professores dá aulas em uma das maiores favelas do país (chamadas de cantones), ele vai dar aulas para dois grupos, um de alunos do primeiro nível, e o grupo de crianças iniciantes.

A iniciativa surgiu de uma das diretoras, segundo a professora Mércia. As crianças, salientaram os entrevistados, não pagam nada e recebem lanche. A parceria é feita com uma ONG chamada SIFAIS.

\section{Aulas para presidiários}

Uma das professoras sentiu essa necessidade de ajudar, então ela ia para a prisão e conseguiu formar um grupo. Mércia comentou que tem um vídeo no Youtube que a mostra indo à prisão e um dos alunos falando em português com ela. Mércia afirmou que tem muito orgulho de comentar sobre essas ações porque nascem dos professores, asseverou que eles sentem essa felicidade de ajudar as pessoas para que, por meio da educação, eles consigam um melhor futuro.

\section{Exposições de artistas costarriquenhos inspirados no Brasil}

A instituição faz parte do Arte City Tour, que é uma atividade organizada para que o público geral, a cada dois meses, possa visitar vários lugares que realizem eventos culturais. A última exposição que tiveram tinha o tema era "Favelas", e 12 artistas nacionais fizeram trabalhos inspirados na favela e houve uma exposição nesse dia.

Como observamos, há um leque bastante amplo de ações que as três instituições visitadas fazem para promovera a língua e a cultura do Brasil. Uma resposta unânime veio de todos os entrevistados quando perguntamos sobre capacitações para crianças e pessoas com capacidades especiais: deve haver capacitação, sim. Vemos, pois, que há muito trabalho que está sendo feito; todavia, há muito mais por fazer. 


\section{CONSIDERAÇÕES FINAIS}

Concordamos com Almeida Filho (mimeo, 2015), quando afirma que estabelecer políticas tem relação com a visão de país, com o projeto nacional e com a capacidade de gestão daquela nação. O autor afirma que "políticas são projetos discutidos, aprovados com detalhamento e dotados de meios ou recursos para serem levados a bom termo" (ibidem) e, ainda, declara:

\footnotetext{
Uma política resulta de uma decisão tomada em alguma instância de poder a que se faculta lançar chamada para que se constitua uma equipe com diretrizes. Um plano de metas pode escalonar iniciativas em etapas numa ordem que seja orgânica e factível para o orçamento. Metas de curto, médio e longo prazos são uma estratégia racional para avançar em mais de uma frente simultaneamente ou numa sequência mais ágil.
}

O autor destaca uma organização, planejamento e sequência daquela política que se deseja instalar. O autor acrescenta, ainda, que o conhecimento da História do Ensino de Línguas no país será instrumental para a proposição de políticas e sua argumentação. Destarte, podemos resumir, partindo do estudado e analisado e da tabela apresentada no início do embasamento teórico, que parte de uma política (oficial, de Estado) para o PLE deve ser a institucionalização dessa língua como estrangeira (LE/L2) no exterior por meio de: 1) criação de lugares de aprender PLE e cultura brasileira, escolas e centros binacionais (como o caso dos CCBs), leitorados junto às universidades. 2) Contratação de professores de PLE (localmente, no Brasil, via concurso formal, mediante apresentação de currículo, por indicação, com critérios formais, exigência de formação universitária adequada ou com exigência de competência comunicativa básica; 3) Escolha e produção de materiais didáticos; 4) implantação de um exame internacional e aplicado de língua; 5) consciência e deliberação na formulação de uma política para o PLE por parte de sucessivos governos.

Assim, observamos que os quesitos mencionados, vemos que, sob um recorte sincrônico e diacrônico, apresentam-se desafios perante às decisões feitas pelo governo brasileiro. Reconhecemos os esforços ao longo da história de promover a língua e cultura no Brasil nos Centros de ensino espalhados no mundo, apesar de termos demonstrado que a instalação de centros de ensino (CCBs) parte de interesses que, às vezes, não vão ao encontro da promoção do PLE mundo afora. A escolha e produção de material didático dá-se pela visão do professor que "é isso que os alunos precisam", e vemos que há, ainda, uma tendência de 
privilegiar materiais didáticos com denso conteúdo gramatical. É o domínio das regras do código linguístico que toma as rédeas do ensino nos países visitados, embora estabeleça-se a abordagem comunicativa como um horizonte ou um desejo das pessoas encarregadas de difundir o português nos países visitados. A implantação do exame de proficiência parece-nos um ponto positivo e pulsante, o Celpe-Bras é uma realidade nos países visitados, com demanda crescente na Costa Rica, e com certa estabilidade em El Salvador e na Nicarágua. Sobre a consciência dos sucessivos governos, os depoimentos do linguista aplicado Almeida Filho parecem-nos esclarecedores sobre o panorama de implantação de políticas oficiais: embora existam ações institucionalizadas, a alta rotatividade dos encarregados de promover, criar, observar e implantar políticas têm uma rotatividade muito grande, e falta uma equipe profissional (formada $n a$ área) dentro da área encarregada no órgão governamental.

Dos cinco itens apresentados, o que quisemos destacar foi o de formação de professores de PLE. Como demonstramos, 3 professores do universo de 48 pertencem à grande área de Letras. Apesar das condições locais e governamentais do Brasil, houve esforços significativos de tentar instalar um programa orgânico-sistemático de formação continuada de professores de PLE com uma filosofia reflexiva, sob o arcabouço teóricometodológico da abordagem comunicativa.

Assim, os professores de línguas não-formados (a grande maioria nos CCBs), mesmo os formados em áreas afins, são admitidos para trabalhar. Não existe a possibilidade de exigir formação na área, pois os concursos ou a contratação nem sempre é padronizada, conforme vimos na apresentação de resultados.

Vemos, também, a ação/influência das forças propostas por Almeida Filho (2014) no que diz respeito ao panorama de ensino de PLE nos lugares visitados cristalizada no volume baixo de cursos formação dos docentes. Reconhecemos que não é fácil formar professores em serviço, pois eles, geralmente, vivem em uma tradição consolidada por um lado (e difícil de ser colocada em crise, no dizer de BLATYTA, 2009) e com trajetória fugaz nas instituições (casos de alta rotatividade dos Centros).

Assim, a (pouca) formação recebida é, em geral, errática, não-sistemática, não na estrutura per se da capacitação recebida, mas na continuidade, que não dependia dos planejadores do curso. Um sólido planejamento de cursos de formação continuada contemplaria um plano geral, desembolso por parte da instituição do governo, uma estante de leituras que ajude a formar um imaginário propício à superação, seguimento daqueles que recebem cursos intensivos de formação, uma formação baseada em princípios defensíveis, tudo isso para se alcançar resultados compensadores. 
Em um modelo adverso à melhor formação que se pode ofertar por meio de cursos esporádicos e intensivos de formação dita continuada, o mais lógico, acreditamos, é montar um esquema prático de treinamento: observar professores experientes e tidos como bemsucedidos ensinando por um tempo e iniciar intervenções guiadas (aulas planejadas em conjunto com um treinador), aulas ensinadas com observador que corrija e faça sugestões.

Por outro lado, apresentaremos algumas considerações a respeito dos cursos recebidos. A primeira questão que surge é que os cursos de formação são "muito teóricos". O embate surge nesse ponto, pois os professores vivem num presente eterno da prática e para eles é o único que deve ser discutido e sobre o que deve haver reflexão. Concordamos com Almeida Filho (2013) quando afirma que:

\begin{abstract}
A formação reflexiva não pode impor um modelo ou método formativo e passar a treinar nele os professores postos em formação. Acompanhamos Prabhu (1990) na hipótese mais provável de que não há inicialmente o melhor método para ensinar (e para aprender, acrescentaria eu) e de que os professores são tão múltiplos e diversos quanto o são os contextos nacionais e regionais. No exercício da profissão de ensinar línguas, eles/elas se reconhecem no ensino que produzem e se apropriam de meios para uma análise justa do que fazem (o procedimento reflexivo apoiado numa filosofia reflexiva). Pode surgir das leituras teóricas adequadas e das discussões com um Outro formador o desejo de ensinar de determinada forma, em determinada direção. Nesse caso, o professor se assegura do que compreende o processo e vai buscar transformações embasadas que serão outra vez objeto de indagação e interpretação analítica num ciclo que se renova.
\end{abstract}

Afirmamos que sem teoria (relevante) não há formação séria possível. Barçante (1999, p. 26) afirma que o professor sempre refletiu a sua prática, mas sem teoria a sua reflexão "poderia ser considerada assistemática, sem o interesse investigativo de que reveste hoje, ficando restrita a ele mesmo ou a eventuais conversas entre colegas na busca de soluções imediatas" (op. cit.). Assim sendo, a teoria só se encaixa na formação se houver um plano formador de longo alcance, como o descrito nesta dissertação. Se isso não estiver, não parece haver energia para investimento numa "carreira". Os professores, muitos deles, conforme observamos, são de outras áreas e estão no ensino de PLE por razões práticas, como a sobrevivência financeira, por exemplo.

A segunda próxima questão é da mudança de filosofia de abordagem de ensino da gramática como grande organizador das práticas para uma espécie de comunicativização de forte base gramatical e, depois, para uma abordagem comunicativa plena na qual a explicitação da forma é lateral, secundária. Saber que existe alternativa para o ensino gramatical seria um passo a valorizar, como foi transcrito em alguns depoimentos dos professores na avaliação escrita do curso de formação continuada. 
No entanto, a passagem do tempo fez com que os docentes perpetuassem o seu presente contínuo de práticas e fórmulas da execução do trabalho que propiciam que se acostumem com a prática e não coloquem em xeque seu exercício profissional por meio de reflexão baseada em teoria da área, limitando o ensino encaixado nas crenças, "loucuras", como foi dito nos depoimentos, ou tradições consolidadas.

A maioria de depoimentos apresentados nas entrevistas apresentam inconsistências conceituais, como pensar que o ensino de LE é semelhante ao ensino de L1 para crianças; outros apresentam a primazia que a prática deve(ria) ter nesses cursos de formação continuada: só a prática satisfaria as demandas dos docentes, o que foi demonstrado com alguns comentários que evidenciaram a falta, pouca ou inclusive nula leitura dos textos recomendados no decorrer dos cursos. Embora nos questionários apareceu a palavra "revolucionário" para se referir a abordagem comunicativa, um dos depoimentos reconhece que já "sabia" o conteúdo da capacitação e alguns a qualificaram como "positiva", e principalmente, houve uma valorização quase absoluta no momento de os formadores oferecerem dicas, práticas, e ideias para a sala de aula.

Após essa pequena análise, o que quisemos mostrar foi um panorama sincrônico e diacrônico da situação do ensino de PLE em três países da América Central: El Salvador, Nicarágua e Costa Rica. Retomamos informações históricas e oficiais para evidenciar os traços históricos das grandes ações reconhecidas pelo governo brasileiro para a difusão da língua portuguesa mundo afora. Assim, os Centros Culturais Brasileiros, os Leitorados, o Exame Celpe-Bras, os programas de Estudante Convênio de Graduação e Pós-Graduação, são as ferramentas de diplomacia cultural que o Brasil mantém com o exterior. Essa política, conforme vimos anteriormente, depende das prioridades do governo do Brasil e das relações que o país tem com as demais nações. Vimos, também, que uma prioridade é a difusão da cultura, privilegiando-a sobre a formação de professores de português.

Retomando o que foi mencionado no capítulo teórico, a história do ensino de línguas deve ter como objetivo iluminar o passado para que entendamos, em parte, como é atualmente (HOWATT, 2004). Assim, nessa compreensão, podemos evitar os erros do passado para não cometê-los novamente, no dizer de Bloch (2001). Tentamos, assim, esboçar uma história que pudesse criar laços entre o passado e o presente, nas palavras de Farge (2011).

Desse modo, vemos que, historicamente, a política de difusão linguístico-cultural do Brasil, pelo menos presente nos países visitados, privilegia alguns aspectos como a infraestrutura, os eventos de natureza cultural, as condições físicas para o andamento das aulas, porém, não reconhece como essencial a formação dos professores em exercício. 
Chegamos a esta conclusão pelo baixíssimo volume de capacitações aprovadas e dadas nos CCBs visitados em comparação com o tempo dos professores em serviço de docência de PLE.

Assim, conforme vimos, há professores com mais de 30 anos em sala de aula e unicamente três capacitações na área do aprendizagem e ensino de português como língua estrangeira. Este cenário, segundo Almeida Filho, é recorrente em instituições como o Centro Cultural Brasil-Paraguai (grifos nossos):

\begin{abstract}
Quando eu comecei com os professores no Paraguai, eles me disseram: professor, o instituto está desde 1942 sem capacitação. Foi quando eles começaram, durante a guerra, em Asunción. [...] Eles me disseram também: "nós tivemos só um PROFIC, não foi como este, não era tão sistematizado". Tiveram só 1 entre os anos 40 e o segundo no ano 87 ou 89, mais ou menos. Olha quanto tempo passou, quase 40 anos.
\end{abstract}

Em outros casos de CCBs, o panorama é diferente. No caso do Centro Cultural BrasilPeru (CCBP), por exemplo, o acadêmico acrescentou, ainda:

\begin{abstract}
A diretora do Peru escreveu: "não temos dinheiro mas vamos fazer mais um PROFIC". O dela vai ser o $5^{\circ}$ sob meus cuidados. Então, temos de inovar na temática que inventar, e ela vem comigo porque sabe que eu estava na raiz do movimento por formação. Eu conduzi o $5^{\circ}$ PROFIC. Então, a ideia do PROFIC continua viva e continua sendo trabalhada. Não sei se mais alguém tem feito, não tenho esse registro. Mas o professor Viana foi chamado para um PROFIC extra na República Dominicana, fez outro sozinho no Peru. Tem essas histórias, individuais, que surgem por iniciativa próprias dos Centros.
\end{abstract}

O acadêmico afirmou, ainda, que as políticas do Ministério das Relações Exteriores, implementadas pela DPLP, no que se refere ao ensino e capacitação de professores de PLE, são momentâneas. Por exemplo, o PROFIC não foi institucionalizado, apesar da proposta feita pelo referido professor.

Em consonância com os comentários do acadêmico, Libâneo et al. (2012, p. 16) asseveram que existe um grande desafio que deve ser enfrentado no campo da institucionalização da formação por meio de uma política instalada que deve contemplar sua formação e sua valorização profissional, e suas condições de trabalho. Os autores afirmam, ainda, que pesquisadores têm apontado para a importância do investimento no desenvolvimento profissional, que envolve formação inicial e continuada, articulada a um processo de valorização profissional dos docentes.

Durante as entrevistas feitas nos três países visitados, perguntamos aos professores sobre as necessidades de formação que eles têm. Apresentamos, a seguir, uma sistematização 
das propostas de formação dos docentes de PLE dos centros que têm vínculo direto com o Itamaraty: CCBES e CCBN:

TABELA 11: Propostas de formação docente CCBES e CCBN

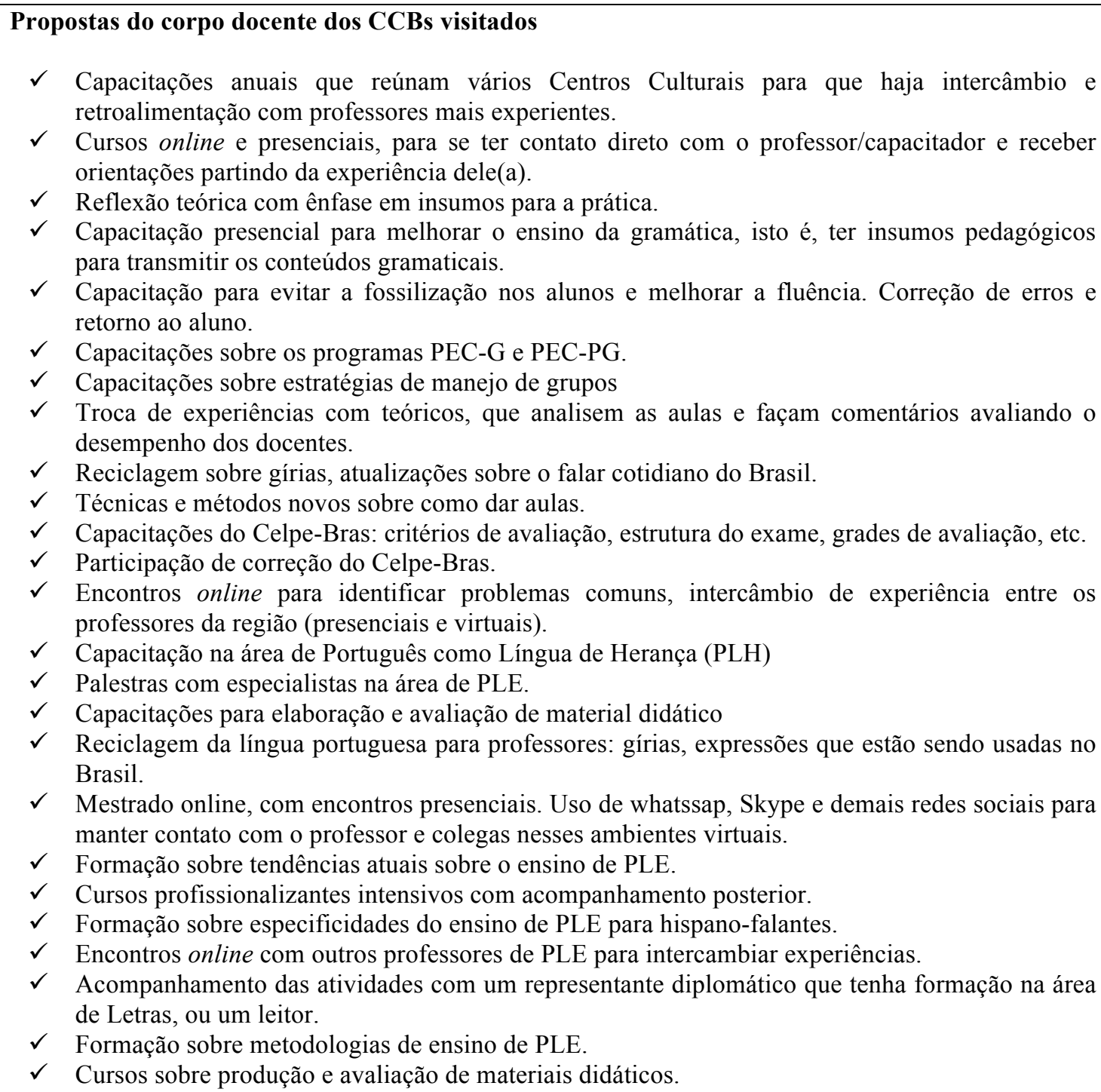

$\checkmark \quad$ Troca de experiências com teóricos, que analisem as aulas e façam comentários avaliando o desempenho dos docentes.

$\checkmark$ Reciclagem sobre gírias, atualizações sobre o falar cotidiano do Brasil.

$\checkmark$ Técnicas e métodos novos sobre como dar aulas.

$\checkmark$ Capacitações do Celpe-Bras: critérios de avaliação, estrutura do exame, grades de avaliação, etc.

$\checkmark$ Participação de correção do Celpe-Bras.

$\checkmark$ Encontros online para identificar problemas comuns, intercâmbio de experiência entre os professores da região (presenciais e virtuais).

$\checkmark$ Capacitação na área de Português como Língua de Herança (PLH)

$\checkmark$ Palestras com especialistas na área de PLE.

$\checkmark$ Capacitações para elaboração e avaliação de material didático

$\checkmark$ Reciclagem da língua portuguesa para professores: gírias, expressões que estão sendo usadas no Brasil.

$\checkmark$ Mestrado online, com encontros presenciais. Uso de whatssap, Skype e demais redes sociais para manter contato com o professor e colegas nesses ambientes virtuais.

$\checkmark$ Formação sobre tendências atuais sobre o ensino de PLE.

$\checkmark$ Cursos profissionalizantes intensivos com acompanhamento posterior.

$\checkmark$ Formação sobre especificidades do ensino de PLE para hispano-falantes.

$\checkmark$ Encontros online com outros professores de PLE para intercambiar experiências.

$\checkmark$ Acompanhamento das atividades com um representante diplomático que tenha formação na área de Letras, ou um leitor.

$\checkmark$ Formação sobre metodologias de ensino de PLE.

$\checkmark$ Cursos sobre produção e avaliação de materiais didáticos.

Sistematização nossa partindo das entrevistas concedidas

Como observado nas entrevistas, nos questionários e nas recomendações dos professores que pertencem aos institutos vinculados ao governo brasileiro, visitados na pesquisa, observamos que os docentes pedem cursos teóricos; entretanto, conforme observado nos depoimentos, houve baixo aproveitamento da informação dada por parte dos professores. Encontramos, também, que a experiência dos docentes deu origem a teorias implícitas que tentam explicar a realidade que os circunda, ou seja, teorias do cotidiano, em palavras de 
Blatyta (2009, p. 68). Essa teoria não foi confrontada ainda com teorias mais articuladas e explícitas, e as crenças e fórmulas se perpetuam para dar solução às urgências do cotidiano.

Por outro lado, em se tratando da formação dos professores, um programa que, a nosso ver, apresenta-se promissor na área de capacitação de professores de PLE é o Idiomas sem Fronteiras (IsF), lançado pelo Ministério da Educação em 17 de novembro de 2014. O programa está vinculado ao Ciência Sem Fronteiras e voltado para alunos e professores de línguas que desejam elevar a proficiência em línguas estrangeiras como o alemão, espanhol, inglês, francês, italiano, japonês e mandarim ${ }^{36}$. A medida foi publicada no Diário Oficial da União na portaria $\mathrm{N}^{\circ} 973$, de 14 de novembro de $2014^{37}$, como mostramos a seguir (grifos nossos):

\begin{abstract}
Art. $1^{\circ}$ Fica instituído o Programa Idiomas sem Fronteiras com o objetivo de propiciar a formação e a capacitação em idiomas de estudantes, professores e corpo técnico-administrativo das Instituições de Educação Superior Públicas e Privadas - IES e de professores de idiomas da rede pública de educação básica, bem como a formação e a capacitação de estrangeiros em língua portuguesa.

$\S 1^{\circ}$ As ações empreendidas no âmbito do Programa Idiomas sem Fronteiras serão complementares às atividades do Programa Ciência sem Fronteiras e de outras políticas públicas de internacionalização da educação superior.

Art. 2o São objetivos do Programa Idiomas sem Fronteiras:

I - promover, por meio da capacitação em diferentes idiomas, a formação presencial e virtual de estudantes, professores e corpo técnico-administrativo das IES e de professores de idiomas da rede pública de educação básica, conferindo-lhes a oportunidade de novas experiências educacionais e profissionais voltadas para a qualidade, o empreendedorismo, a competitividade e a inovação [...]

VI - fortalecer o ensino de idiomas no país, incluindo o da língua portuguesa, e, no exterior, o da língua portuguesa e da cultura brasileira.
\end{abstract}

A partir da leitura da Portaria $n^{\circ}$ 973, estabelecemos comunicação via e-mail com Denis Francisco, responsável pela língua portuguesa no Programa Idiomas sem Fronteiras. O contato foi feito no dia 23.10.2015 e recebemos resposta no dia 28.10.2015. Nessa comunicação pessoal, comentou que está na fase de elaboração de um instrumento (questionário online) para fazer um mapeamento da situação dos Centros Culturais do mundo inteiro em relação ao ensino de PLE.

Far-se-á, segundo informou, uma plataforma virtual para enviar o questionário aos CCBs e afirmou que um dos objetivos de médio/longo prazo do Programa IsF-Português é capacitar os professores dessas instituições. Quando perguntamos se esse contato com os

\footnotetext{
${ }^{36}$ Mais informações disponíveis em: < http://oglobo.globo.com/sociedade/educacao/mec-lanca-idioma-semfronteiras-para-alunos-docentes-de-letras-estudarem-linguas-no-exterior-14578044 > Acesso em 10 de nov. 2015.

${ }^{37}$ Disponível em:

$<$ http://pesquisa.in.gov.br/imprensa/jsp/visualiza/index.jsp?data=17/11/2014\&jornal=1\&pagina=11\&totalArquiv os $=100>$ Acesso em 10 de nov. 2015.
} 
professores seria via Itamaraty, Denis Francisco respondeu que estão sempre em aproximação e diálogo com o MRE, e, acrescentou: "no que diz respeito especificamente ao mapeamento dos Centros Culturais, esse diálogo só tende a ser reforçado porque é de comum interesse que os Centros ampliem cada vez mais o ensino-aprendizagem da língua portuguesa e a divulgação da cultura brasileira".

A esse respeito, o Programa Idiomas sem Fronteiras é, em palavras de Almeida Filho, promissor e uma iniciativa que o deixa "esperançoso", segundo nos informou na entrevista. O acadêmico lamenta uma certa instabilidade nas decisões tratativas à difusão linguísticocultural no Itamaraty, devido a uma alta rotatividade dos diplomatas e alta rotatividade nos Centros, e à falta de pessoal especializado na área de ensino e aprendizagem de línguas, como vemos no seguinte depoimento:

\footnotetext{
O Itamaraty não é especialista em ensino de línguas, é especialista em aproximação de povos, de políticas diplomáticas. Então, o ensino de línguas não é parte deles mas foi por eles inventado. Eles têm uma história desde os anos 40. E isso é muito bom. Alguns diretores da DPLP eram mais sensíveis, eles procuravam as universidades. Eu colaboro com eles há mais de 30 anos.
}

Diante da bibliografia consultada, constatamos que, nas duas publicações da Rede em Revista (2014 e 2015), houve depoimentos e informações sobre a necessidade de formação docente. Ou seja, percebemos que há consciência da necessidade de formar os professores de português que estão mundo afora. Todavia, como evidenciamos, a frequência delas não satisfaz o corpo docente dos dois CCBs dos países visitados. Se tivesse tido mais frequência, o cenário seria diferente, conforme Almeida Filho analisou durante a entrevista:

\footnotetext{
Poderíamos estar ganhando muito terreno se tivéssemos continuado o programa de formação. Muda o diretor, o próximo não conhece, quer fazer outras coisas, porque entra alguém que diz: "eu quero levar pintura brasileira ao mundo todo, eu quero levar orquestras brasileiras ao mundo todo". São projetos maravilhosos, mas não têm o efeito que tem o ensino de línguas.
}

Outra iniciativa que despertou interesse no acadêmico foi a tentativa de trabalho em conjunto do Itamaraty, do Ministério da Educação e do Ministério da Cultura, chamado de Acordo Tripartite, entre as pastas: "eles se reuniram para conversar para ver se existia a possibilidade de criar alguma coisa. Eu fiquei muito animado, mas isso terminou sem acordo nenhum". Os argumentos de Almeida Filho têm relação com os do diplomata Lott (2009) que reconhece que, embora haja uma política atual do governo brasileiro para a promoção internacional do português, vê-se uma falta de clareza e persistência nas ações ministeriais do 
Ministério da Educação, do Itamaraty e do Ministério da Cultura (MinC), dando a impressão de possível concorrência. Contudo, a nosso ver, o Programa IsF é uma tentativa forte, instalada e bem estruturada que poderá aproximar as ações ministeriais em prol do ensino de português no exterior.

No que tange aos professores, como já exposto, deve-se pensar em formalizar uma política de capacitação e acompanhamento constantes, como o PROFIC, atendendo às demandas que eles expressam e fomentando a prática reflexiva por meio do confronto teórico e despertar o desejo de mudança, e acender no corpo docente a chama da consciência da função que realmente possuem: ser diplomatas culturais e profissionais que devem refletir a sua prática, a fim de se reconhecerem como agentes que possuem uma riqueza que, se for bem investida, terá ação duradoura: semear uma língua que pode(ria) ser inculcada nas próximas gerações, criar e fortalecer laços diplomáticos entre os países e contribuir para o crescimento e reconhecimento do Brasil como destino de estudos, profissionalização e investimentos financeiros.

Dessa forma, o papel do professor vai muito além de ser um falante competente da língua estrangeira, como afirmam Moutinho e Almeida Filho (2015, p. 86), uma vez que deve levar os alunos a níveis aceitáveis de proficiência, mas também deve motivar, elucidar e explicar os processos evolutivos da cultura, da história e da economia de um país (ou países), fazendo com que os alunos atuem no espaço chamado língua estrangeira e participem do seu próprio processo de aprendizagem.

O professor, salientam os autores, deve ser um facilitador capaz de promover a cultura e a língua, sendo como qualquer bom diplomata, um profissional na língua e na cultura da língua que ensina e a do aluno, para promover relações harmônicas entre ele(a) e seus estudantes, criando um ambiente mútuo de conhecimento, aceitação, compreensão e negociação de ambas as línguas/culturas.

Assim sendo, retomando as duas forças abrangidas nesta dissertação, observamos que a história reforça 1) a presença massiva da gramática: nos países visitados, evidenciamos a primazia do ensino estrutural, que lentamente vai caminhando a um ensino comunicativizado, munido de tentativas, crenças, tradições. Evidenciamos um esforço importante, vibrante de formação oficial que foi pouco aproveitado pelos docentes, pois a força da tradição de ensino, de pessoas sem formação específica na área do Ensino e Aprendizagem de Línguas Estrangeiras permeou mais profundamente no exercício profissional dos professores em serviço. Observamos, também, uma riqueza no toque pessoal para acolher e incentivar alunos que querem conhecer o Brasil, sua cultura e seu sistema educacional. O corpo docente é 
carismático, alegre e o fato de a maioria ser de nacionalidade brasileira chama a atenção dos discentes centro-americanos.

Por outro lado, as políticas apontam para um papel crucial do Estado que crie estruturas que devem ser bem cuidadas, repensadas e mantidas. Assim, poder-se-ia evitar que programas de formação continuada deixem de ser episódicos e tenham uma política de Estado estável. Observamos, também, que é relevante refletir sobre o papel potencial que políticas institucionais possuem (universidades como a UES, que pretende adicionar o Português ao currículo, instituições como a FCDEB, que fomentou a maior difusão do PLE na Costa Rica, e hoje em dia é a maior instituição, com o maior número de alunos, e maior demanda dos países visitados para a presente dissertação. Consideramos esse ponto relevante para futuras pesquisas na área de políticas de difusão/promoção de línguas estrangeiras.

Em suma, com o propósito de tecer considerações finais que sejam consistentes após a pesquisa que desenvolvemos, retomaremos os objetivos que nortearam a nossa investigação. Assim sendo, apresentamos as perguntas de investigação e os objetivos expostos no primeiro capítulo com a argumentação advinda da análise e discussão de dados colhidos. Em seguida, na subseção 5.2, descrevemos contribuições que acreditamos que a presente investigação pode agregar à área de Linguística Aplicada no contexto brasileiro, para por fim, nas subseções seguintes - 5.3 e 5.4 respectivamente - discorrer sobre limitações evidenciadas na consecução da presente dissertação, bem como sugestões de pesquisas futuras desdobradas ou motivadas pelo recorte aqui empreendido.

\subsection{Objetivos específicos e perguntas de pesquisa}

Conhecer as ações institucionalizadas do governo brasileiro que têm relação com a promoção linguístico-cultural no exterior, mais especificamente em El Salvador, Nicarágua e Costa Rica.

Apresentamos um percurso cronológico das ações que o governo brasileiro manteve com três instituições: CCBES, CCBN e FCDEB, localizadas em El Salvador, Nicarágua e Costa Rica, respectivamente.

Somado ao anterior, estão os programas de Estudante Convênio de Graduação e PósGraduação (PEC-G e PEC-PG, respectivamente). Os centros de ensino visitados têm o labor, além das aulas de PLE, de aplicar o Celpe-Bras, de oferecer informações sobre os programas de Estudante Convênio, receber a documentação e enviar ao Brasil. Vimos, também, que só a Nicarágua teve uma leitora no ano 2008. 
Evidenciou-se que as capacitações para professores dos centros visitados foram produto, em parte, porque havia diplomatas com mais sensibilidade na questão da formação docente.

Assim, vimos que El Salvador teve 3 capacitações oficiais (PROFIC) e a Nicarágua 2 (PROFIC). A Costa Rica, pelo fato de ser uma fundação privada sem fins lucrativos, planejou a sua própria metodologia de formação docente. Esse número deu origem a uma avaliação dos professores dos cursos recebidos, e fechamos com sugestões que poderiam ser levadas em consideração na hora de planejar capacitações para formar professores de PLE no exterior.

Algumas contribuições que acreditamos que a presente investigação pode agregar à área de Linguística Aplicada no contexto brasileiro são, dentre outras, o conhecimento do contexto histórico e atual do ensino de PLE em três países da América Central. Levando em consideração que a maior quantidade de CCBs estão neste continente, as informações aqui relatadas poderiam ser do interesse do Itamaraty e dos programas de pesquisa da área do ensino e aprendizagem de línguas estrangeiras.

Por outro lado, segundo informações do coordenador do programa Português sem Fronteiras, do Idioma sem Fronteiras, está sendo criada uma base de dados sobre o contexto atual do ensino de PLE no exterior, e pretende-se planejar um curso de formação de professores de português como língua estrangeira no exterior via Itamaraty. Assim, oferecemos os insumos do feedback dos professores dos países visitados, assim como sugestões para a criação do processo de formação do corpo docente.

Uma limitação que encontramos foi a falta de tempo para permanecer mais em campo e poder compreender mais a história do ensino de português nesses países. Foi-nos sugerido fazer uma pesquisa via internet, enviando questionários online para os professores e diretores dos centros visitados para obtermos a informação apresentada na presente dissertação. Porém, amparados numa visão malinowskiana, quisemos ir a campo, pois as pesquisas in loco dão riqueza à análise e à compreensão do fenômeno social estudado. Assim, fomos à América Central com fundos próprios, o que limitou a permanência em campo.

Consideramos que a presente pesquisa pode ser desdobrada e enriquecida para fortalecer a construção de conhecimento no campo da Linguística Aplicada. Achamos, veementemente, que a pesquisa história deu insumos valiosos para a compreensão do contexto de ensino de PLE mundo afora. Assim, uma pesquisa desta natureza pode ser reproduzida em outros contextos, quiçá mais favoráveis, de ensino da língua portuguesa falada no Brasil. Dessa forma, pastas como o Itamaraty ou o Ministério da Educação 
poderiam empreender pesquisas que retratem os processos de difusão linguístico-cultural do Brasil ao longo dos anos.

A retroalimentação presente nesta pesquisa, consideramos, é um elemento básico e fundamental na hora de pensar em cursos de formação de professores em serviço. $\mathrm{Na}$ apresentação e discussão de registros colhidos, vimos que os docentes têm necessidades específicas em se tratando de formação profissional. Um insumo sistematizado de feedback e sugestões poderia ser de grande valor para as instituições governamentais que estão planejando cursos de formação de professores de PLE dentro ou fora do Brasil. Desse modo, um princípio elementar da área da Linguística Aplicada começaria a se evidenciar com a informação aqui apresentada: conhecer o grupo antes de planejar um curso de formação.

Nessa formação, acreditamos, deve haver teoria relevante e suficiente, em linguagem compreensível, para que os docentes em exercício possam refletir as suas práticas e as dos demais, para que haja neles uma construção paulatina da consciência de que eles são mais do que transmissores de uma língua, mas diplomatas culturais do Brasil, representantes da diversa e rica cultura deste país.

Outra pesquisa que poderia ser gerada a partir desta dissertação é na construção de uma política específica, oficial, que não privilegie a difusão da cultura brasileira, senão que contemple o ensino da língua e a capacitação constante do corpo docente. Como foi exposto por Almeida Filho, há mais ganho na hora de capacitar professores do que promover uma orquestra no exterior. $\mathrm{O}$ ensino de português tem impacto duradouro, e faz-se diplomacia dentro de uma sala de aula. 


\section{REFERÊNCIAS}

ALENCAR, E. A importância da História do Brasil para Compreender a Trajetória do Ensino de Línguas no País, Revista HELB. Ano 3, No $3-1 / 2009$. Disponível em: http://www.helb.org.br/index.php?option=com_content\&view=article\&id=112:a-importanciada-historia-do-brasil-para-compreender-a-trajetoria-do-ensino-de-linguas-nopais\&catid=1082:ano-3-no-03-12009\&Itemid=10\#1 Acesso em 28 de julho de 2014.

ALEXIS, K. Os bastidores do processo de ensino de português em contextos multilingües: o caso de Côte d'Ivoire. Brasília: Departamento de Línguas Estrangeiras e Tradução, Universidade de Brasília, 2008. Dissertação de mestrado.

ALMEIDA FILHO, J.C.P \& LOMBELLO, Leonor (Orgs.) Identidade e Caminhos no Ensino de Português para Estrangeiros. Pontes: Editora da Universidade Estadual de Campinas, 1992, Campinas, SP.

ALMEIDA FILHO, J.C.P. Fundamentos de Abordagem e Formação no Ensino de PLE e de Outras Línguas. Campinas, SP. Ponte Editores, 2011.

Auto-análises de abordagem e de competências na formação continuada intensiva de professores de línguas. In: SILVA, K. A. da. (Org.) Ensinar e Aprender Línguas na Contemporaneidade: Linhas e Entrelinhas. Campinas, Pontes Editores, 2010.

Universidade de Brasília, s.d; s.e.

Fundamentos do Estudo da História do Ensino de uma Língua.

Ontem e Hoje no Ensino de Línguas no Brasil. In: STEVENS, M. T. \& CUNHA, M. J. (Orgs.) Caminhos e Colheita: Ensino e Pesquisa na Área de Inglês no Brasil. Brasília: Editora UnB, 2003.

2012 .

. Quatro Estações no Ensino de Línguas. Campinas, SP: Pontes Editores.

. Sinalizadores de um Código de Ética para o Ensino de Línguas, portal SALA, Ano de Publicação 2014. Disponível em: $<$ http://www.sala.org.br/index.php/estante/colunas/formacao-de-professores/992sinalizadores-para-uma-etica-no-ensino-de-linguas> Acesso em 24 nov., 2014.

- Ensino de português língua estrangeira/EPLE: a emergência de uma especialidade no Brasil. In: LOBO, T.; CARNEIRO, Z.; SOLEDADE, J.; ALMEIDA, A.; RIBEIRO, S. (Orgs). ROSAE: Linguística Histórica, História das Línguas e Outras Histórias. Salvador: EDUFBA, 2012).

ANTHONY, E. M. Approach, Method and Technique. In: English Language Teaching, vol. 17, 1963.

ARIÈS, P. O tempo da história. São Paulo: Editora UNESP, 2013. 
ARNOUX, E. Política linguística: los contextos de la disciplina. In: Políticas Linguísticas para América Latina. Actas del Congreso Internacional [7997]. Buenos Aires: Universidad de Buenos Aires 1 Facultad de Filosofía y Letras, Instituto de Lingüística, pp. 13-24, 1999.

BAGNO, M.; CARVALHO, O. O potencial do português brasileiro como língua Internacional. Revista Interdisciplinar • Ano X, v.22, jan./jun. 2015.

BATISTA, M. C. Pontos e entrepontos: apontamentos cronológicos para uma narrativa histórica do ensino de língua portuguesa em ambiente escolar no Brasil. Brasília: Departamento de Línguas Estrangeiras e Tradução, Universidade de Brasília, 2014, Dissertação de mestrado.

BLATYTA, D. F. Mudança de hábitus e teorias implícitas: uma relação dialógica no processo de educação continuada de professores. In: ALMEIDA FILHO, J.C.P de (Org.) $\mathbf{O}$ professor de língua estrangeira em formação. Campinas: Pontes Editores, 2009.

BARBOSA, E. Subsídios para um Código de Ética na Profissão de Ensinar Línguas. Brasília: Departamento de Línguas Estrangeiras e Tradução, Universidade de Brasília, 2014, Dissertação de mestrado.

BARÇANTE, M. Configuração de competências de um professor de língua estrangeira (Inglês): implicações para a formação em serviço. Instituto de Estudos da Linguagem, Universidade Estadual de Campinas, 1999. Tese de doutorado.

BLOCH, M. Apologia da História ou o Ofício do Historiador. Tradução de André Telles. Rio de Janeiro: Jorge Zahar Editores, 2001.

BOHN, H. Os aspectos "políticos" de uma Política de Ensino de Línguas e Línguas Estrangeiras. Linguagem \& Ensino, Pelotas, v.3, n.1, p. 117-138, 2000.

BRASIL. Divisão de Promoção da Língua Portuguesa (DPLP). Relatório de Gestão 2008. Brasília, DF, 21 jan. 2009.

Ministério da Educação. Parecer relativo à criação do Sistema Unificado de Ensino da Língua Portuguesa para Estrangeiros. Brasília, 8 dejunho de 1989. Disponível em: <http://www.dominiopublico.gov.br/download/texto/cd004414.pdf $>$. Acesso em: 15 set. 2015 .

BUERgenthal, T. La Comisión de la Verdad para El Salvador. Revista Vanderbilt Journal of Transnational Law, n. 3, vol. 27. Outubro de 1994.

BURKE, E. Abertura: a nova história, seu passado e seu futuro. In: BURKE, E. (Org.) A escrita da história: novas perspectivas. São Paulo: Editora UNESP, 2011.

CASTRO ALVES, D. M. DE. Luso-Brasilidades nos 500 anos. Fortaleza: Casa de José de Alencar/Programa Editorial, 1999.

CASTRO, F. Itamaraty: Dois séculos de História. Vol 2 (1979-2008). Brasília: Funag, 2009. 
CHAGURI, J. \& AZEVEDO, M. Os aspectos políticos de uma política de ensino de Língua Estrangeira Moderna. In: CHAGURI, J \& TONELLI, J. (Orgs.) Perspectivas Educacionais e Ensino de Línguas. Londrina, Eduel, 2014.

DA SILVA, D. De Flor do Lácio a Língua Global. Jundaí: Paco Editorial: 2013.

DE CASTRO NETO, Francisco Tomé. História do Futuro: Diagnóstico e perspectivas de Políticas Públicas para o ensinoaprendizagem de PLE-PL2 no Brasil do século XXI. Brasília: Departamento de Línguas Estrangeiras e Tradução, Universidade de Brasília, 2013, 197 f. Dissertação de mestrado.

DENZIN, N \& LINCOLN, Y. S. Introdução: a disciplina e a prática da pesquisa qualitativa. In: DENZIN, N \& LINCOLN, Y. S. (Orgs.). O planejamento da pesquisa qualitativa: teorias e abordagens. Porto Alegre: Artmed, 2006.

DINIZ, L. Política Linguística do Estado Brasileiro na Contemporaneidade. A institucionalização de mecanismos de promoção da língua nacional no exterior. Campinas, 378 p., Tese (Doutorado em Linguística), IELUNICAMP, 2012.

FARGE, A. Lugares para a história. São Paulo: Autêntica, 2011.

FERREIRA, I. A. O processo ensino/aprendizagem de Português língua estrangeira no contexto do MERCOSUL: uma análise de abordagem e metodologia. Dissertação de mestrado, Universidade Estadual de Campinas, 1996.

FIORIN, J. L. Prefácio. In: MOITA LOPES, L. P. (Org.), Português no século XXIIdeologias Linguísticas. São Paulo: Parábola editorial, 2013.

FOUCAULT, Michel. Microfísica do poder. Rio de Janeiro: Graal, 1979.

FREITAS, M. Daquilo que Sabemos: pesquisa metateórica sobre abordagem de ensino de línguas. Brasília: Departamento de Línguas Estrangeiras e Tradução, Universidade de Brasília, 2013. Dissertação de mestrado.

GAY, P. O estilo na história: Gibbon, Ranke, Macaulay, Burckhardt. São Paulo: Companhia das Letras, 1990.

GLEZER, R. A história e o tempo presente. In: BRUNI, J.C; MENNA-BARRETO, L; MARQUES, N. (Orgs.) Decifrando o Tempo Presente. São Paulo: Editora UNESP, 2007.

GONZÁLEZ, L. A. El Salvador de 1970 a 1990: política, economía y sociedad. Revista Realidad, 67. Enero-febrero. UCA Editores, 1999.

GUIMARÃES, M. L. S. Entre as luzes e o romantismo: as tensões da escrita da história no Brasil oitocentista. In: GUIMARÃES, M. L. S. Estudos sobre a escrita da história. Rio de Janeiro: 7 Letras, 2006.

GUMBRECHT, H. Em 1926. Vivendo no Limite do Tempo. Rio de Janeiro, Editora Record: 1999. 
HALBWACHS, M. A memória coletiva. São Paulo: Vértice, 1990.

HANDLIN, O. A Verdade na História. Tradução de Luciana Silveira de Aragão e Frota \& Yvone Dias Avelino. Brasília: Ed. Universidade de Brasília, 1982.

HOBSBAWN, E. Era dos extremos: o breve século XX (1914 - 1991). São Paulo: Companhia das Letras, 1995.

HORNBERGER, N. Frameworks and models in Language Policy and Planning. In: RICENTO, T. (Org.) An introduction to Language Policy: Theory and Method. Oxford: Blackwell Publishing, 2006.

HOWATT, A.P.R. \& WIDDOWSON, H.C. A History of English Language Teaching. 2a Edição. Oxford, NY: Oxford University Press, 2004.

KÖVECSES, Z. Metaphor in Culture: universality and variation. Cambridge: Cambridge University Press, 2005.

LE GOFF, J. História e Memória. Campinas, SP: Editora da UNICAMP, 1994.

LIBÂNEO, J.; OLIVEIRA, J. F. de; TOSCHI, M. Educação escolar: políticas, estrutura e organização. São Paulo: Cortez Editora, 2012.

LIMA, D. M. \& BERTOLETTI, E. N. M. A produção científica acerca da história do ensino de língua portuguesa no Brasil. ( $\mathrm{s} / \mathrm{d})$. Disponível em: http://sbhe.org.br/novo/congressos/cbhe7/pdf/06-

$\% 20$ HISTORIA $\% 20$ DAS $\% 20$ CULTURAS\%20E\%20DISCIPLINAS\%20ESCOLARES/A $\% 2$ 0PRODUCAO $\% 20$ CIENTIFICA $\% 20$ ACERCA $\% 20$ DA $\% 20$ HISTORIA $\% 20 D O \% 20$ ENSIN O\%20DA\%20LINGUA\%20PORTUGUESA\%20NO\%20BRASIL.pdf Acesso em 28 de julho de 2014.

LIMA, M. A. D. S.; ALMEIDA, M. C. P. \& LIMA, C. A utilização da observação participante e da entrevista semiestruturada na pesquisa de enfermagem. Revista Gaúcha de Enfermagem, 20, 130-142. 1999.

LOTT, L. A política de promoção da língua portuguesa implementada pelo departamento cultural do itamaraty: realidade e desafios. In: III Encontro Nacional sobre Políticas de Língua(s) e Ensino. Brasília, ALAB, 2009.

LÜDKE, M.; ANDRÉ, M. E. D. A pesquisa em educação: abordagens qualitativas. São Paulo: EPU, 1986. p. 1-10.

LUFT, C.P. Língua e Liberdade. Porto Alegre: LP\&M, 1984.

MARTINS, J. B. Observação participante: uma abordagem metodológica para a psicologia escolar. Semina: Ciências Sociais/Humanas, 17, p. 266-273. 1996. 
MELlO BARBOSA, E. Subsídios para um Código de Ética na profissão de ensinar línguas. Brasília: Departamento de Letras e Tradução, Universidade de Brasília, 2014, 226 f. Dissertação de Mestrado.

MORITA, M. Diários dialogados na formação continua do professor. In: ALMEIDA FILHO, J. C. P. de. Português para Estrangeiros: Interface com o Espanhol. São Paulo: Pontes Editora, 2001.

MOURA FILHO, C. A. L. Reinventando a aula: por um contexto cooperativo para a aprendizagem de inglês como língua estrangeira. Brasília: Departamento de Linguística, Línguas Clássicas e Vernáculas, Universidade de Brasília, 2000. Dissertação de mestrado.

.Pelo inglês afora: carreira profissional e autonomia na aprendizagem de inglês como língua estrangeira. Belo Horizonte. Faculdade de Letras, Universidade Federal de Minas Gerais, 2005. Tese de Doutorado em Linguística Aplicada.

MOUTINHO, R; ALMEIDA FILHO, J. C. P. de: Diplomacia Cultural no Ensino de Línguas Estrangeiras: Algumas Evidências Apontadas por Professores de PLE. Revista Platô, vol. 3, n 5, p. 10-20, 2014.

MOUTINHO, R; ALMEIDA FILHO, J. C. P. de: The role of language teachers as cultural diplomats. Multicultural Education Review, vol. 7, n 1-2, p. 85-98, 2015. Disponível em: $<$ http://dx.doi.org/10.1080/2005615X.2015.1061920> Acesso em 8 de out. 2015.

NABUCO, E. Uma reflexão sobre a história em Nietzsche e Foucault: a história efetiva como contramemória. Revista Mnemosine Vol.3, no1, p. 66-79 (2007) . Disponível em http://www.mnemosine.com.br/ojs/index.php/mnemosine/article/viewFile/104/pdf_90 Acesso em $1 / 12 / 2014$.

NAKAGOME, P. A Formação continuada de professors de PLE no exterior. In: AMADO, R. DE SÁ; GIL, B. (Orgs.) Reflexões sobre o ensino de português para falantes de outras línguas. São Paulo: Editora Paulistana, 2012.

NIETZSCHE, F. Escritos sobre História. Ed. PUC Rio; São Paulo: Loyola, 2005.

OLIVEIRA, L. E. A instituição do ensino das línguas vivas no Brasil: o caso da língua inglesa (1809-1890). Tese (Doutorado em Educação) - Pontifícia Universidade Católica de São Paulo, 2006.

ORLANDI, E. Há palavras que mudam de sentido, outras... demoram mais. In: ORLANDI, E. (Org.). Política Linguística no Brasil. Campinas, SP: Pontes Editores, 2007.

PEREIRA, M. H. de F. A Máquina da Memória: o tempo presente entre a história e o jornalismo. Bauru, SP: EDUSC, 2009.

PEREIRA, M. H. de F.; MATA, S. da. Introdução: Transformações da experiência do tempo e pluralização do presente. In: VARELLA, F. (Org.) Tempo presente \& usos do passado Rio de Janeiro : Editora FGV, 2012. 
PERRENOUD, P. Dez novas competências para ensinar. Porto Alegre, Artmed Editora, 2000 .

PICANÇO, D. História, Memória e Ensino de Espanhol (1942-1990). Curitiba: UFPR, 2003.

PINSKY, C. \& DE LUCA, T. O Historiador e suas Fontes. São Paulo, SP: Editora Contexto, 2011.

PIRES, F. O ensino de português na Costa Rica: razões para seu aprendizado. Trabalho de Conclusão de Curso para a obtenção do grau em Licenciatura em Letras EspanholPortuguês. Universidade Federal do Rio Grande do Sul, 2013.

PLEITEZ, R. Por qué ocurrió una guerra en El Salvador y no en Honduras. Revista Realidad 45, mayo-junio. UCA Editores, 1995.

POMIAN, K. Tempo/Temporalidade. Tradução de Maria Bragança. Lisboa: Imprensa Nacional/ Casa da Moeda, 1993. (Enciclopédia Einaudi; v. 29).

PRINS, G. História oral. In: BURKE, E. (Org.) A escrita da história: novas perspectivas. São Paulo: Editora UNESP, 2011.

PUNCH, M. Politics and ethics in qualitative research. In: DENZIN, N \& LINCOLN, Y. S. (Eds.) Handbook of qualitative research. London: Sage, 1994.

REMOND, R. Por uma História Política. Rio de Janeiro: Fundação Getúlio Vargas, 1993.

RIBEIRO, E. Diplomacia cultural: seu papel na política externa brasileira. Brasília:

Fundação Alexandre de Gusmão, 1989.

RICENTO, T. Language Policy: Theory and Practice, An Introduction. In: RICENTO, T. (Org.) An introduction to Language Policy: Theory and Method. Oxford: Blackwell Publishing, 2006.

RICHARDS, J. C \& RODGERS, T .S. Method: approach, design \& procedure. In TESOL Quaterly, vol. 16/02, 1982.

RICHARDSON, L. Writing: a method of inquiry. In: DENZIN, N \& LINCOLN, Y. S. (Eds.). Handbook of qualitative research. London: Sage, 1994.

ROSA, M. \& ARNOLDI, M. A entrevista na pesquisa qualitativa. Belo Horizonte: Autêntica, 2006.

RUBÉN, R. El problema agrario en El Salvador: Notas sobre una Economía Agraria Polarizada. Cuadernos de Investigación de CENITEC, (abril). San Salvador: Druk, 1991.

RÜSEN, J. Reconstrução do passado. Brasília: Editora Universidade de Brasília, 2010. 
SANTOS, André. A análise de abordagem e a formação do professor de línguas estrangeiras: uma alternativa à prática reflexiva. Círculo Fluminense de Estudos Filológicos e Linguísticos. Cadernos do CNLF, Vol. XII, N5. 2008.

SCHMIDT, R. Sr. Political Theory and Language Policy. In: RICENTO, T. (Org.) An introduction to Language Policy: Theory and Method. Oxford: Blackwell Publishing, 2006.

SCHÜKLENK, U. Ética na pesquisa: experiência de treinamento em países sul-africanos. In: DINIZ, D; GUILHEM, D. \& SCHÜKLENK, U. (Eds.) Brasília: Editora da UnB, 2005.

SCHWANDT, T. Três posturas epistemológicas para a investigação qualitativa: interpretativismo, hermenêutica e construcionismo social. In DENZIN, N. K. , LINCOLN, Y. S. O planejamento da pesquisa qualitativa: teorias e abordagens. Porto Alegre, Bookman e Artmed, 2006.

SELIGER, H. W. \& SHOHAMY, E. Second language research methods. Oxford University Press, 1995.

SILVA, B. A língua portuguesa na cultura mundial. São Paulo: Fundação Getúlio Vargas, 1990.

SIMÕES, A. R. M.; CARVALHO, A; WIEDEMANN, L (orgs). Português para Falantes de Espanhol. Campinas: Pontes, 2004.

STAKE, R. E. Case Studies. In: DENZIN, N. K.; LINCOLN, Y. S. (Eds.). Handbook of qualitative research. London: Sage, 1994.

TING,Y.R. Foreign language learning in China: Problems and Perspectives. In: Canadian and International Education, v. 16, n $1,1987$.

VESENTINI, C. A teia do Fato: Uma proposta sobre o estudo da memória histórica. São Paulo: Editora HUCITEC, 1997.

VEYNE. P. Como se escreve a história; Foucault revoluciona a história. Brasília: Editora Universidade de Brasília, 2014.

VIANA, N. Planejamento de Cursos de Línguas-Pressupostos e Percurso. In: ALMEIDA FILHO, J. C. P de. (Org.) Parâmetros Atuais para o Ensino de Português Língua Estrangeira. Campinas, SP: Pontes, 1997.

VIDOTTI, J. Políticas linguísticas para o ensino de língua estrangeira no Brasil do século XIX, com ênfase na língua inglesa. 2012. Tese (Doutorado em Estudos Linguísticos e Literários em Inglês). Universidade de São Paulo.

VIDOTTI, J. Política de Língua Estrangeira. O século XIX no Brasil. Novas Edições Acadêmicas: Berlim, 2013.

WHITE, A. EI Salvador. San Salvador: UCA Editores, 1983. 
APÊNDICES

\section{APÊNDICE A: TERMO DE CONSENTIMENTO E LIVRE ESCLARECIDO}

$\mathrm{Eu}$, , declaro estar ciente de minha participação na pesquisa intitulada: Cursos e (per)cursos: aspectos históricos e políticos do ensino de PLE na América Central, desenvolvida por Fidel Armando Cañas Chávez, Mestrando em Linguística Aplicada na Universidade de Brasília.

Estou igualmente ciente de que as análises dos registros utilizados nesta Pesquisa estarão à minha disposição e que me é dada a liberdade de retirar meu consentimento em relação à minha participação em qualquer fase do trabalho.

Sei também que tenho direito a quaisquer esclarecimentos que julgue necessário no que se refere à minha participação neste estudo, que tenho garantido o sigilo que assegura a privacidade quanto aos dados confidenciais envolvidos na pesquisa e que meu nome será divulgado só se eu o autorizar.

Declaro ter ciência de que os instrumentos possivelmente utilizados para a coleta de dados nesta pesquisa consistem em entrevistas que serão gravadas, como também diários de campo para a realização de observações em sala de aula, coleta de materiais didáticos, etc., sendo que tais dados poderão ser utilizados para fins científicos, publicações e participações em eventos científicos, no limite da ética e do proceder científico íntegro e idôneo.

Declaro, também, estar ciente de que a participação neste projeto não me oferecerá desconforto e que minha participação é total e completamente isenta de qualquer ônus financeiro. Estou igualmente ciente de que serei informado (a), assim como os demais participantes desta pesquisa, sobre os resultados deste estudo, assim que ele tiver sido devidamente concluído.

Nome:

Assinatura:

RG:

Local e Data: Tel: 


\section{APÊNDICE B: ROTEIRO INICIAL DE PERGUNTAS DE PESQUISA}

\section{Roteiro básico de perguntas}

1. Nome completo, idade, tempo de trabalho como professor de PLE, qual é a sua formação?

2. Tipo de contratação?

3. Como foi que você veio a este país, por favor, dê datas, eventos, lembranças, o que você lembra do começo.

4. Como você vê a situação atual do ensino de PLE? Há demanda, há interesse, como é visto o português neste país, por que as pessoas querem aprender português?

5. Como avalia a participação dos candidatos locais nos programas PEC-G e PEC-PG.

6. Que tipo de convênios você conhece da instituição e outras instituições?

\section{Sobre o trabalho desempenhado no Centro}

Quais foram as capacitações das quais você já participou?

Como você avalia essas capacitações?

Você acha que é necessário que haja capacitações dos professores em serviço?

O que poderia ser feito?

Vocês produzem material didático?

Quais os critérios de elaboração?

PERGUNTA FINAL: O que é, para você, significa ser professor(a) de PLE neste país? 
ANEXO C: LINHA DO TEMPO DE FATOS APRESENTADOS NA DISSERTAÇÃO

1938 Transformação do Serviço de Cooperação de Cooperação Intelectual -instituído no Itamaraty pela portaria de 8 de junho de 1937 durante a gestão Pimentel Brandão- na Divisão de Cooperação Intelectual do Departamento Diplomático e Consular através do decreto-lei n 791 de 14 de outubro desse ano, na gestão do ministro Oswaldo Aranha.

1940 Fundação da primeira instituição no exterior para a difusão da cultura brasileira: o Instituto Cultural Uruguaio-Brasileiro, em Montevidéu.

1956 Convênio de relações diplomático-culturais Brasil-Nicarágua

1964 Convênio de relações diplomático-culturais Brasil-Costa Rica

1968 Convênio de relações diplomático-culturais Brasil-El Salvador

1971 Criação da Fundação de Cultura, Difusão e Estudos Brasileiros da Costa Rica

1981 Criação do Centro Cultural Brasil-Nicarágua (antigo Centro de Estudos Brasileiros)

Criação do Centro Cultural Brasil-El Salvador (antigo Centro de Estudos Brasileiros)

1989 Iniciativas no sentido de melhor orientar a atuação da RBEx datam, pelo menos, do fim da década dos anos 80 no sentido de capacitação docente.

|| Anos A política de promoção da língua portuguesa baseava-se, apenas, nos Centros de Estudos 90 Brasileiros (CEBs). Os governos de Fernando Collor, Itamar Franco e Fernando Henrique $\|$ reduziam investimentos destinados ao Itamaraty e iniciaram a privatização de alguns Centros de Estudos Brasileiros.

Fim da guerra civil em El Salvador

- Privatização da Fundação de Cultura, Difusão e Estudos Brasileiros da Costa Rica

- Seminário organizado pela Divisão de Instituições de Ensino e Programas Especiais do Ministério das Relações Exteriores para os professores e diretores dos CEBs: Costa Rica, México, Panamá, El Salvador, Venezuela e Nicarágua

- Criação do Celpe-Bras por meio da portaria do Ministério da Educação $\mathrm{n}^{\circ}$ $1.787 / 1994$.

Retomadas de cursos de capacitação feito na Universidade de Brasília (UnB) coordenado pela DPLP.

2008 Patrícia Nakagome (primeira e única leitora da Nicarágua) chega ao CCBN 


\section{ANEXO A: A GRANDE OPERAÇÃO GLOBAL DE ENSINO DE LÍNGUAS (ALMEIDA} FILHO, 1993)

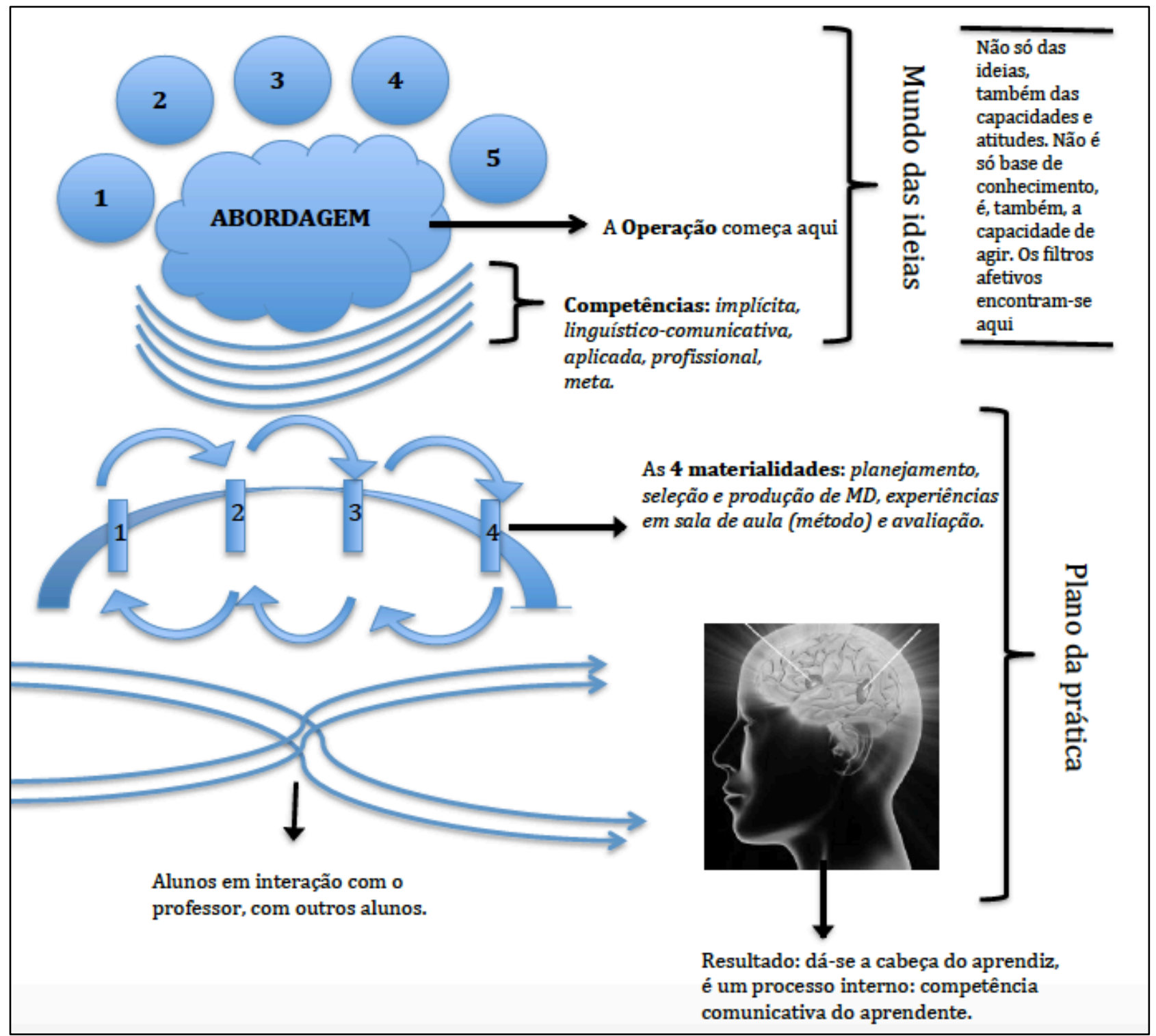

Esquema nosso, baseados na teoria da OGEL. Os números 1-5 representam as forças que condicionam a abordagem e todo o processo de ensino e aprendizagem de línguas: História, Teoria, Tradição, Código de Ética e Políticas de Ensino. 

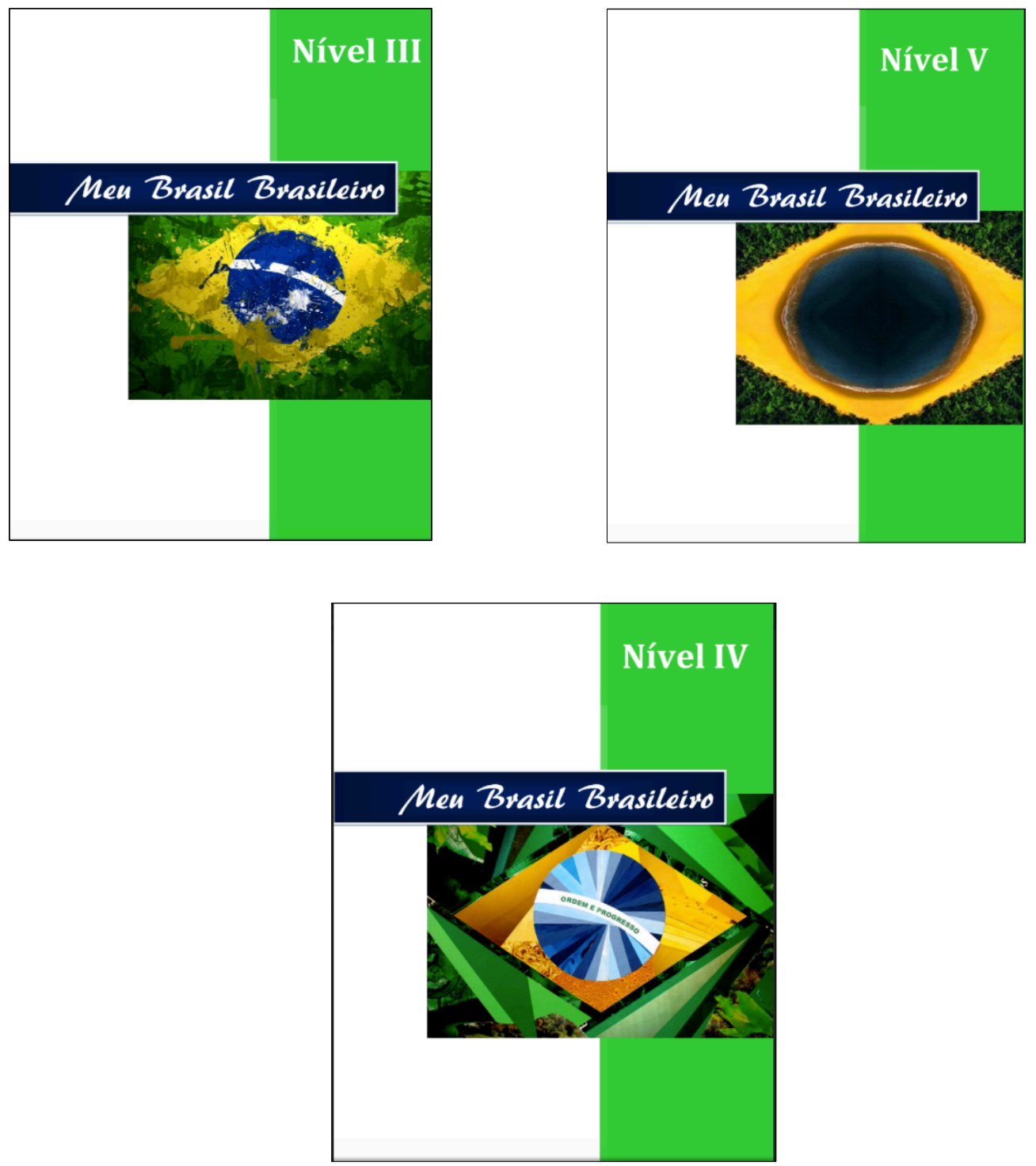

A coleção de 7 livros foi elaborada pela equipe de professores e começou a ser usada desde o ano 2011. Segundo foi informado, o material passa por revisão constante e o principal avaliador é o aluno. 


\title{
ANEXO C: MODELO DE EDITAL PARA CONTRATAÇÃO DE PROFESSOR DO CCBES
}

EDITAL

\author{
Embaixada do Brasil em São Salvador
}

A Embaixada do Brasil em San Salvador, no uso das atribuições que lhe foram conferidas, torna público que será realizado concurso para preenchimento de uma vaga de Professor(a) de Português, com carga horária de 40 horas semanais, para o Centro Cultural Brasil Cultural Brasil - El Salvador (CCBES).

1. DAS DISPOSIÇÕES PRELIMINARES

1.1. O concurso será regido por este Edital.

1.2. O processo seletivo será realizado no Centro Cultural Brasil Cultural Brasil - El Salvador (CCBES) e compreenderá as seguintes fases eliminatórias:

FASE I: Prova de títulos;

FASE II: Prova escrita de Língua Portuguesa;

FASE III: Entrevista com os candidatos aprovados nas 2 fases anteriores.

2. DOS REQUISITOS BÁSICOS PARA A INSCRIÇÃO

2. 1. PARA TODOS OS CANDIDATOS

2.1.1. Documento com foto;

2.1.2 Diploma ou certificado de conclusão de nível superior;

2.1.3. Domínio escrito e falado das línguas portuguesa e espanhola;

2.1.5. Comprovante de domicílio;

2.1.6. Atestado de bons antecedentes;

2.1.7. Curriculum vitae.

2.2. PARA OS CANDIDATOS NÃO SALVADORENHOS

2.2.1. Comprovação de situação regular de residência e permissão legal para o exercício de atividade remunerada nos termos da legislação local.

2.3. PARA OS CANDIDATOS DE NACIONALIDADE BRASILEIRA

2.3.1. Comprovante de estar em dia com as obrigações eleitorais;

2.3.2. Para os candidatos de sexo masculino, comprovação de estar em dia com o serviço militar;

2.3.3. Declaração de próprio punho de que não é servidor público brasileiro, ativo ou inativo.

3. DA INSCRIÇÃO PARA O CONCURSO

3.1. Período: de 29 de junho a 13 de julho, das 9 às $12 \mathrm{~h}$.

3.2. Local da Inscrição: Sede do Centro Cultural Brasil - El Salvador (CCBES), Boulevard Sérgio Vieira de Mello ${ }^{\circ} 132$ Colônia San Benito, San Salvador.

4. DO CONCURSO

4.1. Serão considerados aprovados na primeira fase do concurso (análise curricular) os candidatos que demonstrarem aptidão para exercer com competência a função de professor(a) do Centro Cultural Brasil - El Salvador (CCBES).

4.2. A relação dos aprovados em cada uma das fases será afixada na recepção da Embaixada do Brasil em São Salvador, assim como no sítio eletrônico do Centro Cultural Brasil - El Salvador (CCBES), em datas indicadas abaixo.

4.3. O resultado da primeira fase (prova de títulos) será divulgado em 15 de julho de 2015 .

4.4. Os candidatos aprovados na primeira fase serão convocados para a segunda fase, a qual consistirá em prova escrita de Português, a ser realizada no dia 17 de julho de 2015, das 9 ás 11h, no Centro Cultural Brasil - El Salvador (CCBES).

4.5. O resultado da segunda fase será divulgado no dia 21 de julho de 2015. 
4.6. Os candidatos aprovados na segunda fase serão convocados para a terceira fase, a realizar-se no dia 23 e 24 de julho de 2015, às 9 h.

5. DO RESULTADO FINAL

5.1. A classificação dos candidatos aprovados será determinada com base na média das notas obtidas nas fases I, II e III.

5.2. O resultado do concurso será divulgado no dia 28 de julho de 2015 na recepção e no sítio eletrônico e perfil de Facebook da Embaixada do Brasil em São Salvador e no Centro Cultural Brasil - El Salvador (CCBES).

6. DA VALIDADE DO CONCURSO

6.1. O resultado do concurso terá validade de 12 (doze) meses contados a partir da data de divulgação do seu resultado final.

6.2. À exceção do primeiro colocado, os demais candidatos aprovados serão incluídos em cadastro de reserva válido por um ano e contratados na medida em que as surjam vagas. 


\section{ANEXO D: CONVÊNIOS HISTÓRICOS BRASIL-EL SALVADOR; BRASIL- NICARÁGUA E BRASIL-COSTA RICA}
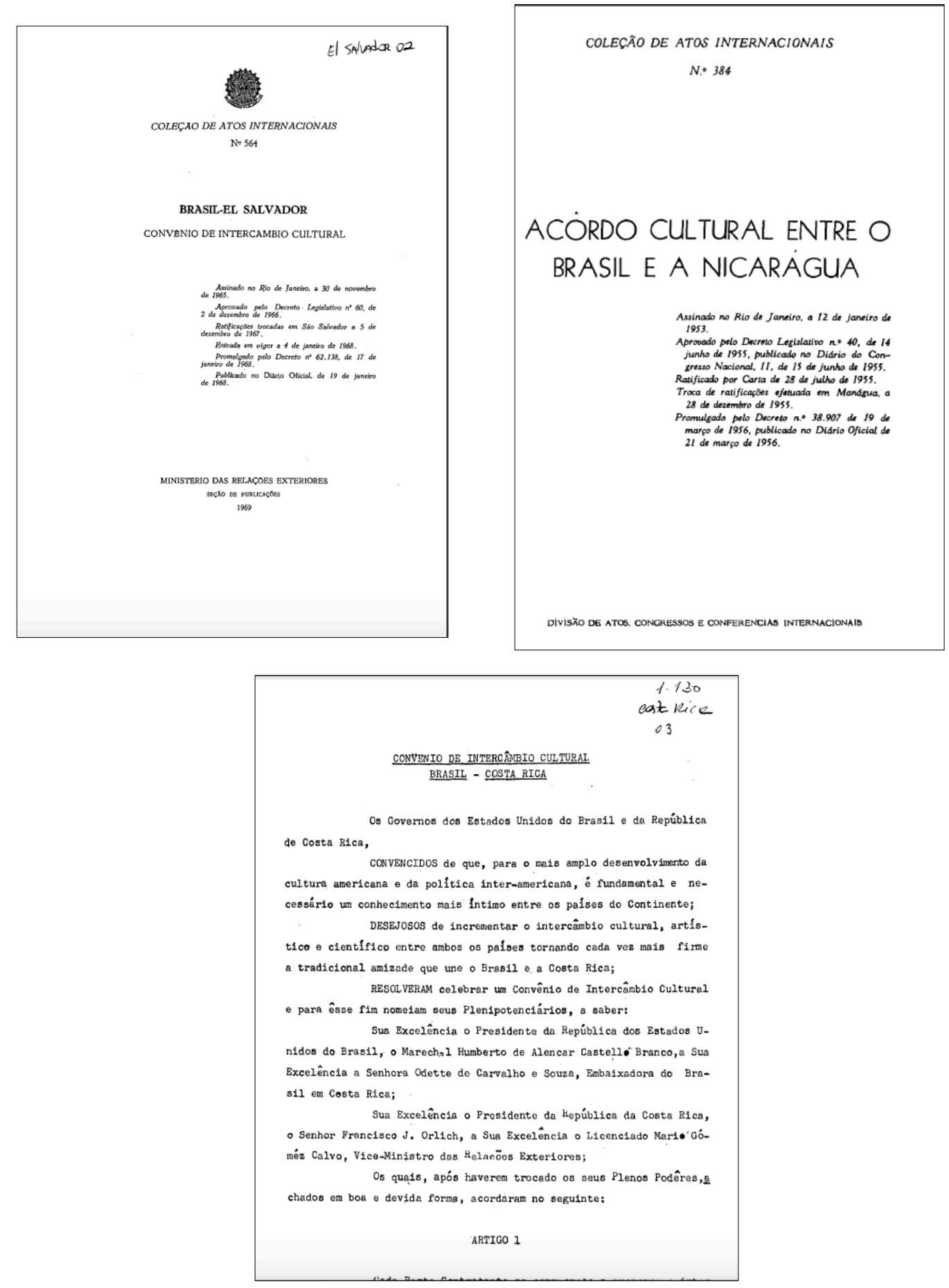

Acordos do Brasil com os países visitados. Assinado em 1965, com El Salvador; com a Costa Rica em 1964; e com a Nicarágua em 1953. 
ANEXO E: FOTOGRAFIAS DO CENTRO CULTURAL BRASIL-EL SALVADOR
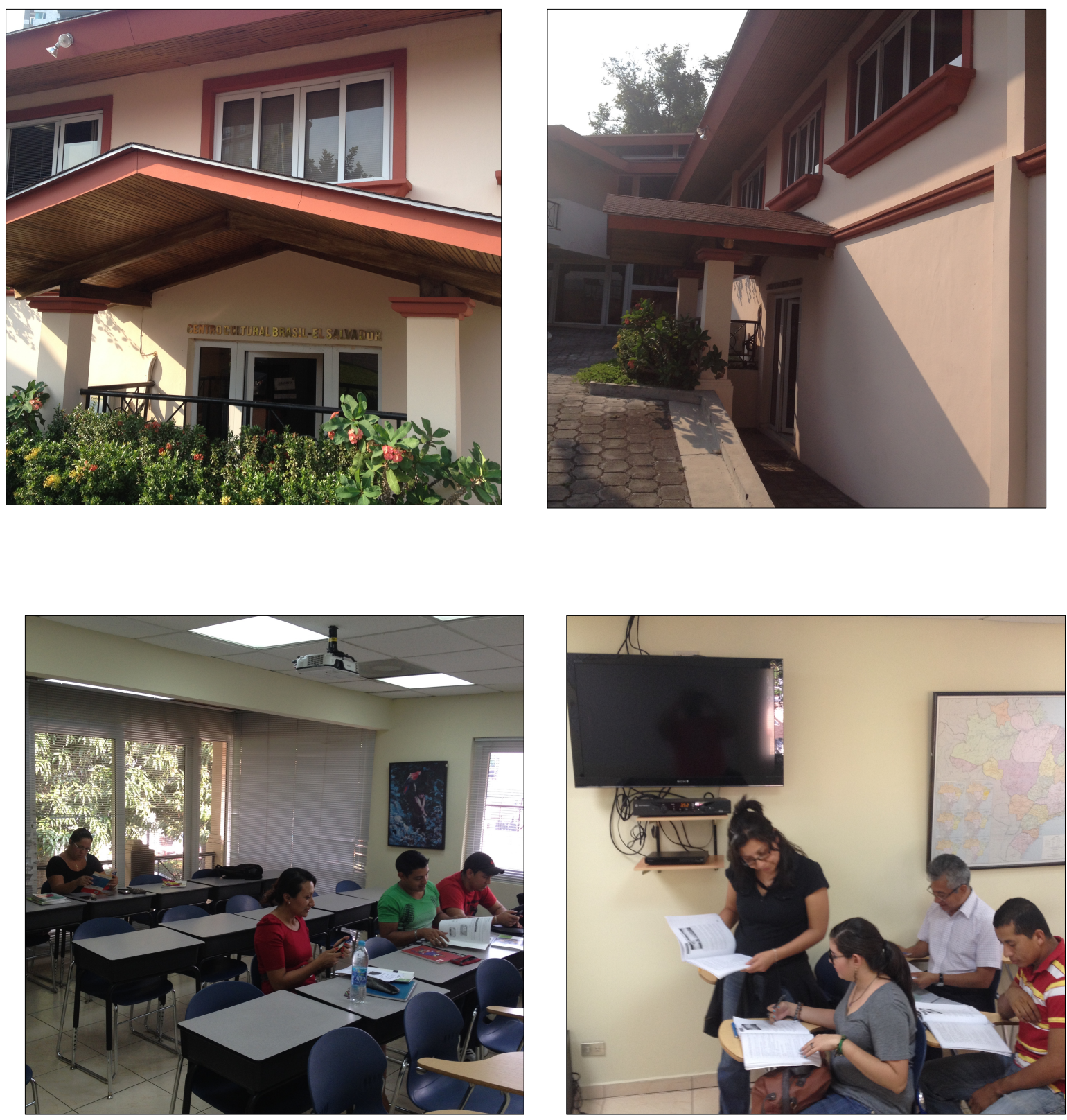

O centro cultural Brasil-El Salvador possui cinco salas de aulas, e está localizado na Zona Rosa, que é uma zona nobre da capital, San Salvador. Segundo foi informado, são aproximadamente 600 alunos por trimestre letivo. A estrutura do curso são de 7 trimestres e contam com a produção de material didático próprio.

Website: http://www.ccbes.org.sv/indexp.html

Facebook: https://www.facebook.com/centroculturalbrasilelsalvador

Endereço e contato: Boulevard Sérgio Vieira de Mello No. 132, Col. San Benito, San

Salvador. Fone de contato: (503) 2223-4031 e (503) 2245-3008. 
ANEXO F: FOTOGRAFIAS DO CENTRO CULTURAL BRASIL-NICARÁGUA
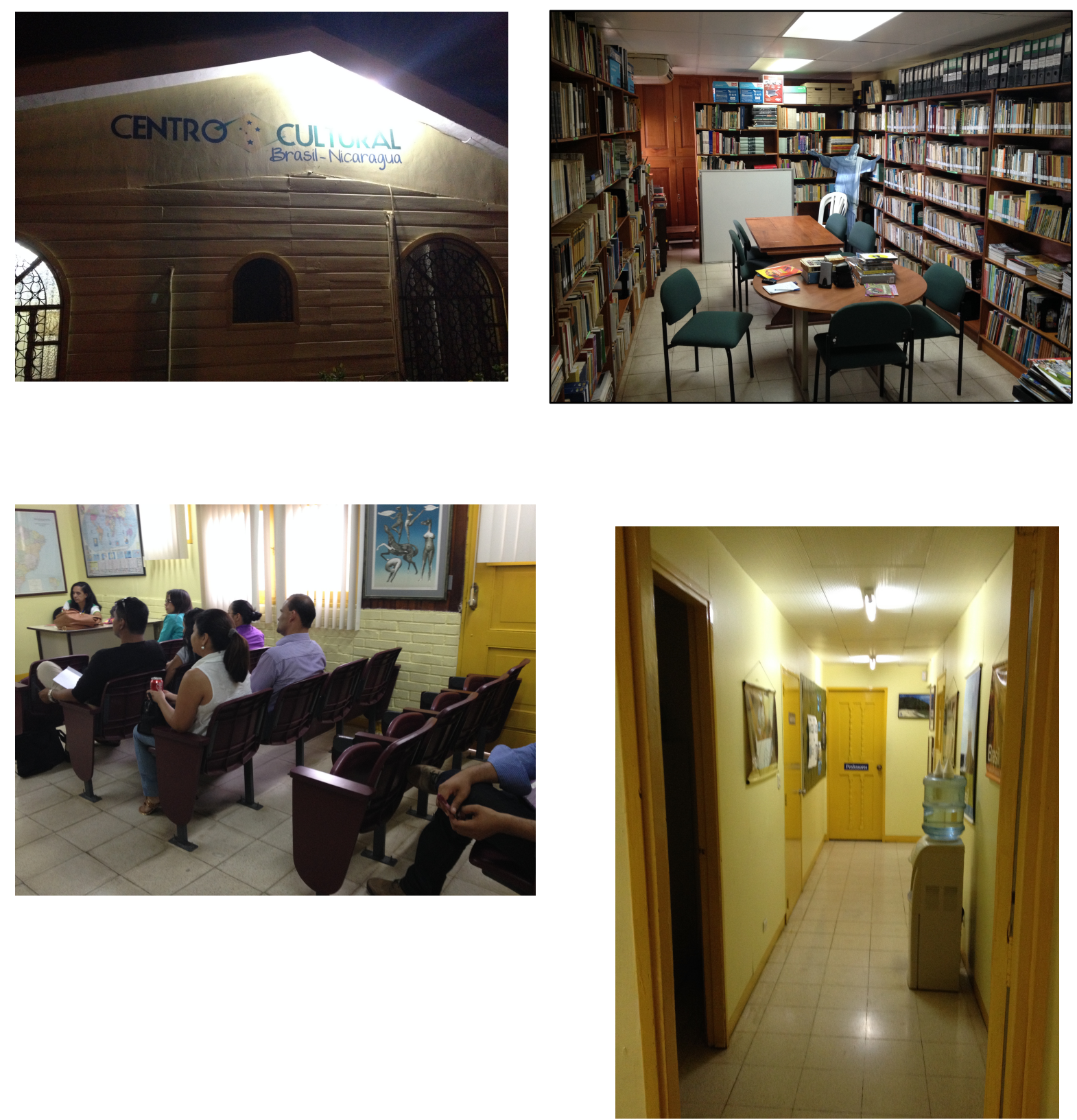

O Centro Cultural Brasil-Nicarágua conta com uma ampla biblioteca e um auditório. O CCBN recebe, em média, 250 alunos por bimestre letivo.

Facebook: https://www.facebook.com/Centro-Cultural-Brasil-Nicarágua-312112483868/ Twitter: @CCBrasilNic

Endereço e contatos: Carretera Panamericana Sur Km 7 3/4 - Manágua, Nicarágua. Fone de contato: (505) 2265-3604 


\section{ANEXO G: FOTOGRAFIAS DA FUNDAÇÃO DE CULTURA, DIFUSÃO E ESTUDOS BRASILEIROS NA COSTA RICA}
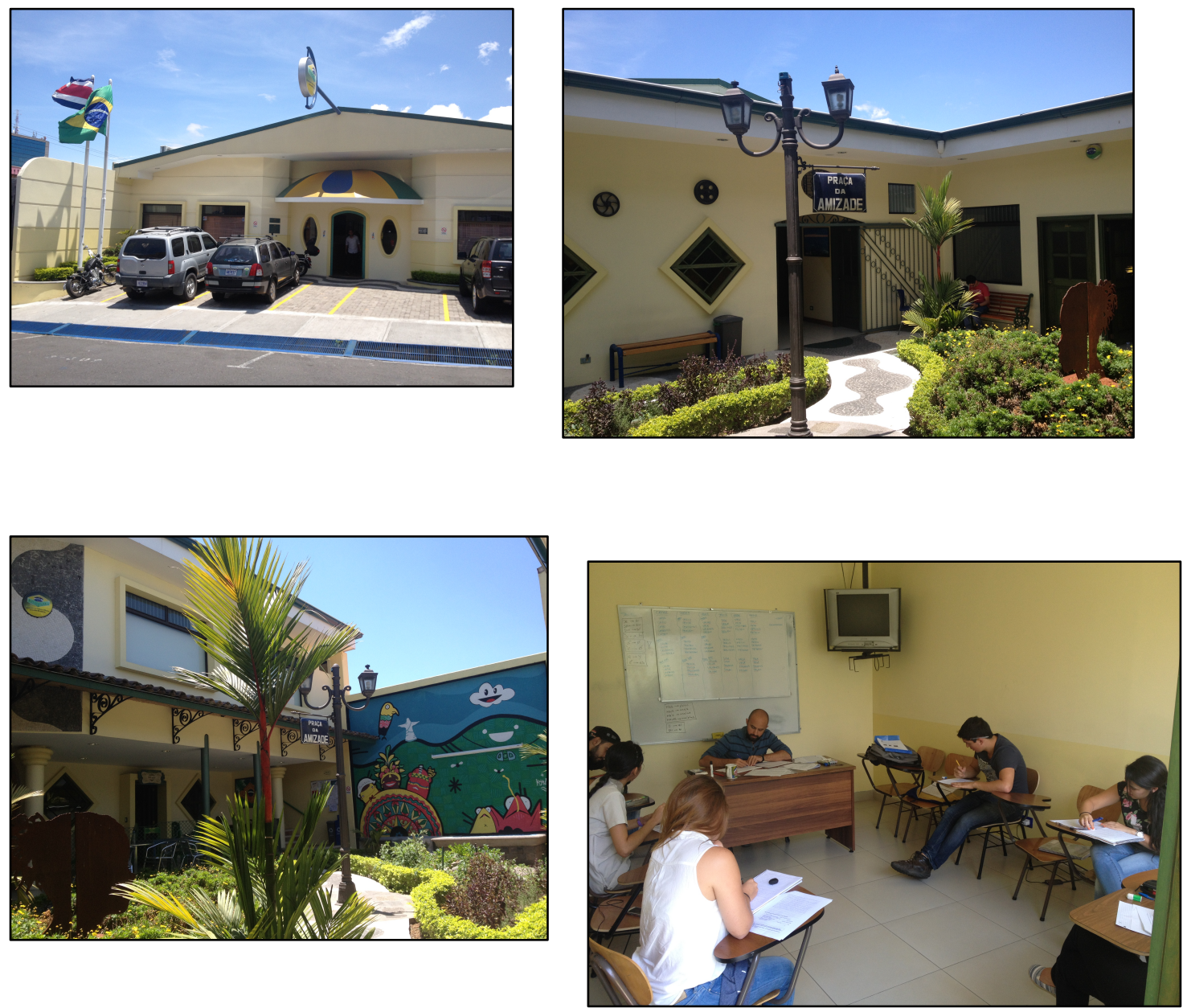

A FCDEB possui duas sedes na capital: San José e Santa Ana, separadas por uma distância de $15 \mathrm{~km}$. Dos três países visitados, a FCDEB é o centro de ensino de língua portuguesa que tem mais volume alunos em cada período letivo, ultrapassando os 1000 alunos por bimestre.

Website: http://fcdeb.com

Endereço e contatos: San José: de la Sala Garbo 100 este y 50 sur | Sede Santa Ana: de la Cruz Roja 150 oeste y 125 sur. Fone de contato: (506) 2222-5753 e (506) 2282-6057

Facebook: https://www.facebook.com/CentroDeEstudiosBrasilenos

Twitter:@fcdebcr

Youtube: https://www.youtube.com/channel/UCcn2N75irDpXkDZ7X6VdFVw 
ANEXO H: EMPREGOS QUE EXIGEM DOMÍNIO DO PORTUGUÊS

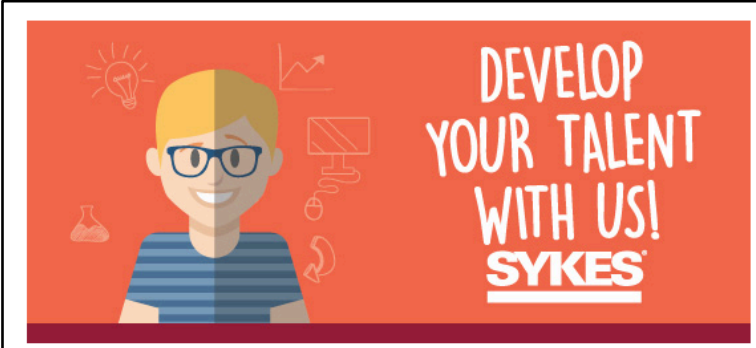

JOB REQUIREMENTS \& TECHNICAL SKILLS

( University degree or Advanced studies in computer engineer. systems engineer or related.(desired)

(2) Bilingual: Spanish, English proficiency.

Anúncio da empresa

( Trilingual: Portuguese/English/Spanish proficiency

Sykes Costa Rica

(2) Schedule Flexibility.

(2) High School Diploma.

( Data analysis capacity

( Excellent time management.

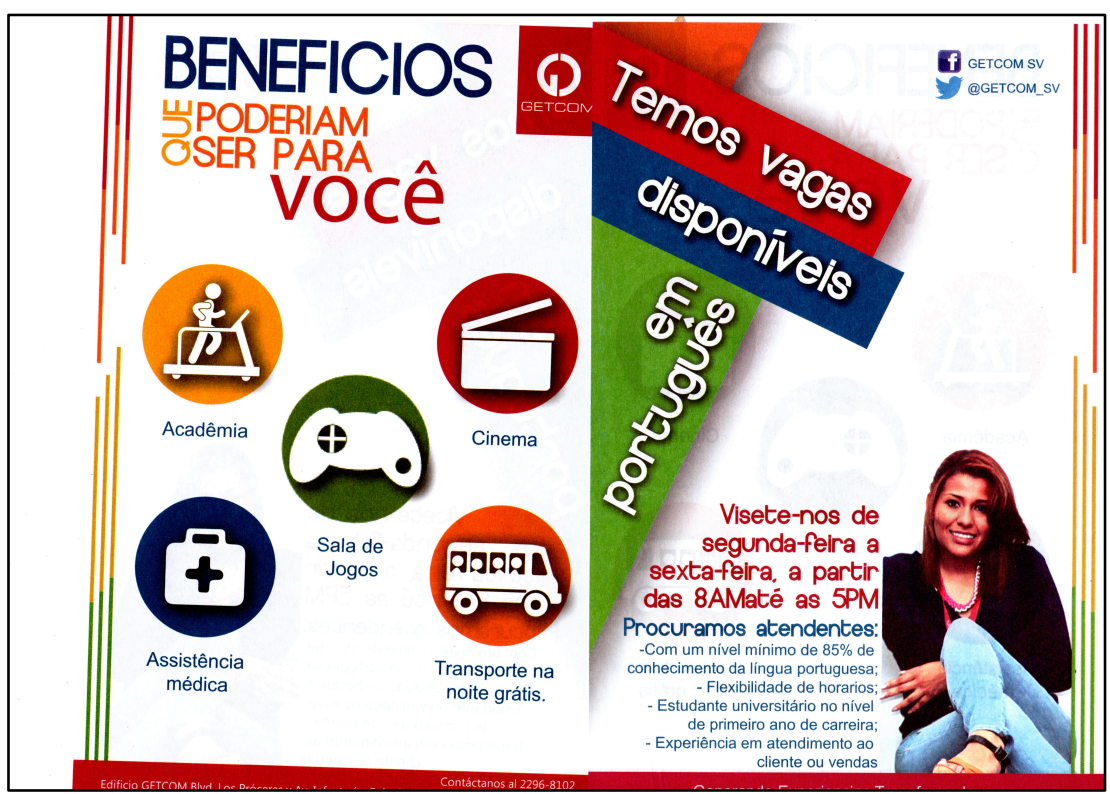

\section{OPORTUNIDAD DE EMPLEO}

El Liceo Prof. Luis Alfonso Pino solicita:

Profesor del idioma portugués para el siguiente horario, de 7:00am a 12:30m Las clases serán impartidas para alumnos de 2 a 6 años de edad.

Mayor información al Teléfono 2286-9420 con Roxana de Pino (Directora) o Karla Saenz (Secretaria) O escribe al siguiente correo electrónico roxanadepino@hotmail.com

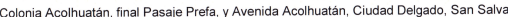

Anúncio de contratação de professor e agentes de call center em El Salvador 